\title{
الهشاركة|لانتخابية للمرأة|الهصرية 190V-19YT
}

$$
\text { الدكتور/ نبيل رياض عبد المولى عابدين }
$$




\section{المشاركة الانتخابية للمرأة المصرية \\ 190V - 19rr}

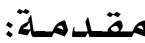

تُعد قضية المشاركة الانتخابية للمرأة من القضايا التى احتلت حيزاً لا بأس

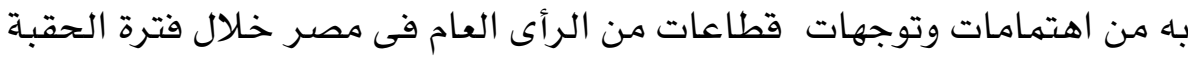

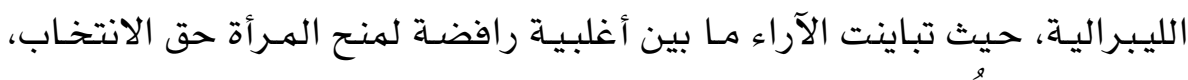
وما بين أقلية تنادى بمنحها هذا الحق.

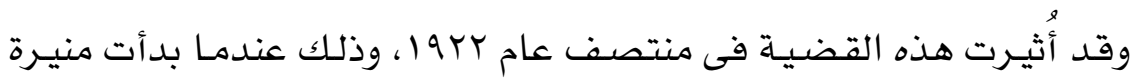

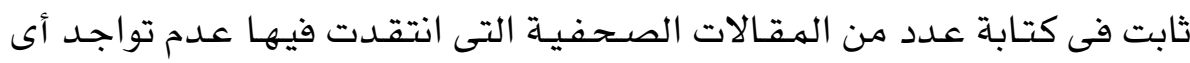

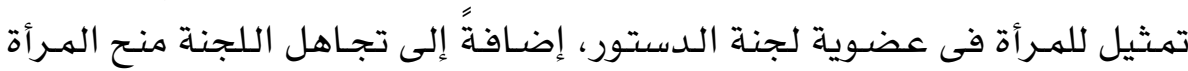

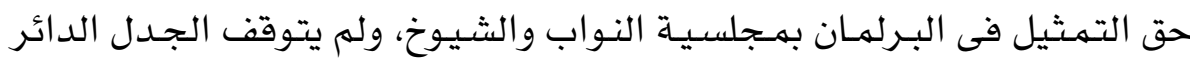

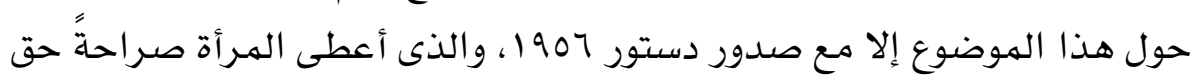
المشاركة السياسية، والتى يدخل تحتها حق المشاركة في الهيئات النيابية. إذ تتناول الدراسـة عدة محاور رئيسيـة: موقف الدستور من قضية انتخـاب

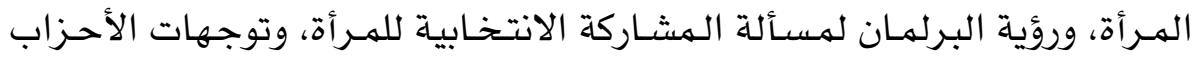

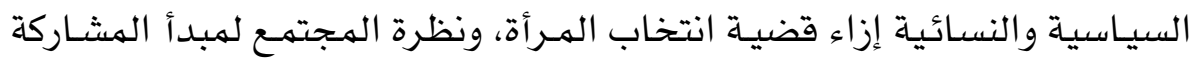

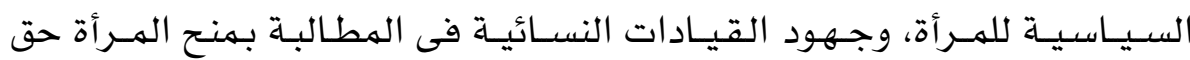

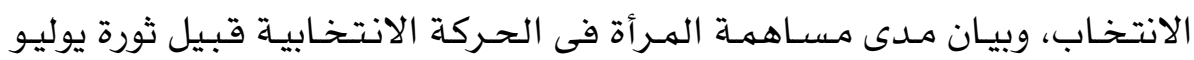

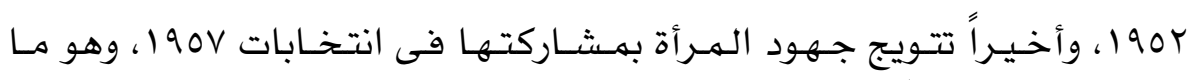
سنعرض له تفصيلاً. • موقف الدستور من قضية انتخاب المرأة:

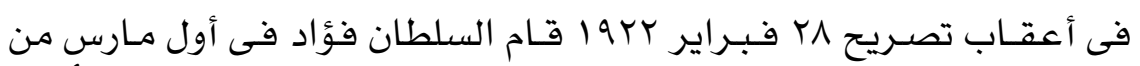

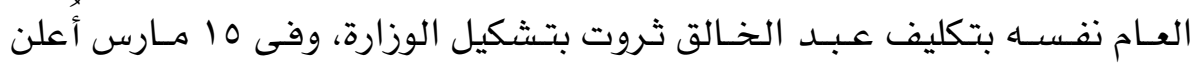

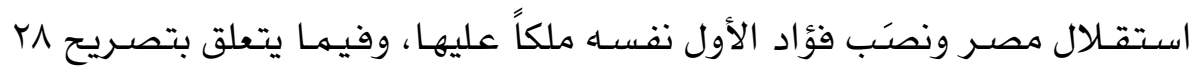




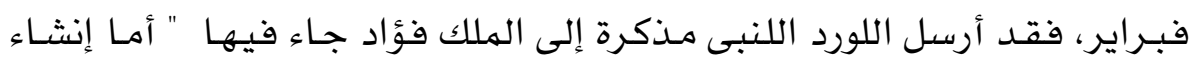

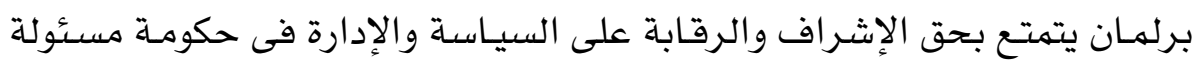

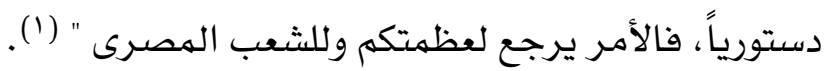

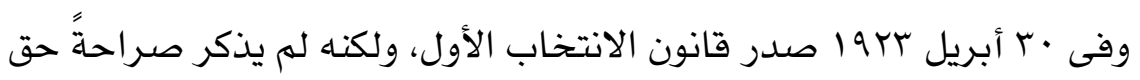

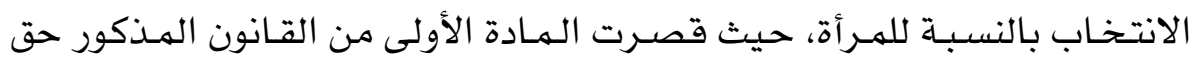

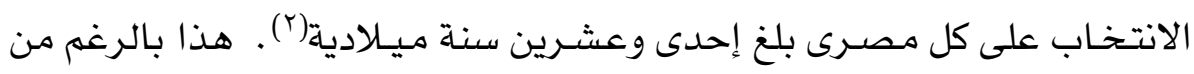

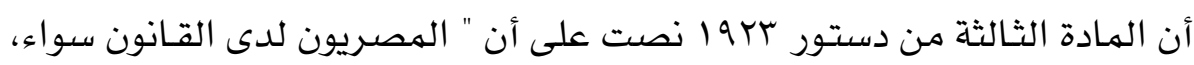

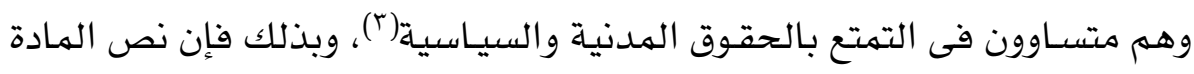

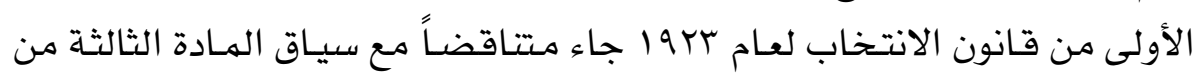
الدستور.

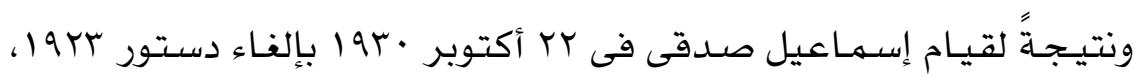

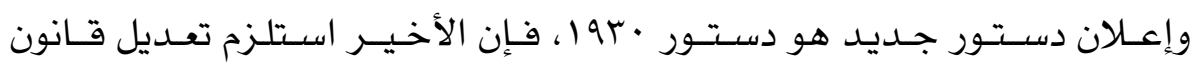

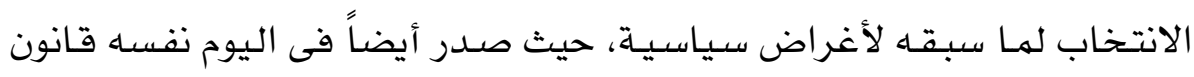

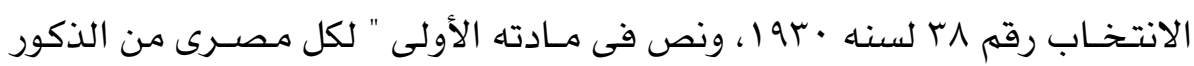

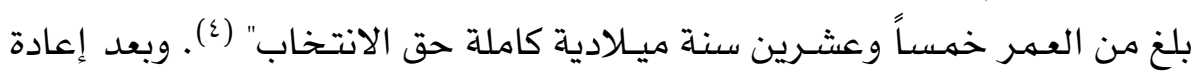

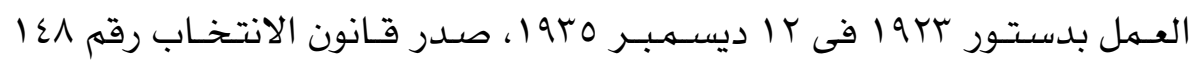

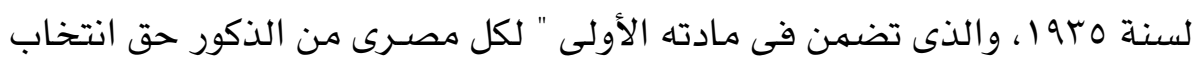
أعضاء مجلس النواب متى بلغ إحدى وعشرين سنة ميلادية كاملة ... " (0).

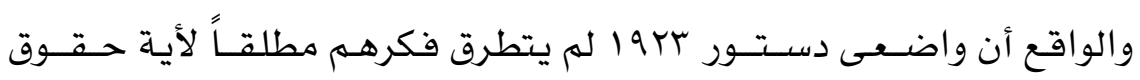

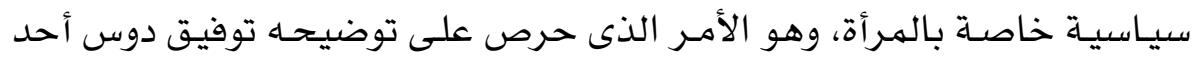

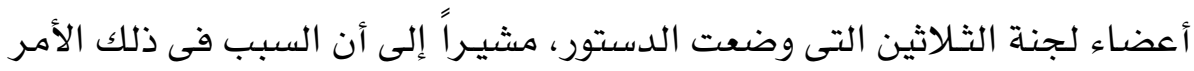

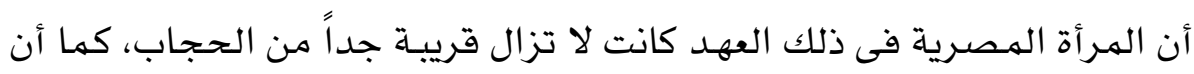

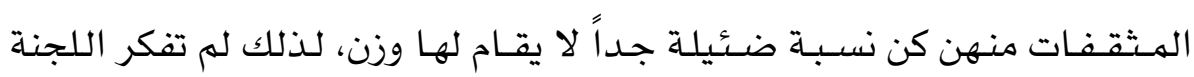

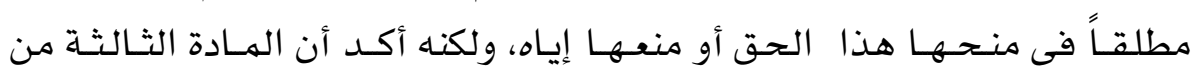


الدستور لا تؤدى إلى حرمان الهرأة من استعهمال هذا الحق (†). وعندمـا تم حل مجلس النواب في ع ب مـارس 190Y 190 وتعطيل جلسـات مـجلس

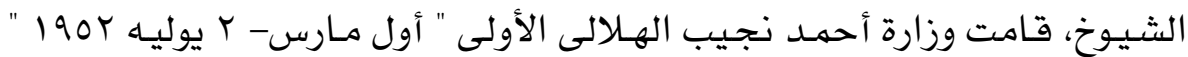
بتشكيل لجنة لدراسـة قانون الانتخـاب وإمكانيـة إدخـال بعض التعـديـلات عليـه،

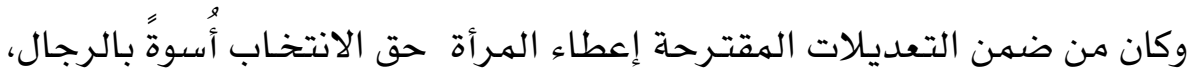

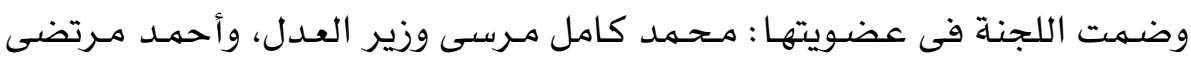

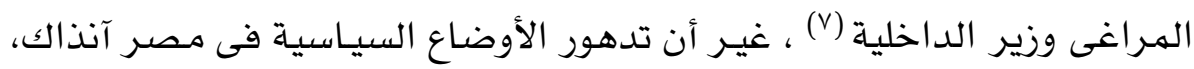

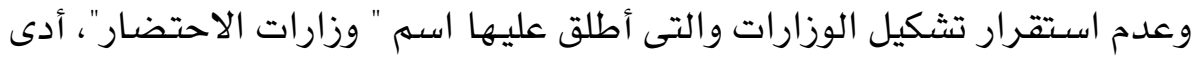

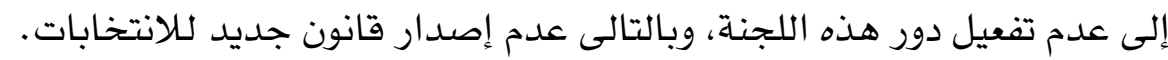

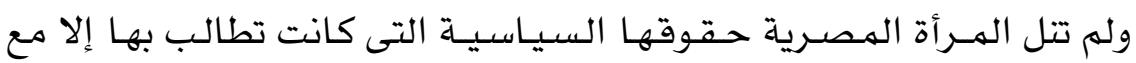

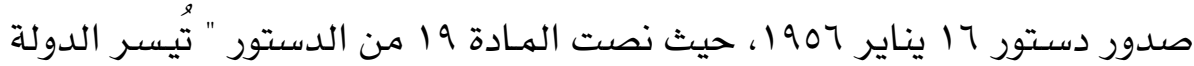

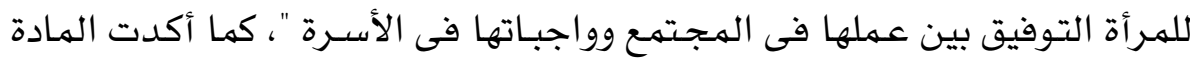

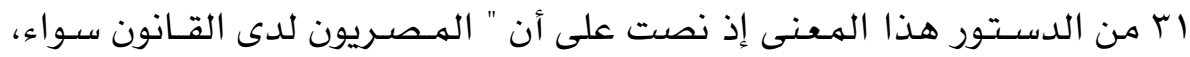

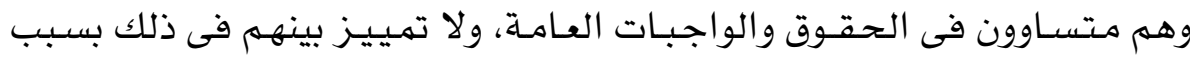

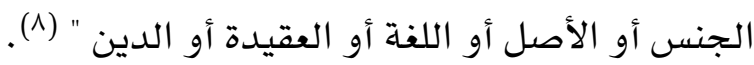
وإزاء هذه التوجهات الجـديدة فى دستور 1907، صدر فى ب مـارس من العام

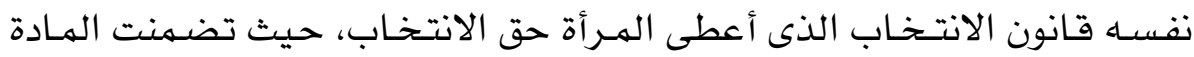

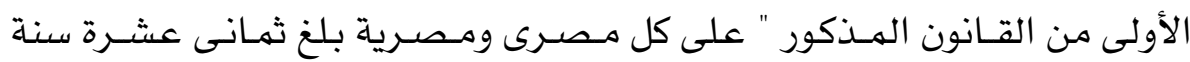

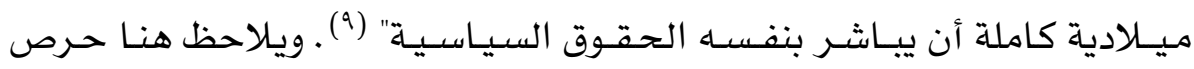

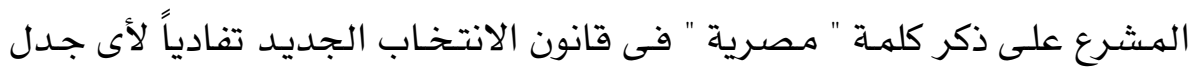

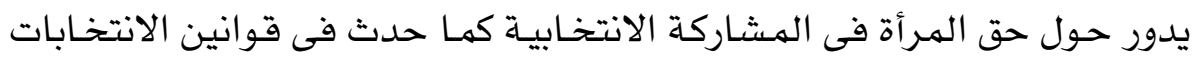

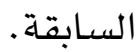

ولهم يشــأ القـانون الجـديد أن يُلـزم الهـرأة بـحق الانتـخـاب، وإنـــا جـعله أمـراً

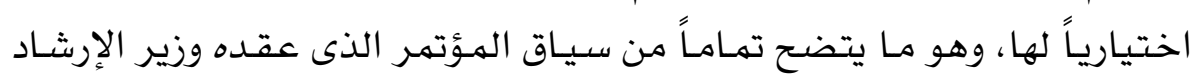


القومى فتحى رضوان فى ع مارس 1907 ، حيث أشـار إلى أهمية أن تتقدم المرأة

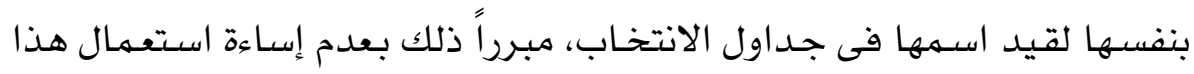

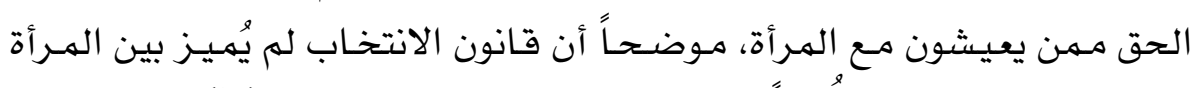

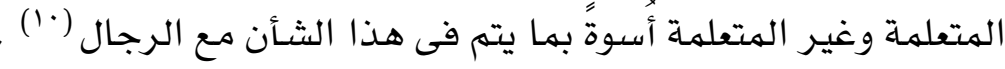
ويتبيـن من ذلك أنه خلال فتـرة الدراسـة صدرت ثلاثة دسـاتيـر، وكان دستور

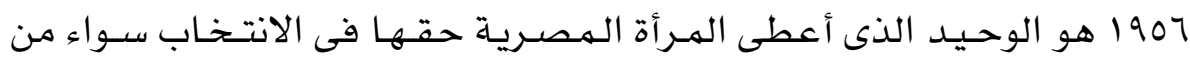

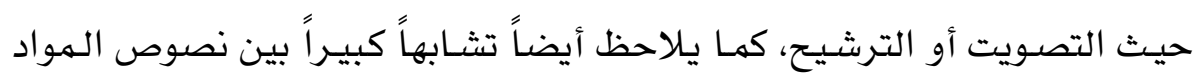

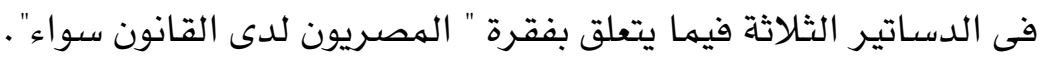
• رؤية البرلمان لمسألة المشاركة الانتخابية للمرأة:

بمراجعة الفترة الممتدة ما بين عامى عب9 او 90 190، ومن خلال قراءة العديد

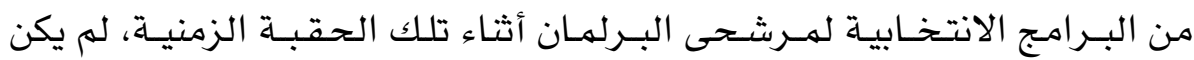

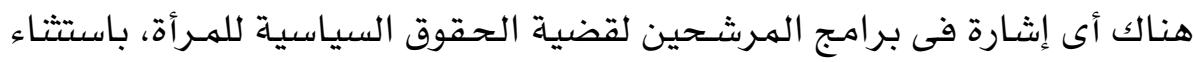

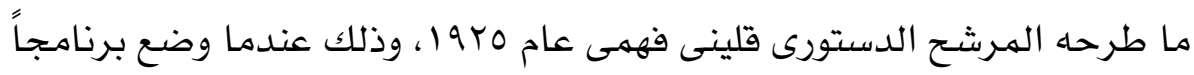

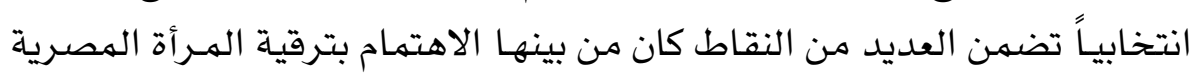

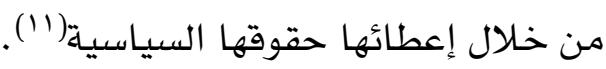

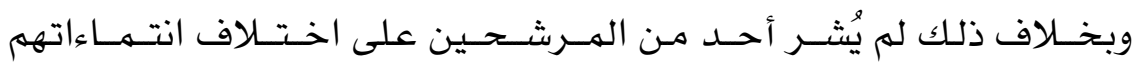

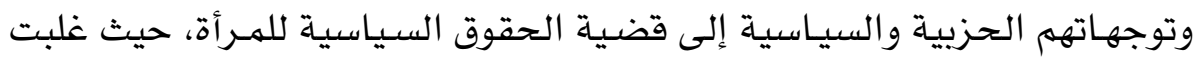

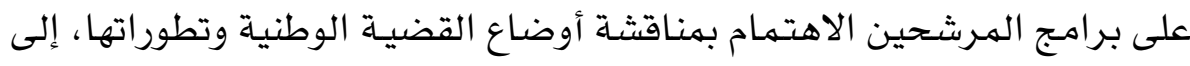

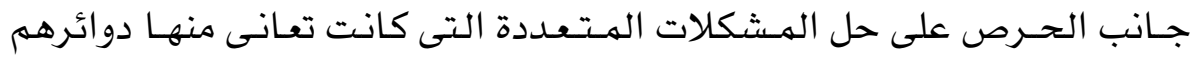

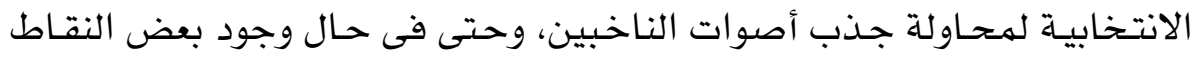

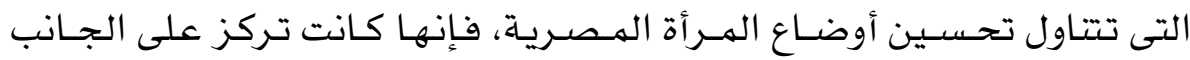

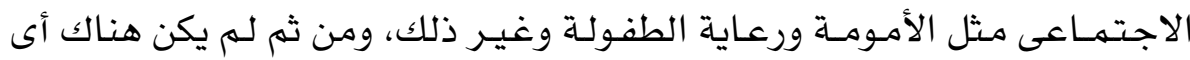

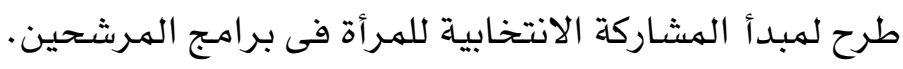
أما فى داخل البرلمان فإنها للم يتم عرض هذه القضيـة للمناقشـة إلا فى عام 
عـ9 1، وذلك عندما قدم عضو مجلس النواب زهير صبرى اقتراحاً بتعديل قانون

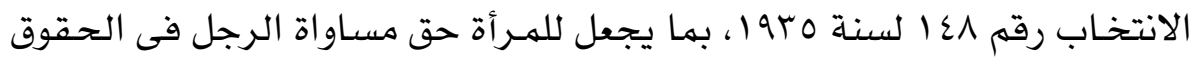

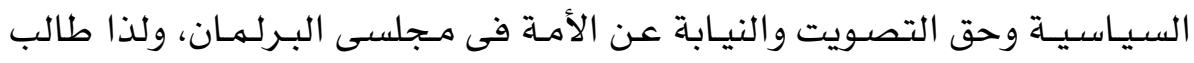

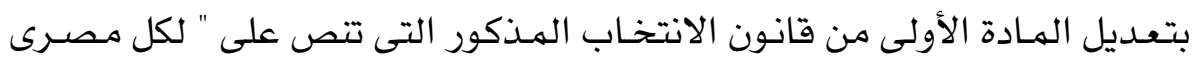

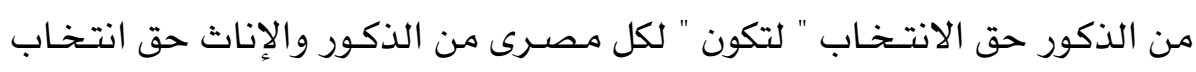

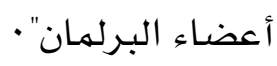

وأكد زهيـر صبـرى أحقيـة المـرأة فى الانتخـاب ومشـاركتها للرجل فى هذا

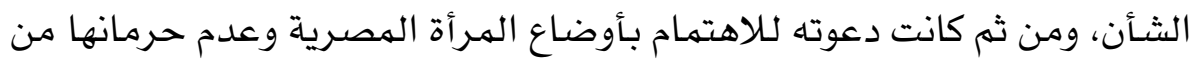

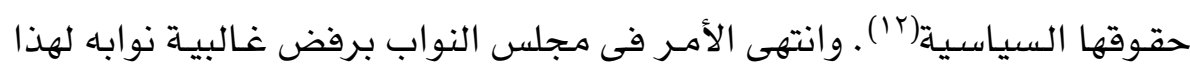
الاقتراح.

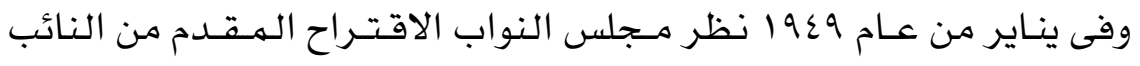

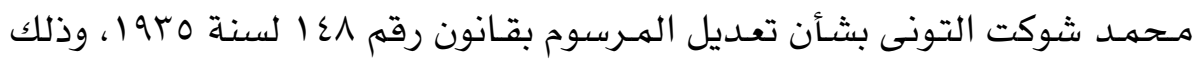

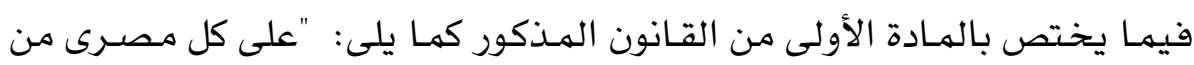

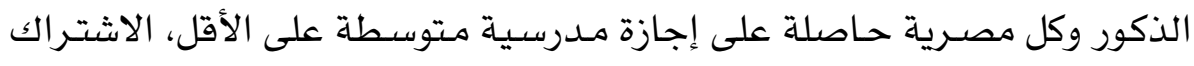

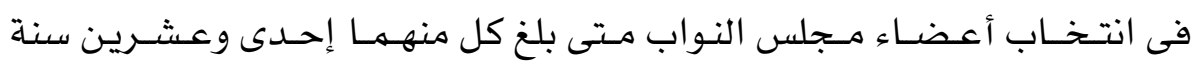

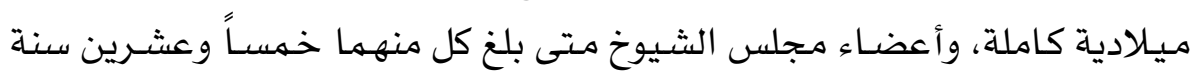

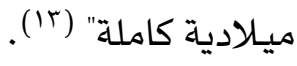

ورغم مـوافـقــة لجنـة الاقتــراحـات والعـرائض على قبــول مشــروع القـانون

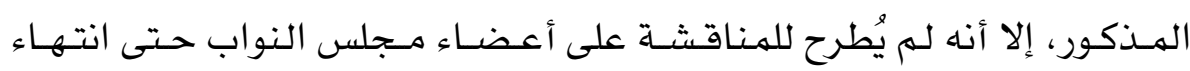

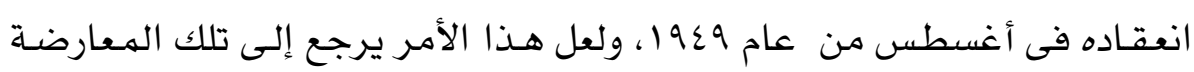

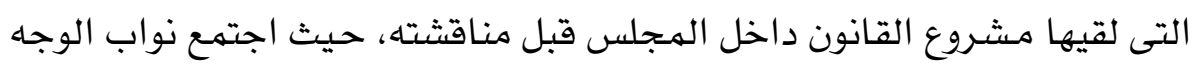

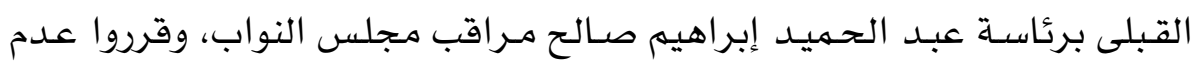

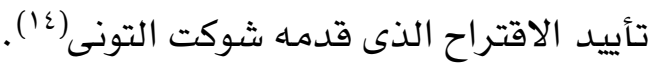

وفى أعقـاب اقتحـام قيادات الحركة النسائية للبرلمان فى 19 فبراير 1901 ، 
وقيامهم بتقــيم عـريضـتين لـرئيسى مـجلسى النواب والشيوخ بشـأن منح الهـرأة

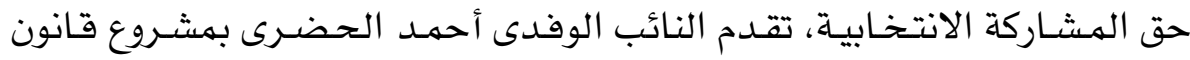

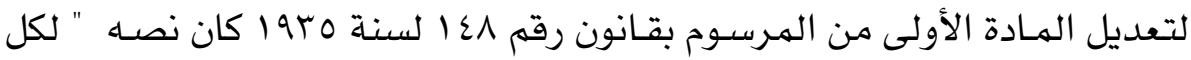

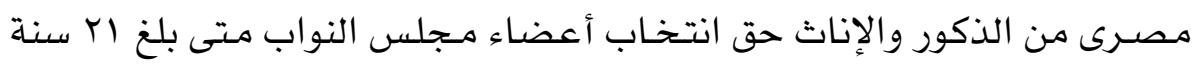
وأعضاء مجلس الشيوخ متى بلغ من سنة الإنة " (10).

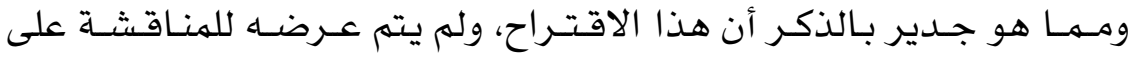

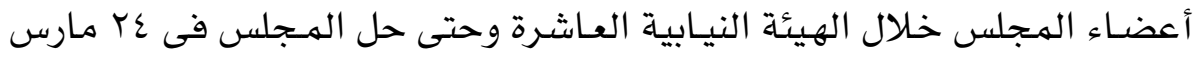

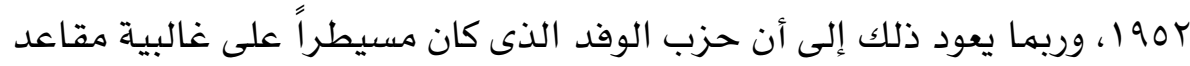

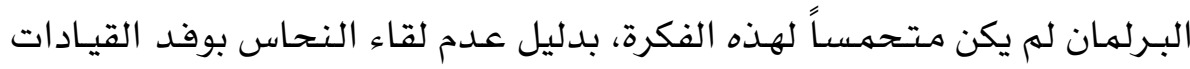

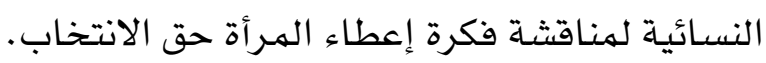

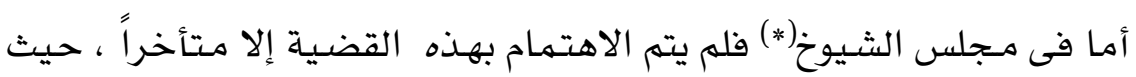

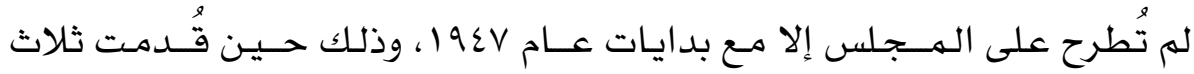
اقتـراحـات بهشـروعات قوانين دارت كلها حـول تعـديل الهـادة الأولى مـن قانون

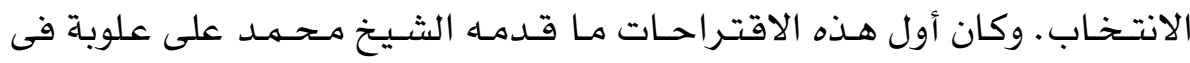
ديسمبر 19 197، وذلك فى مشروع قانونه الخاص بتعديل المادة الأولى من قانون

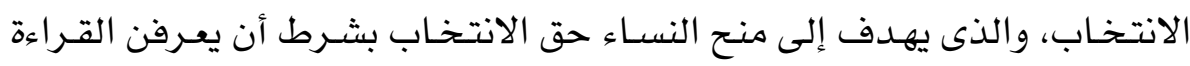
والكتابة. وفى يناير مـن عـام 9 ا قدم الشيخ أحمـد رمـزى اقتراحـاً بمشـروع قانون

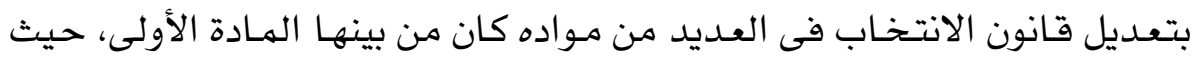

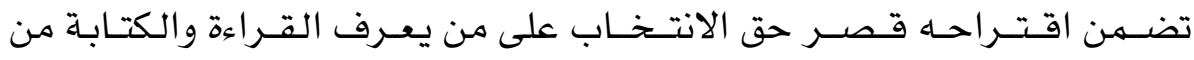

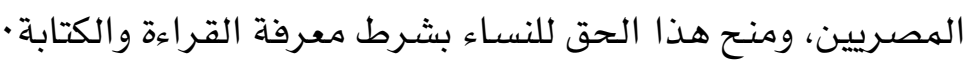

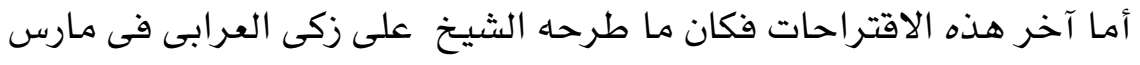

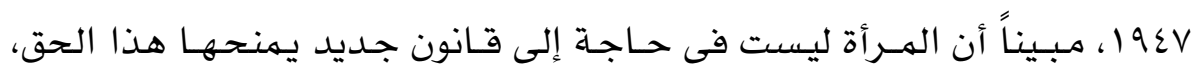

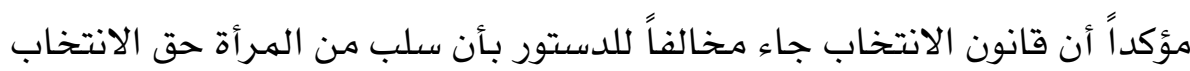


الهخول لها بمقتضى المادة الثالثة من الدستور، ولذا طالب بتعديل المادة الأولى الهـ

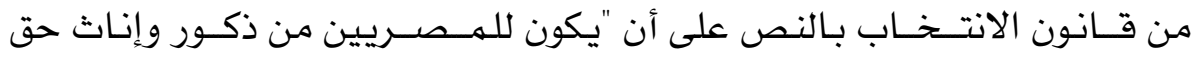
الانتخاب" حتى لا تظل هذه المادة غير دستورية (17).

ورغم قيـام مـجلس الشيـوخ بإحـالة الاقتـراحـات الثـلاثة إلى لجنـة الشـــون

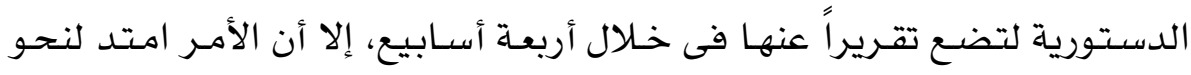

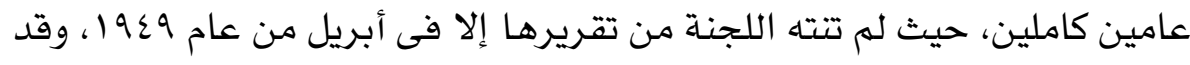

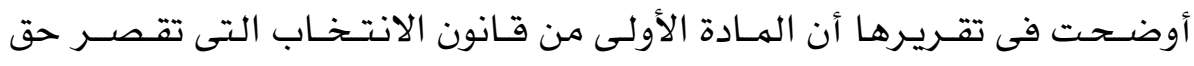

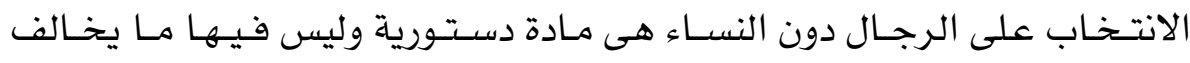

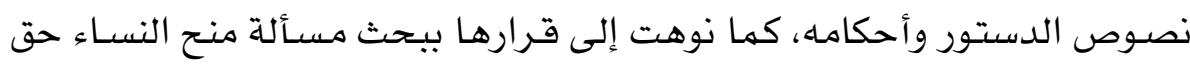
الانتخاب من الوجهة الموضوعية (IV). وتجــدر الإشـارة إلى أن قـرار لجنـة الثــــون الدســـورية بعـدم تعـديل الهـادة

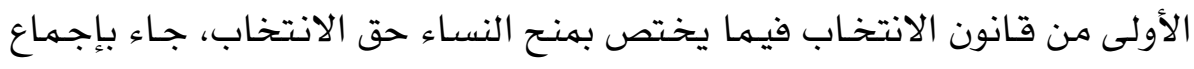
أراء أعضاء اللجنة، كما وافقت الحكومة بلسان مهثليها الذين حضروا اجتماعات

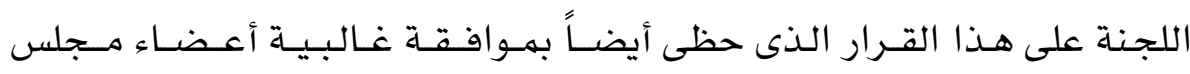
الشيوخ(1^)

ومن الواضح تماماً أن الرأى العام فى مصر لهم يكن مهُيـاً بدرجة كافيـة لتقبل

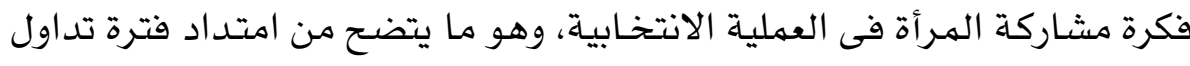

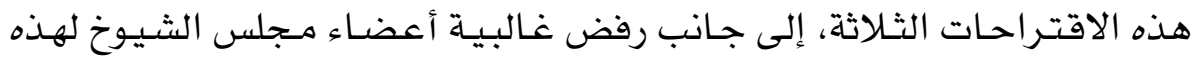

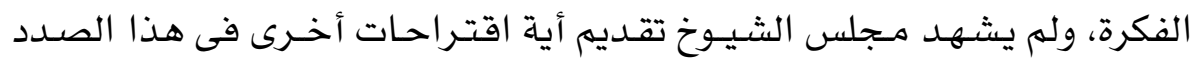

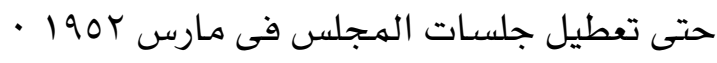
وثمة ملاحظة أخيرة على رؤية البرلمان لمسـألة المشاركة الانتخابية للمرأة، حيث إن جـيع خطب العرش التى ألقيت في افتتاح البرلـهان في هيئاته النيابية

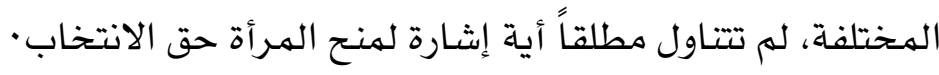




\section{• توجهات الأحزاب السياسية والنسائية إزاء قضية انتخاب المرأة:}

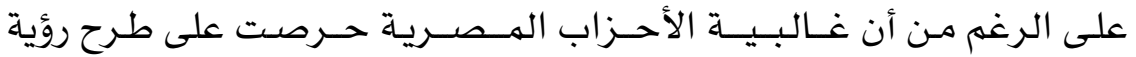

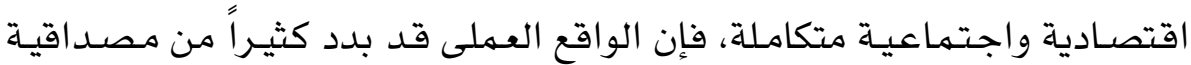

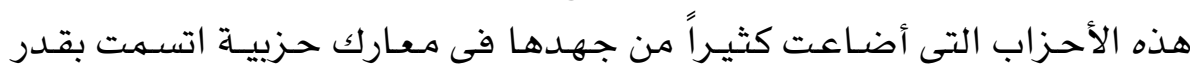

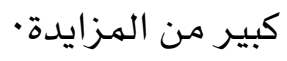

ويُعـد عـام بr 19 البـداية الحـقيقـيـة لاهتهـام الأحـزاب الهـصـرية بالقــايا الاجتماعيـة والاقتصادية، حيث قبلت غالبية الأحزاب العمل بدستور بـ 19 ، وكان هذا الأمـر فـرصــة لحـزب الوفـد لكى يعـيـد صـيـاغـة برنامـجـهـ بهـا يتــاسب والمتغيرات التى ألمت بالقضية الهصرية، وقدم سعد زغلول لأول مرة ما أسـماه "بروجـرام " الحـزب، حيث تطرق فيـه إلى الاهتمـام بالتعليم ، وتحسسين الأحسوال

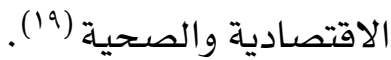
وتجدر الإشـارة إلى أن فكرة تكوين الوفد المصرى قد صاحبها فكرة إشتراك العنصـر النســائى فى هـذه المنظهـة الوطنيـة الجــديدة، وذلك لإتهـام نجــاح

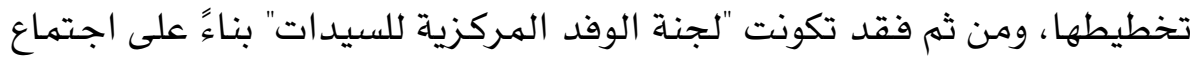

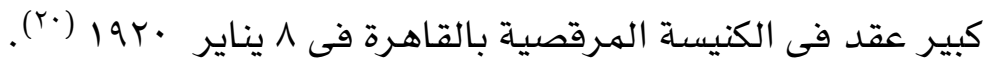
إلا أن الوفد له يعمل على وضع تشريع يحقق مصالح المرأة ويصون حقوقها، بل له تكن قضية المرأة من بين القضـايا التى عنى بها فى الوقت الذى كانت فيه

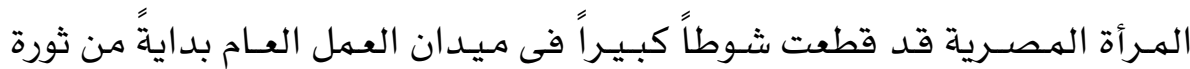

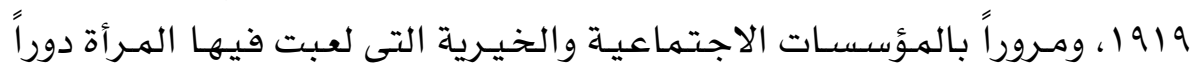

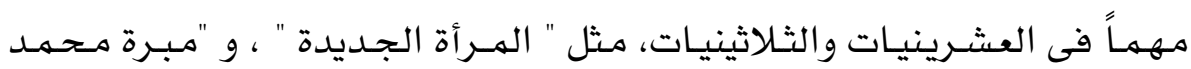

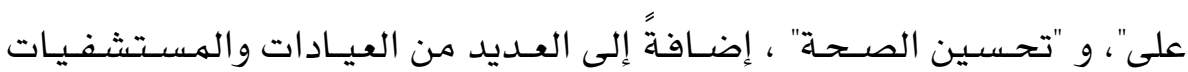

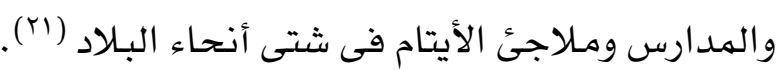

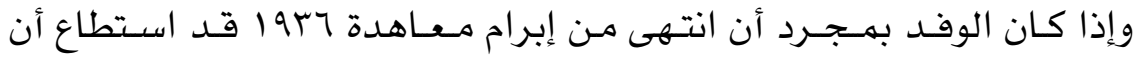
يتلمس مصـالح الطبـــات الهـهنيـة الهـخـلفـة، إلا أن طبيـعـة الصـراع بيـن القوى 
السياسـيـة انعكست بشكل واضتح على قضـايا التتميـة، إضـافةً إلى أن الانقـلابات

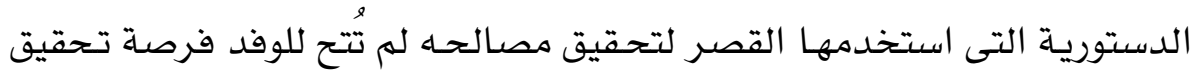

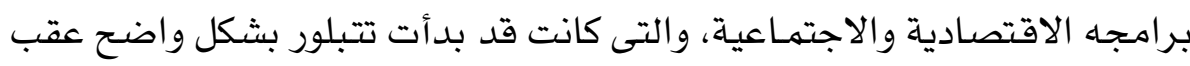
توقيع معاهدة 1947 (rr)

ومع ذلك فإن الوفد لهم يسع جاهداً لتفعيل المشـاركة السياسية للمرأة خاصةً

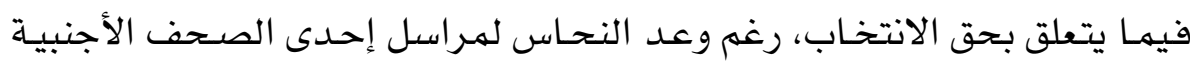

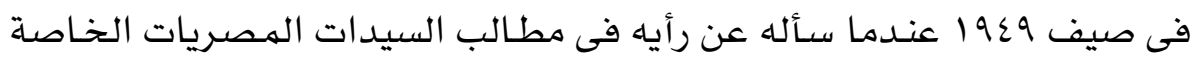

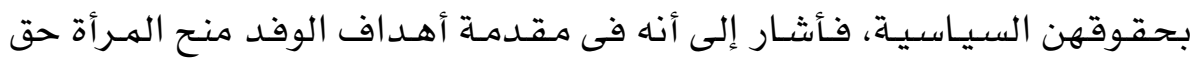

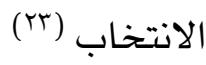

وفى حوار أجرتهاه صحيفة "الأهرام" مـع النحاس فى أغسطس من عام 199

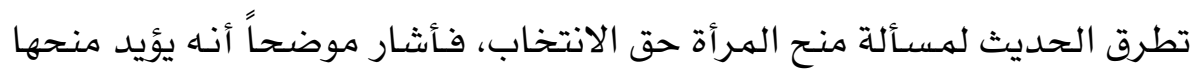

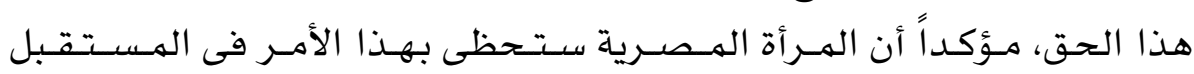

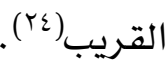

بيـد أن واقع الأمر يشير إلى قصور واضـح مـن جانب الوفـ فى تبنى الحقوق

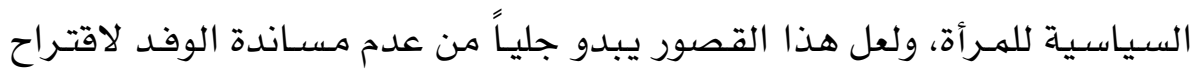

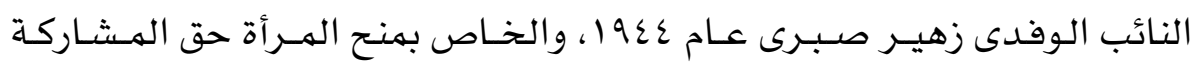
الانتخابية، فى الوقت الذى كان الوفد يستحوذ فيه على غـالبية مقاعداعد البـرلمان

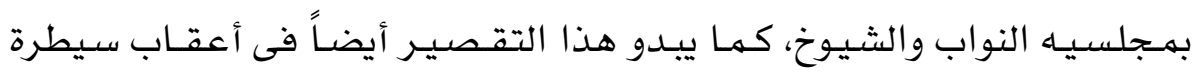

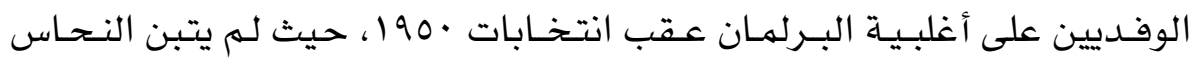

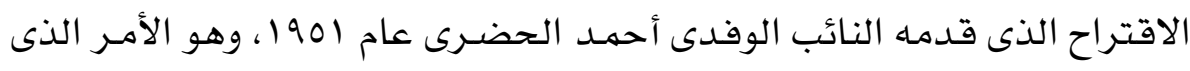

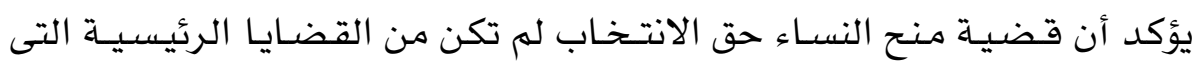
تشغل تفكير الوفد في هذه المرحلة من تاريخ مصنر.

وقد أدت الانثقاقات التى تعرض لها حزب الوفد إلى ظهور ثلاثة أحزاب

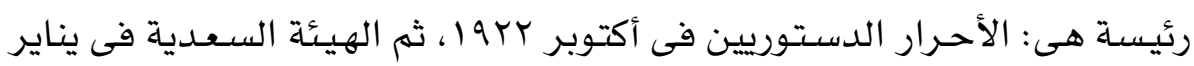


19r1، وأخيراً الكتلة الوفدية التى تأسست عـام بع19 بعد فصل مكرم عبيد من الوفد في يوليه من العام نقسهاه.

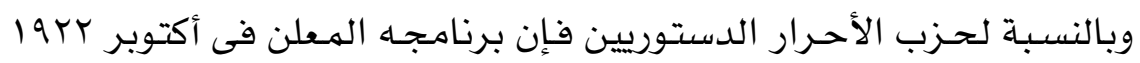

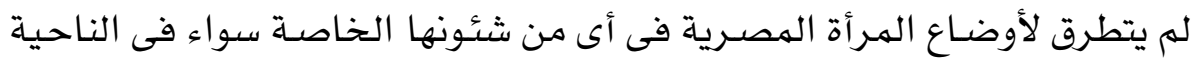

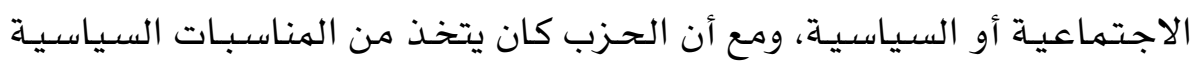

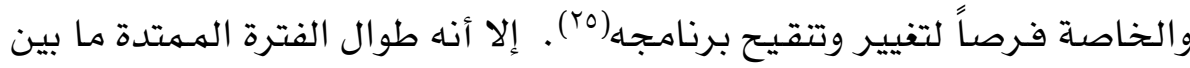

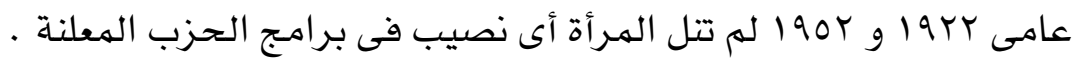

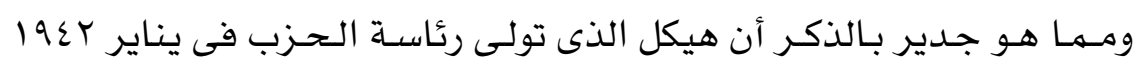

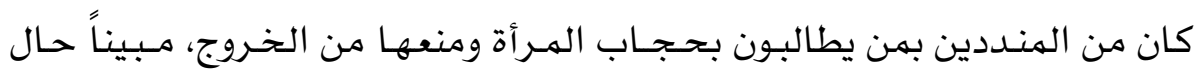

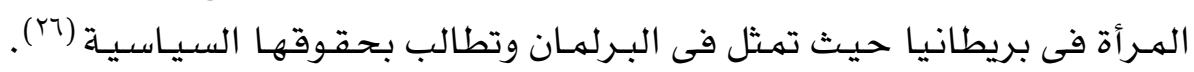

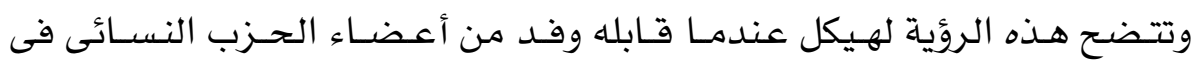

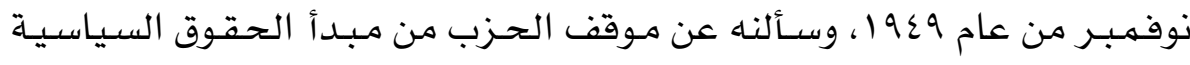

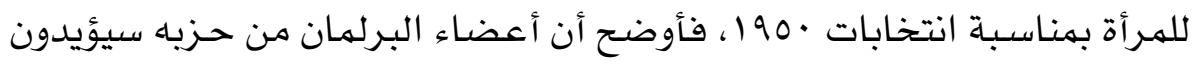

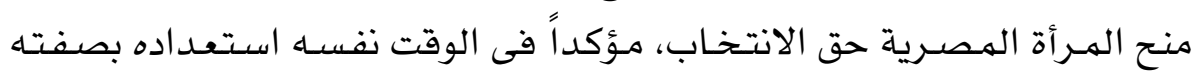

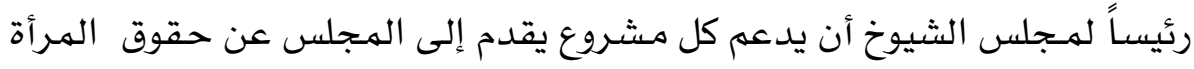
السياسية (TV) (TV)

أما الهيئة السعدية فقد تصدر برنامـجها ثلاثة مبادئ أسـاسية تمثلت فى فهم

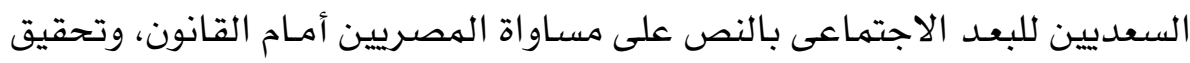

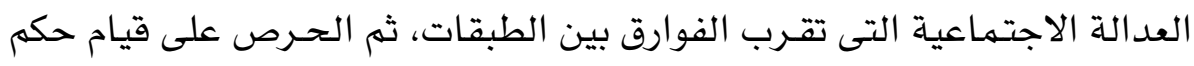

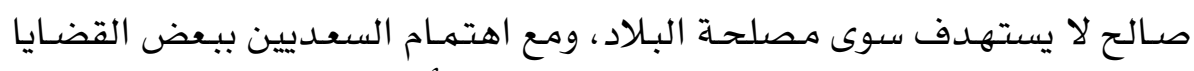

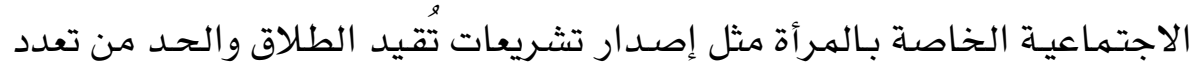

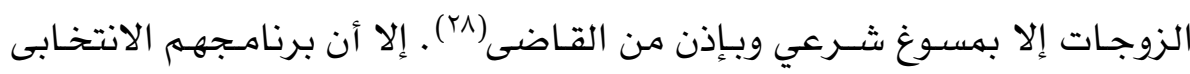

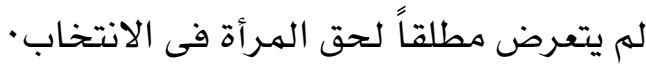
وتجــدر الإثــارة إلى أن النقـراشى أثناء توليـهـ لوزارته الثنانيـة (9 ديســـــر 


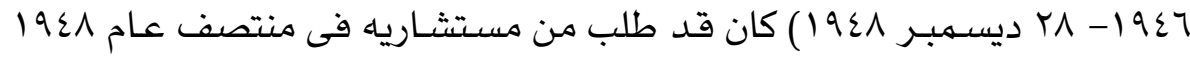

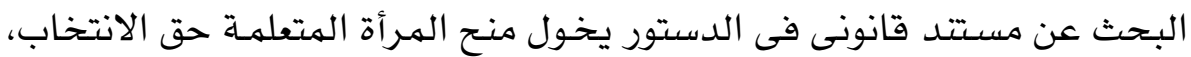

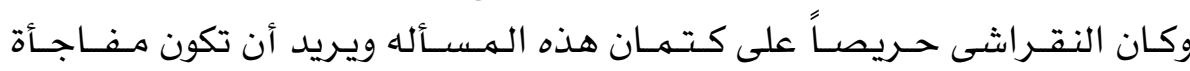

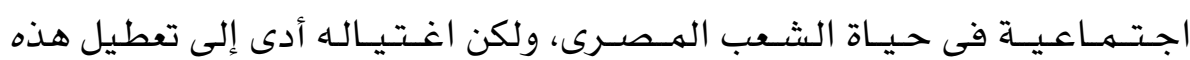

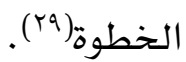

ويبـدو أن هذا التوجـه لدى النقـراشى كان أمراً خـاصاً بـه ولهم يكن رؤية عامـة

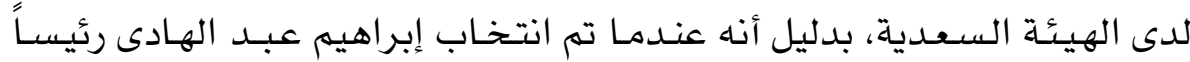

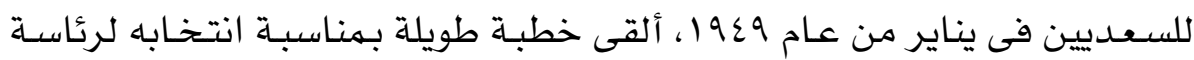

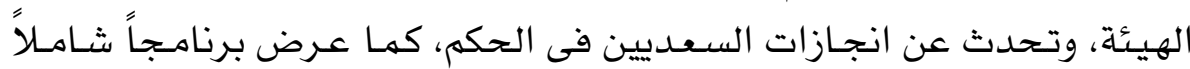

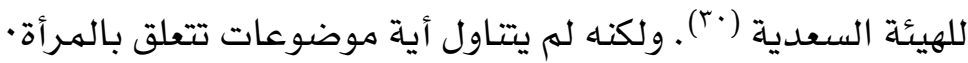
ولم يتطرق حزب الكتلة الوفدية فى برنامجها الانتخابى المعلن لأوضاع المرأة

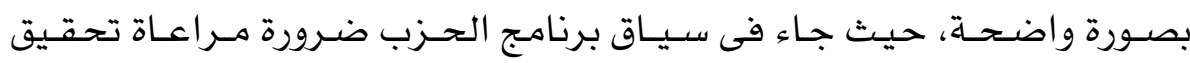

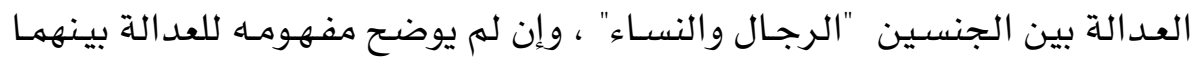

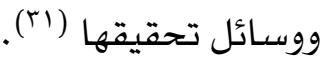

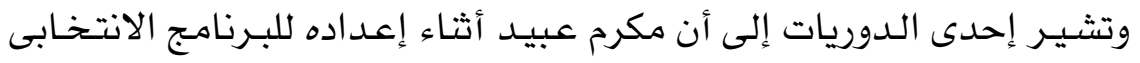

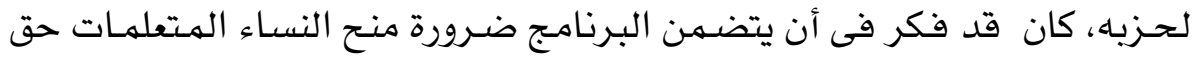

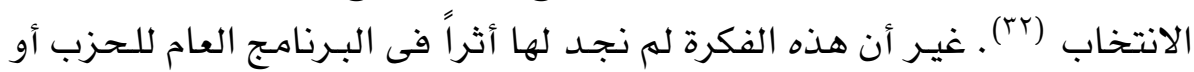

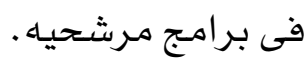

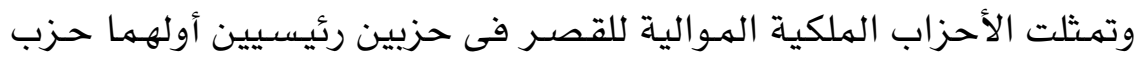

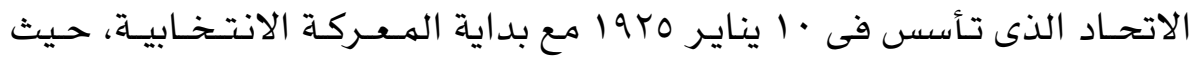

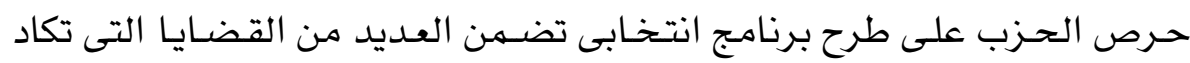

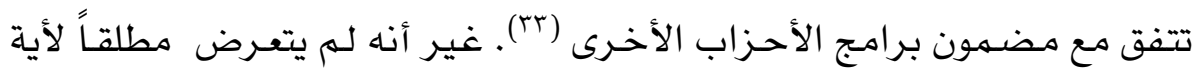

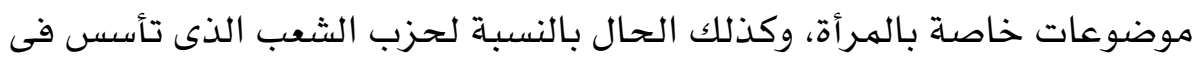

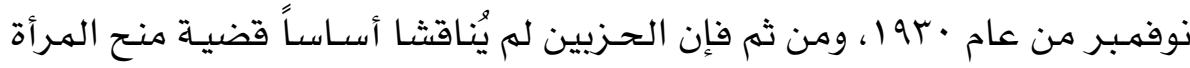
حق الانتخاب. 
ويأتى حزب العهـال الذى تأسس مع مطلع الثلاتينيات في مقـدمـة الأحـزاب

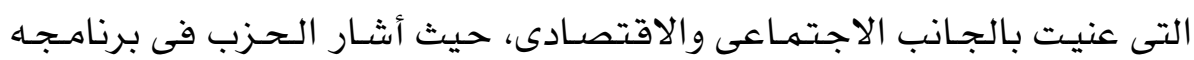

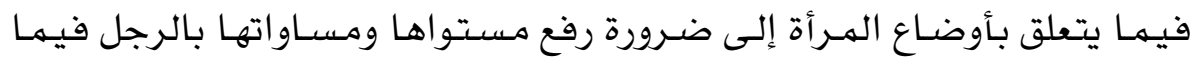

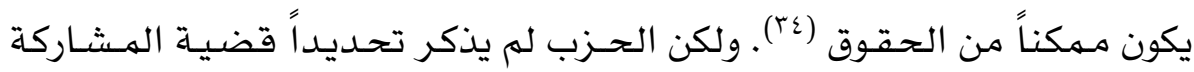
الانتخابية للمرأة.

وعندمـا تحولت جمعيـة مصر الفتاة إلى حزب سياسى فى ديسمبر من عام

1941، قـرر الحـزب خـوض معـركة انتخـابـات 1941، ولذا طالب بتعديل قـانون

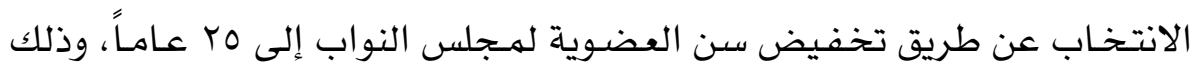

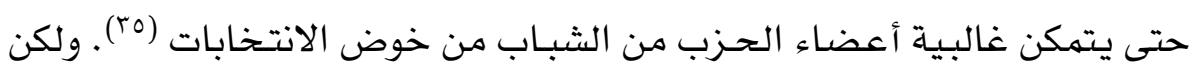

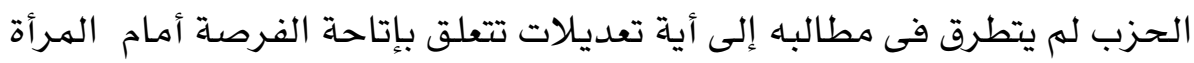

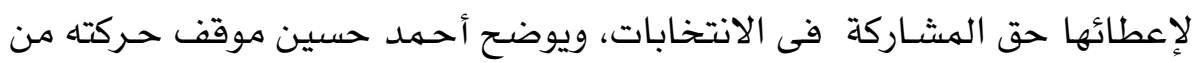

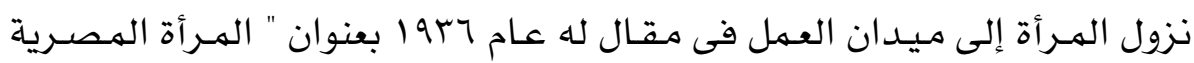

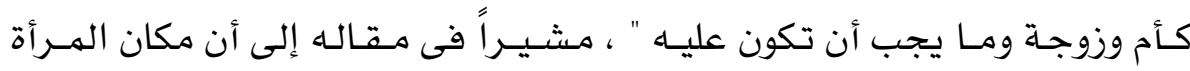

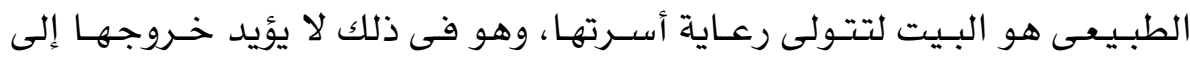

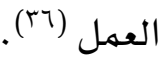
ومهما يؤكد هذا التوجـه لدى أحمد حسين أنه فى مؤتهـره الانتخابى الكبيـر

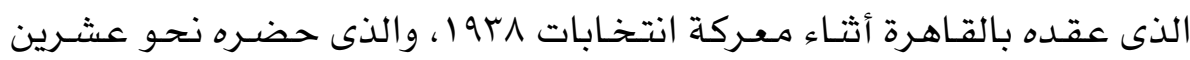

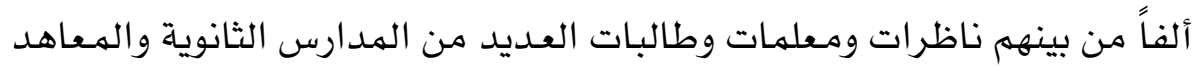

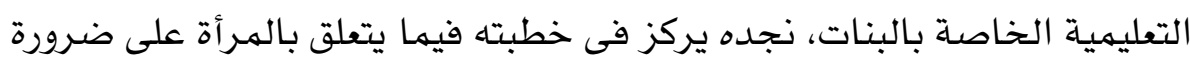

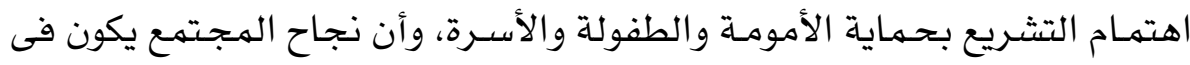
تخريج فتاة متعلمة لتكون أماً صالحة (rv). وبالإضـافة إلى ذلك فـإن البرنامج الانتخابى للحزب والذى تكون من ^ب بنداً

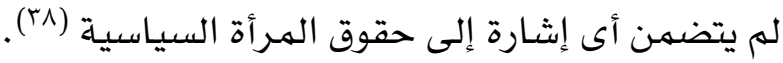
ومع تأكيد الحزب الهستمر على أهمية دور المرأة كأم وزوجة، فإنه للم يغفل 
أن هذه الوظيفـة الأسـاسية للمـرأة يجب ألا تحول دون تمتعها بحقوقها السياسية

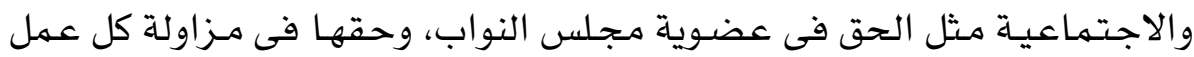

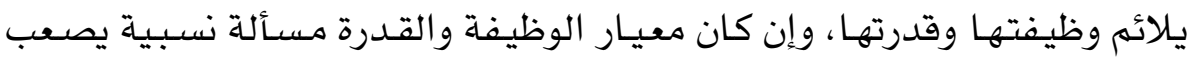
تحديدها بشكل مطلق (rq).

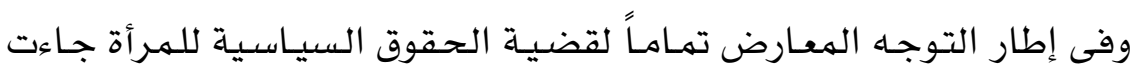

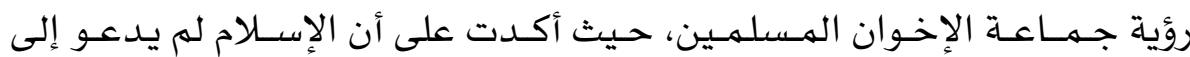

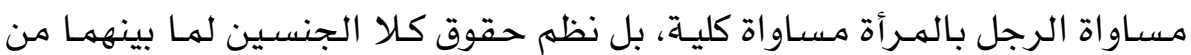

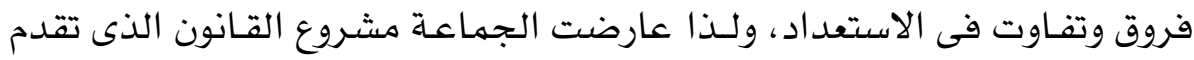

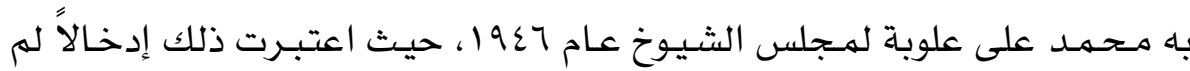

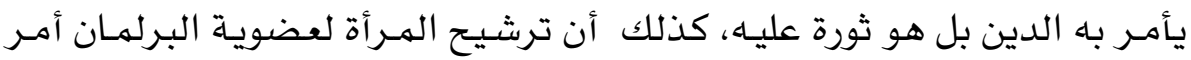

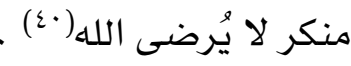
وأثناء الاستعـداد لانتخـابات عام •190، قرر العديد من النواب الهستقلين

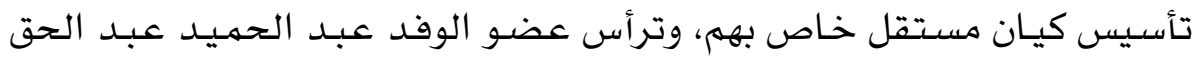

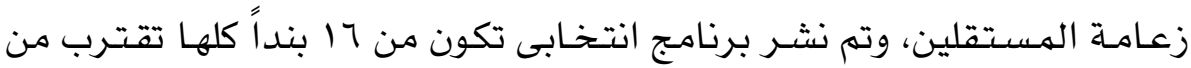

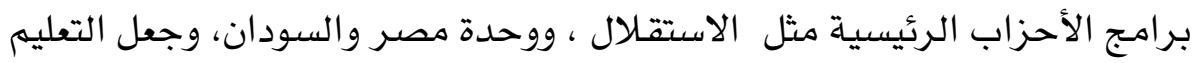

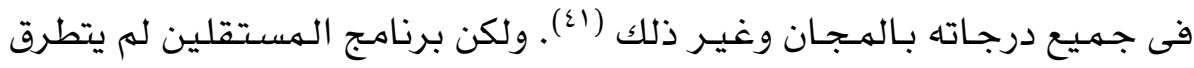

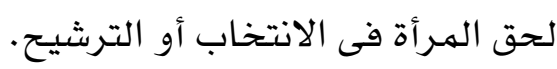
أهـا الهيئات النسـائيـة التى تتاولت فى برامجهها قضيـة الحقوق السيـياسيـة

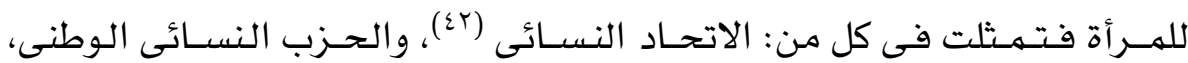

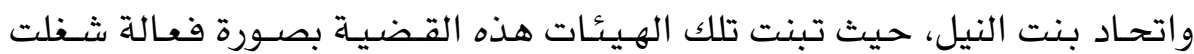
اهتمامات مؤسسيها بدرجة واضحة •

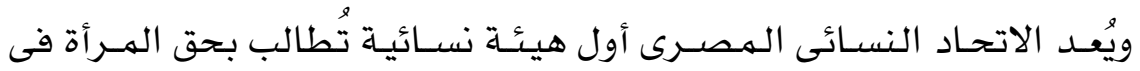

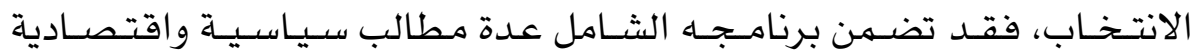

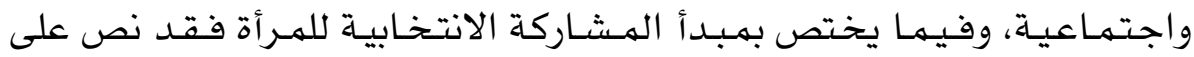


"تعديل قانون الانتخـاب بإشــراك النسـاء مـع الرجـال فى حق الانتخاب ولو بقيود

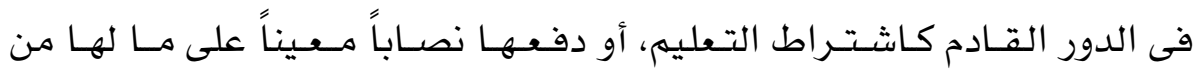

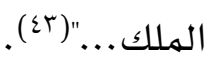

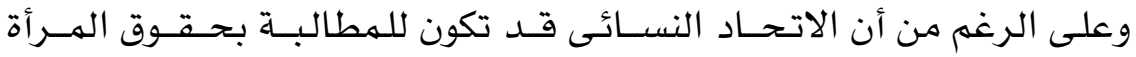

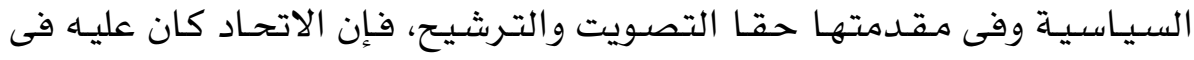

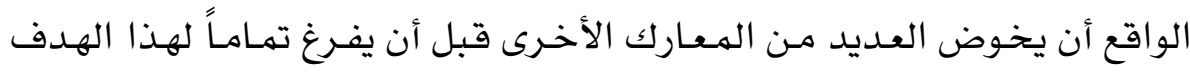

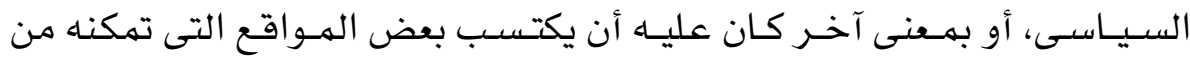

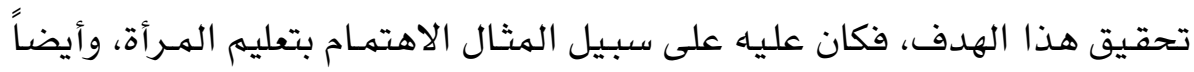

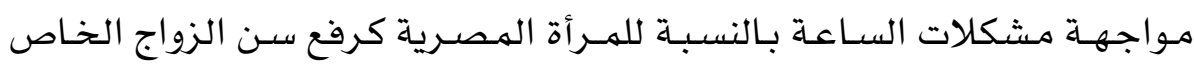

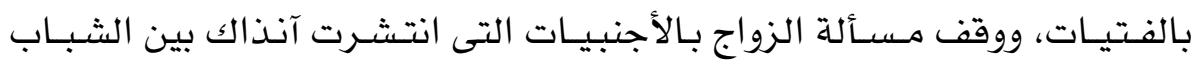
المتعلمين الذين كانوا يسافرون إلى أوربا طلباً للعلى (عء).

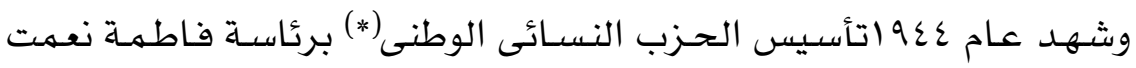

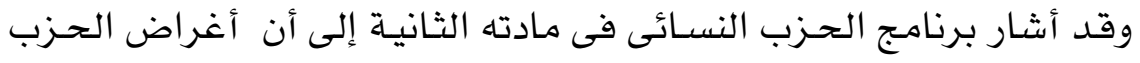

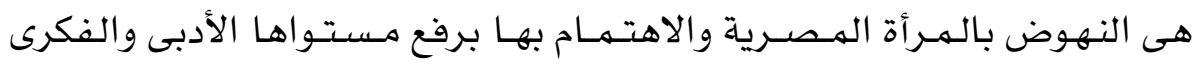

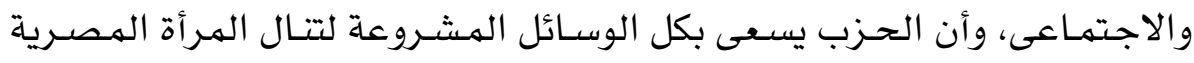

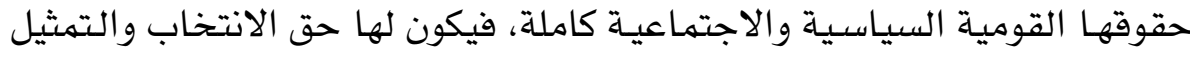
النيابى والتمتع بحقوقها كمواطنة مصرية. وللحزب برنامج تقصيلى آخر ضم العديد من المطالب التى دارت كلها حول

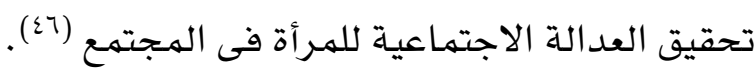
وقد ضم الحزب النسائى الوطنى فى عضويته خلال أشهر قليلة من تأسيسه

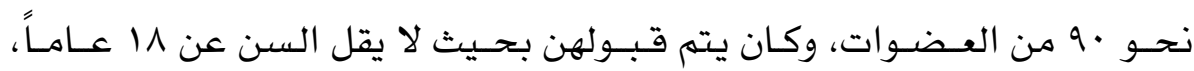

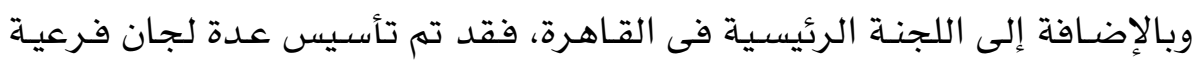

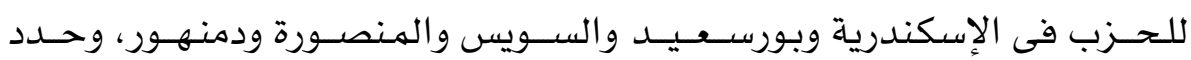


الاشتراك المالى للعضوية بـ •0 قرشـاً فى العام (IV). ويلاحظ هنا عدم تأسيس

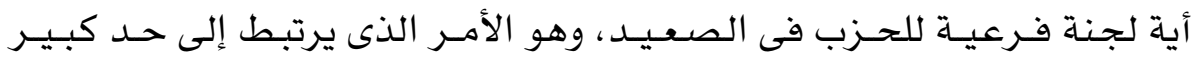

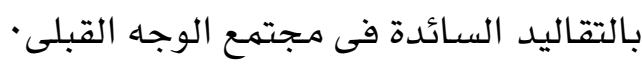

وأشـارت فـاطمـة نعـمت راشـد إلى أن مطلب حزيهـا الأول هو دخول مـجلس

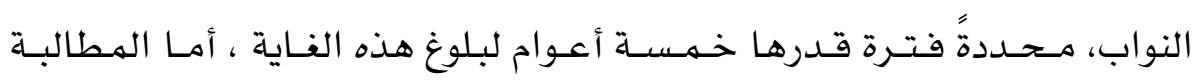
بانتخـاب المرأة فى مـلس الثـيوخ فقد رأت أنه مـن الأفضل تأجيل هذا الأهـر

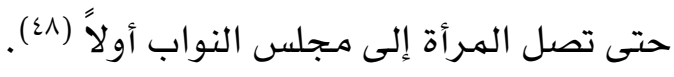

كهما حـرصت رئيسـة الحـزب على توضـيح عدم وجـود أية صلة بين حزبهـا

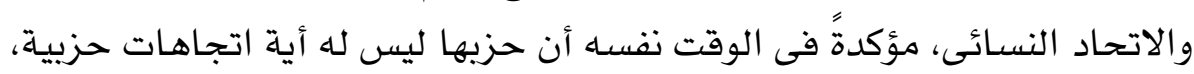

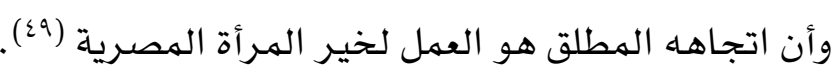
وفى يناير من عـام 19 إهـاء تأسـيس الحزب النسـائى الثالث، وذلك عندما قررت درية شفيق إحدى المناصرات لقضية الحقوق السياسية للمرأة، الدعوة

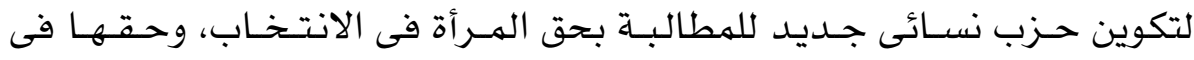
الترشيح للمجالس النيابية، وفى تولى الوظائف العامة الكبرى، وقد تبرعت درية لئه

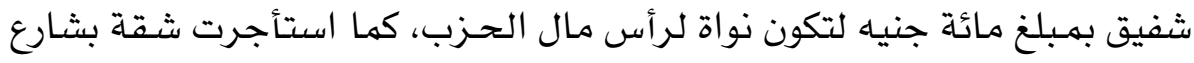

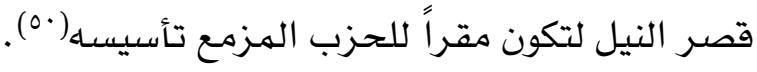
وفى TV أبريـل تم الإعـلان رسـهـيـاً عن تأسـيس اتحـاد بنت النيل للهطالبـة

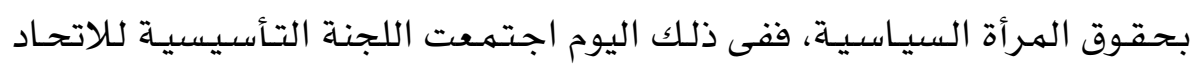

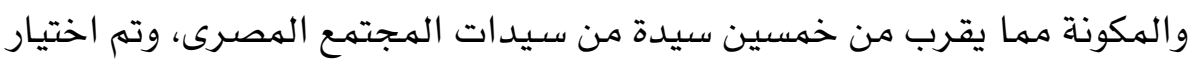

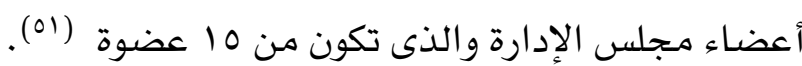

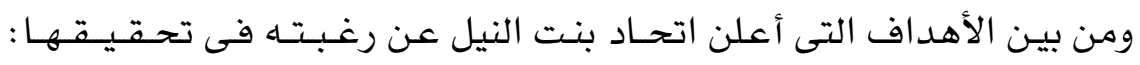

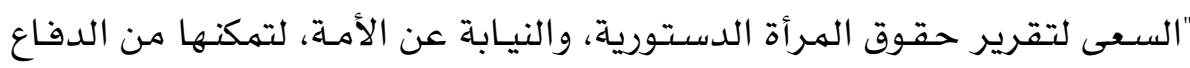
عن التشريع الذى يكفل هذه الحقوق" (Or). وبعد قيام ثورة بr يوليه ، صدر فى 9 سبتمبر r190r قانون تتظيم الأحزاب ، 
وقضى القـانون بأن من يرغب فى تكوين حزب سـيـاسى فـعليـه أن يحـيط بذلك

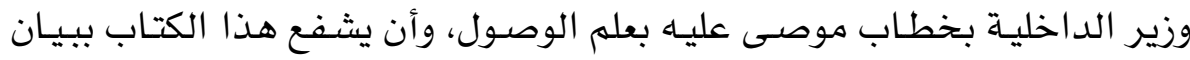
عن نظام الحزب في خلال شهرين من تاريخ إخطاره (or). وشهـد شـهر أكتوبر $190 r$ تقديم الأحزاب لإخطاراتها وهيئاتها التأسيسيـة

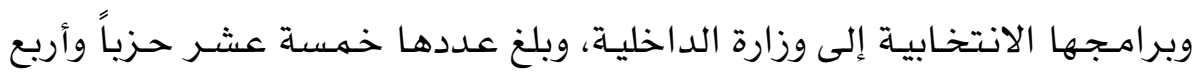

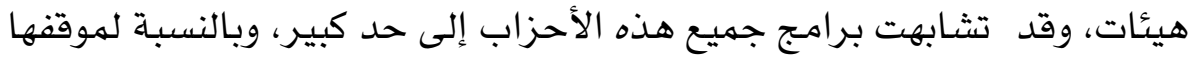

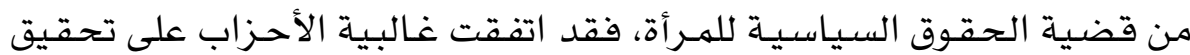

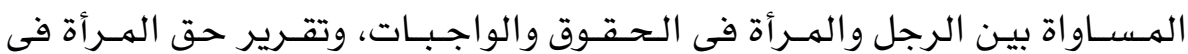

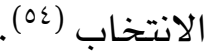

وقـد حـرصـت الأحـزاب النسـائيـة على تقديهم إخطاراتهـا تمسشيـاً مع قـانون

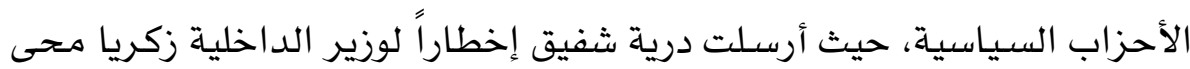
الدين جاء فيه " . . فتتفيذاً لقانون تتظيم الأحزاب أتشرف بـأن أتقدم بالإخطار

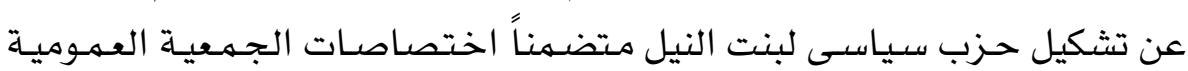

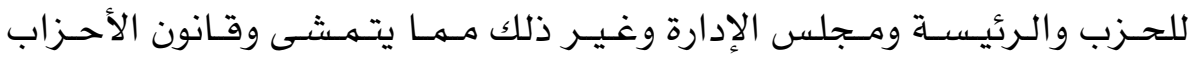

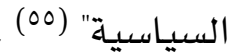

وتضـهن برنامج حزب بنت النيل فى سـياستـا الداخليـة فيهـا يتعلق بأوضـاع

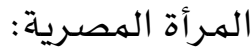
- تعديل قانون الانتخاب بما يسهـح للمرأة بهزاولة حق الانتخاب والترشيح. - المساواة الهطلقة بين الرجل والمرأة فى الحقوق والالتزامات (07) . وقد شهـد الحزب النسـائى الوطنى انشقاقاً فى صفوفه عام 190 1، حيث

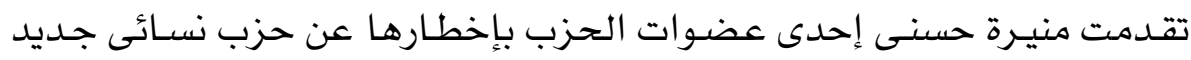

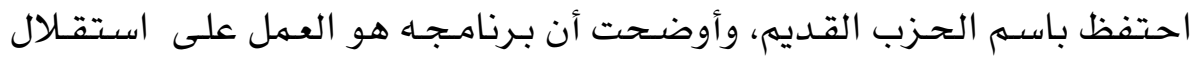

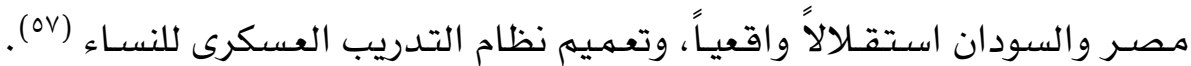

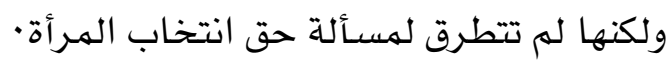


وحاولت فاطهـة نعمت راشـد رئيسـة الحزب النسـائى الوطنى مـعالجـة هذا

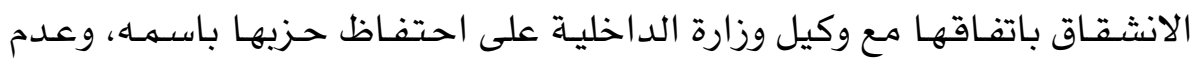

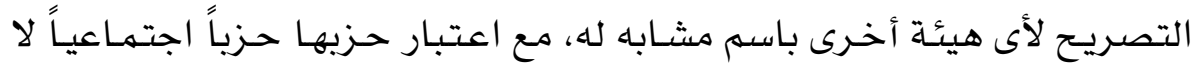

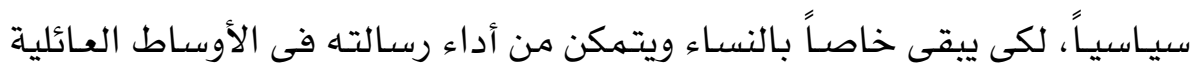
وبين الهوظفات والطالبات (01) .

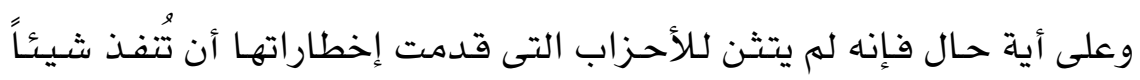

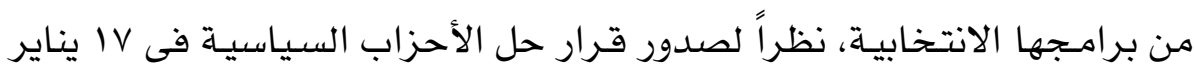

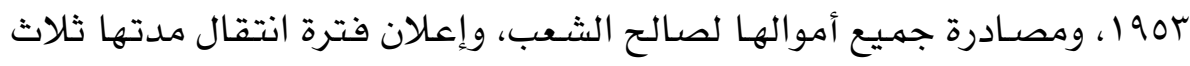

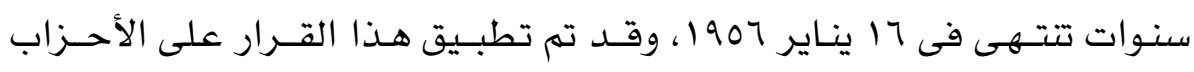

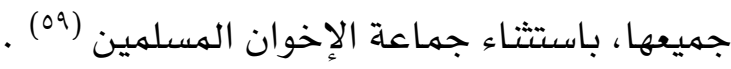

\section{• نظرة الهـتهـع لهبـدأ الهشاركة السياسية للهـرأة:}

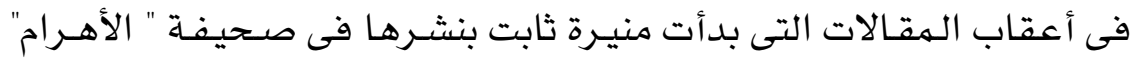
والتى طالبت فيها لجنة الدستور بمنـح المرأة حق التصويت والانتخـاب، يطالعنا

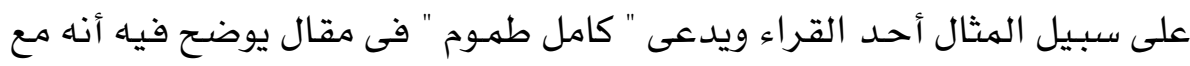

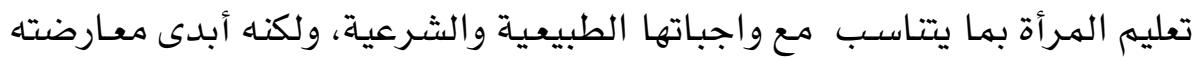

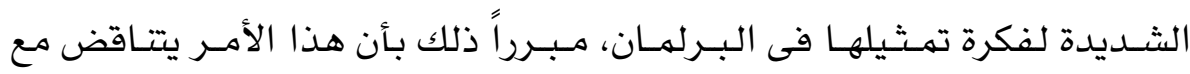
مهمتها الرئيسية فى رعاية الأسـرة (·ل).

ولم تقتصـر المعارضـة لمنح النسـاء حق الانتخـاب على الرجـال فقط، حيث

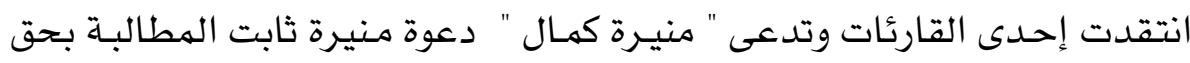

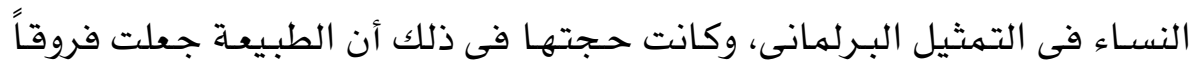

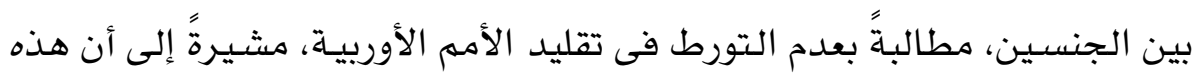

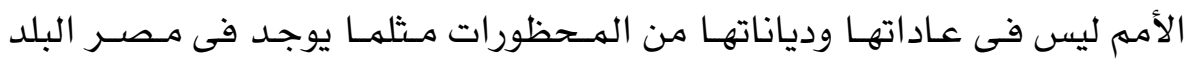

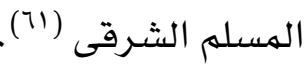
أهـا الرأى الهناصـر لحقوق الهـرأة السياسـية فقـد عرضهه " إسـهـاعيل فههى " 
الهـحـامى بالقـاهـرة، وذلك فى مقال له بعنوان " النسـاء فى البـرلمان الهصـرى" ،

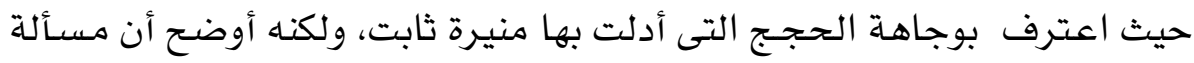

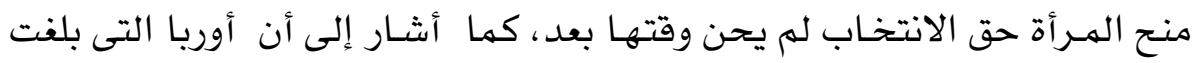

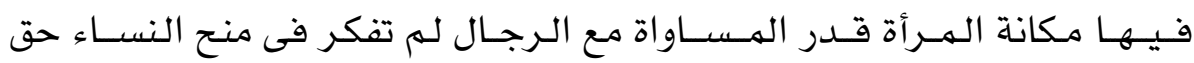

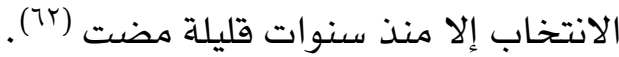

وجـاءت رؤية المفكر " ســلامـة موسى" بشـأن منـح الهـرأة حقوقها السـياسيـة،

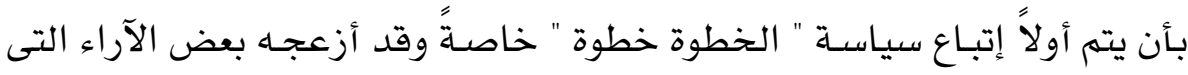

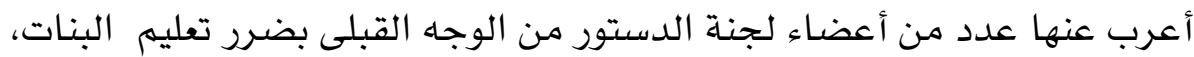

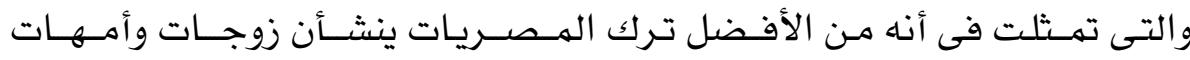
جاهـلات، ولذا طالب بمحاربة هذه الأفكار أولاً (rآ). وكان هناك ارتباط وثيق الصلة بين تضارب الأراء بشـأن منح المرأة الهصرية

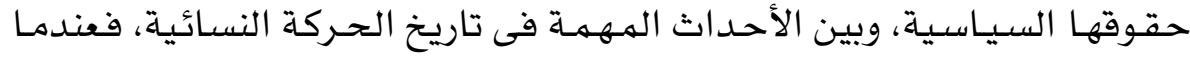

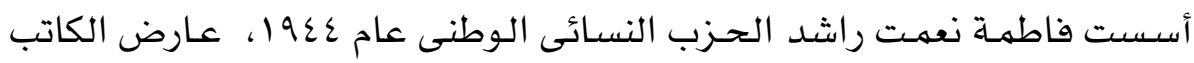

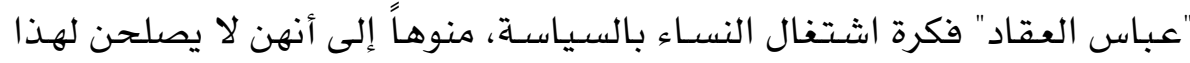

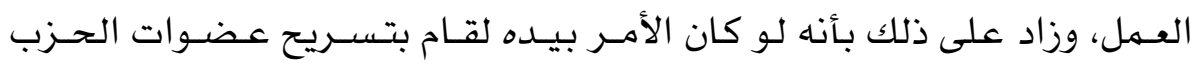

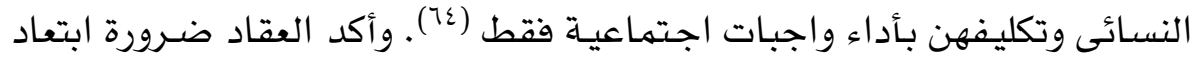

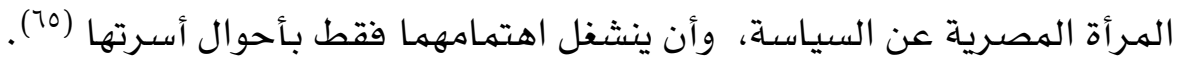

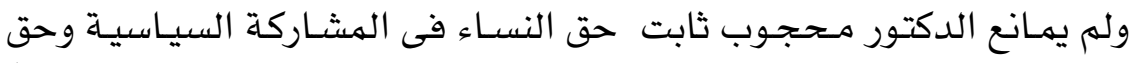

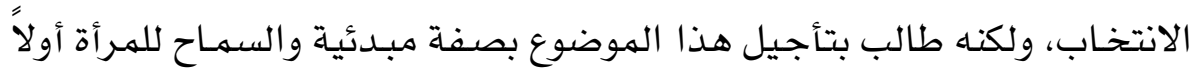
بعضوية المجالس المحلية وهجالس المديريات على سبيل التجرية (77). ويعُـــ الشـيخ أبو العيـون من أبرز علهـاء الأزهـر الذين أيدوا حـقـوق الهـرأة

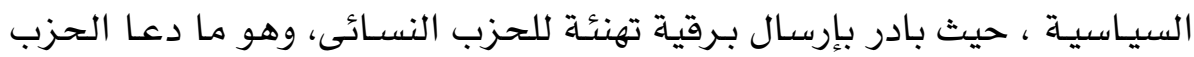

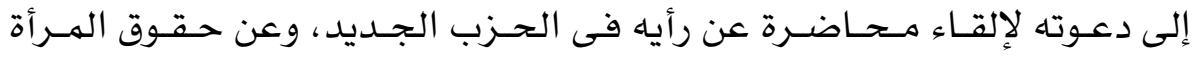

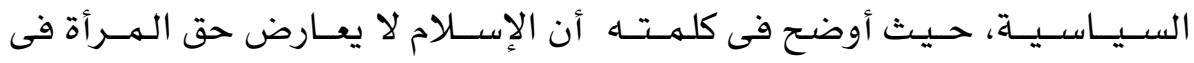


الانتخاب، ولكنه أشـار إلى أن الوقت له يحن بعد لمنحها هذا الحق، معللاً ذلك

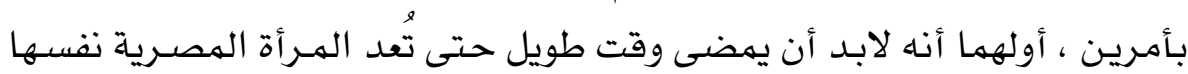

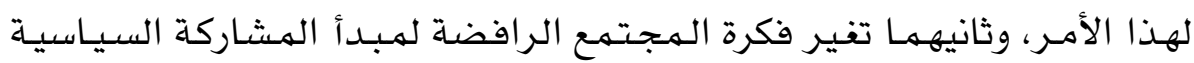
للمرأة وهو ما يتطلب وقتاً طويلاً (TV ).

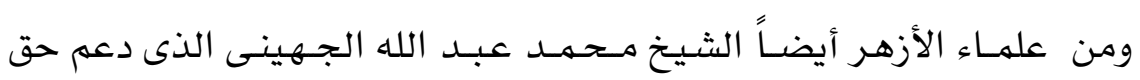

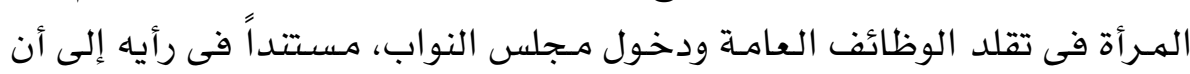

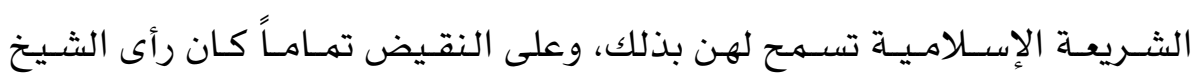
عبداللطيف دراز سكرتير عام الأزهر، حيث أعلن رفضه التام لمبدأ دخول الهرأة

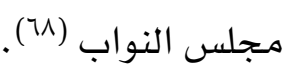
وقد انتهز محرر مجلة "مصر الفتاة " زيـارة عدد كبير من طلبة معهد أسيوط أسئ

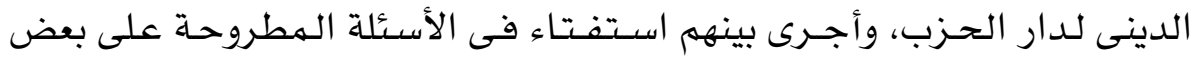

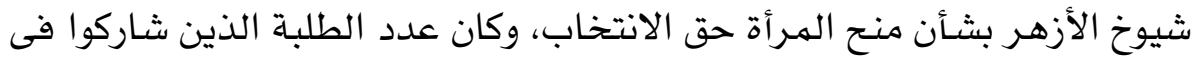

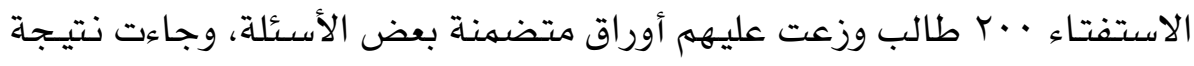

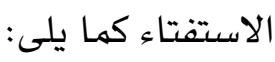

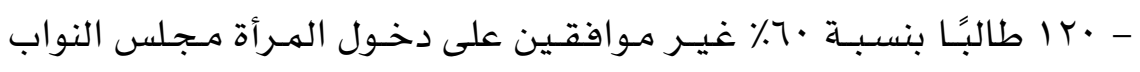
واشتر اكها فى الانتخابات(79).

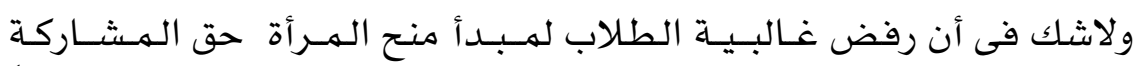

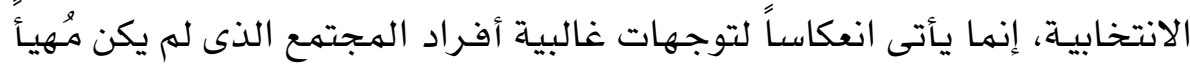

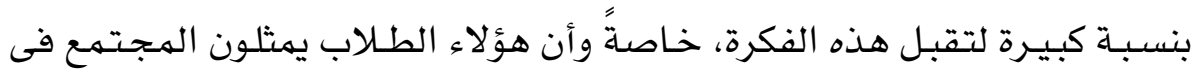

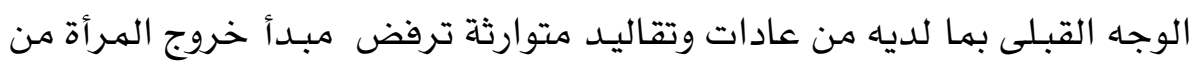
منزلها .

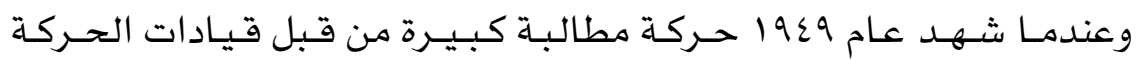

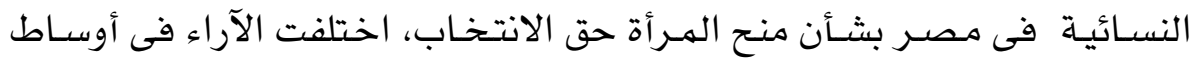

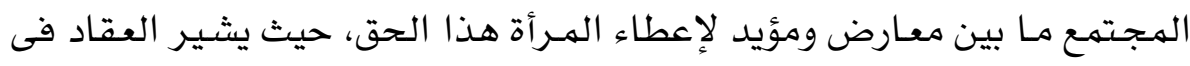

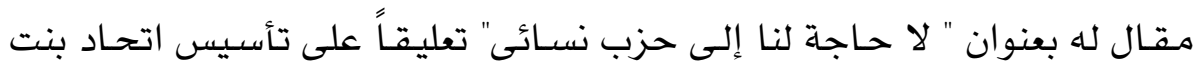


النيل، إلى أن الهــرأة لها رسـالة واحـدة فى الهـجــمـع وهى رعـاية الأسـرة وإعـداد

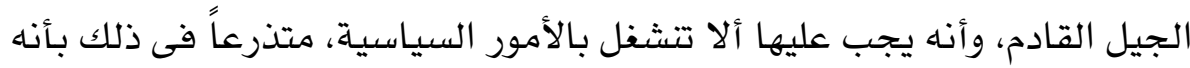

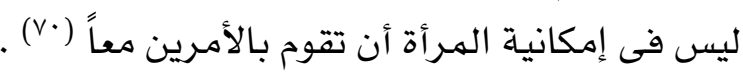

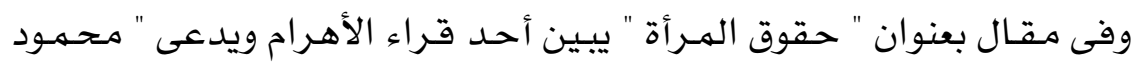

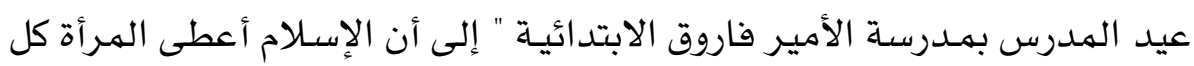

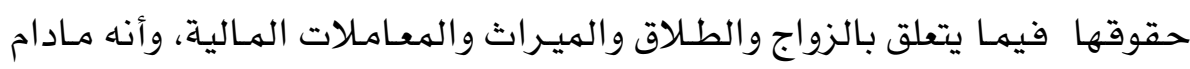

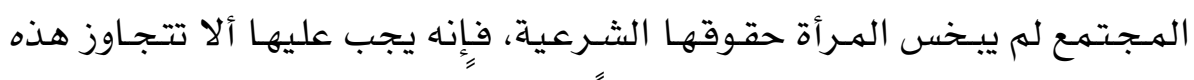

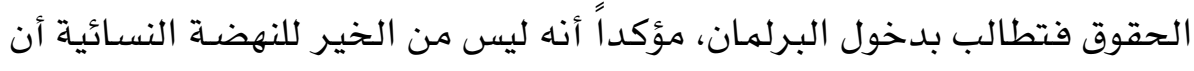

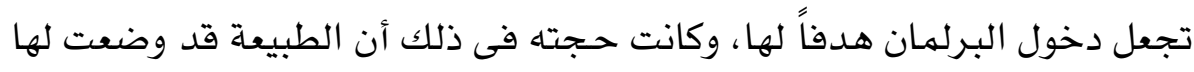

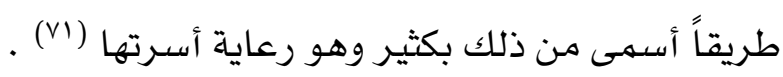

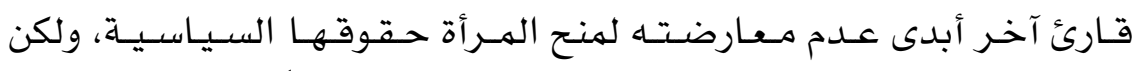

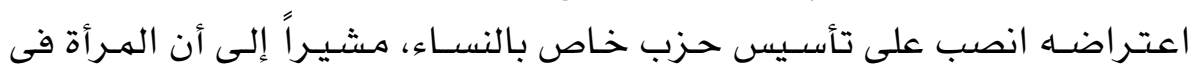

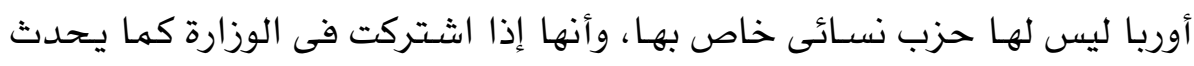

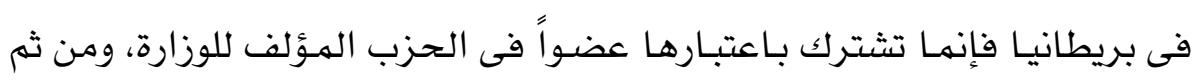

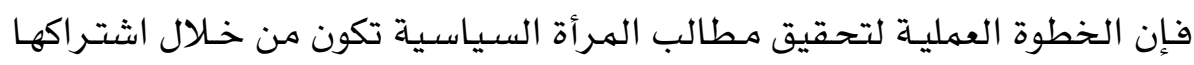
فى الأحــزاب السـيـاســـــة الهـوجـودة، وبـالتـالى عن طريق هذه الأحسزاب تككون

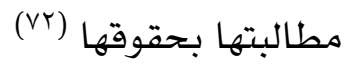
على الجـانب الآخـر كانت هناك أصـوات عديدة نادت بحق المـرأة فى دخول

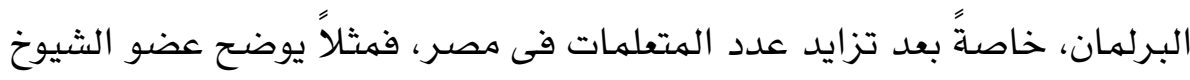

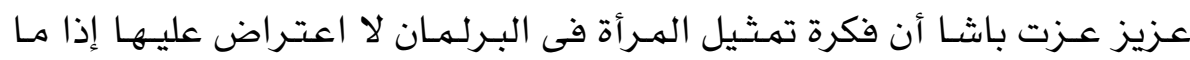

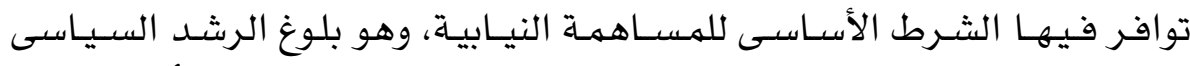

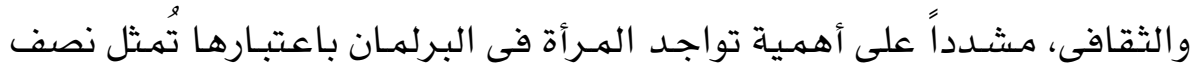

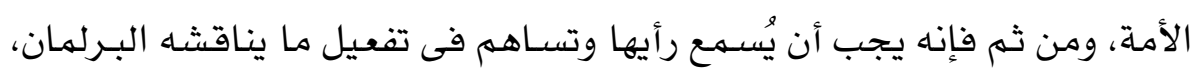

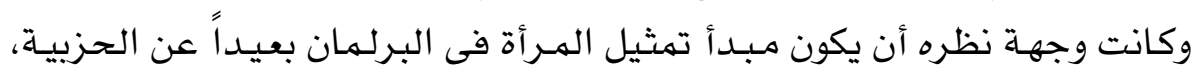

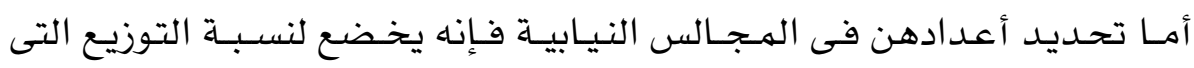


تقررها المصلحة العامة (Vr).

وفى هذا السيـاق أيضاً تُشير راوية عبد الفتاح(*) التى تتاولت عدة مقالات التهات

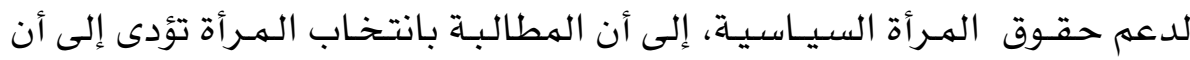

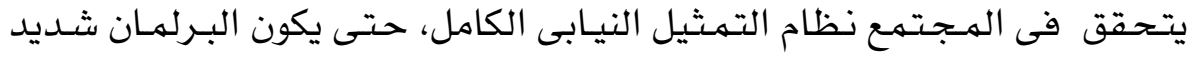

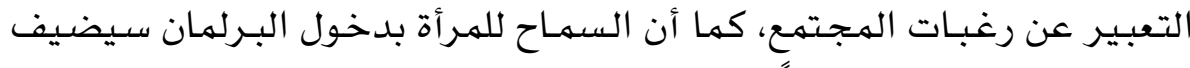

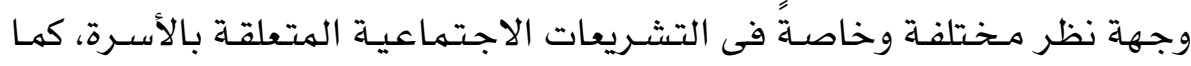

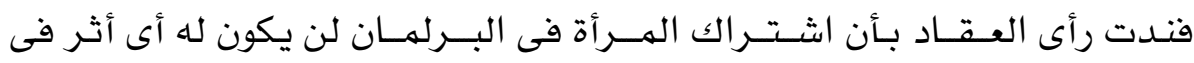

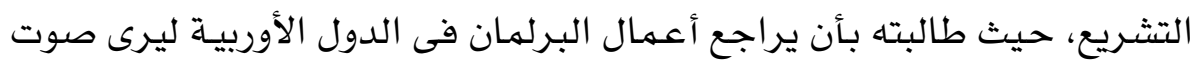

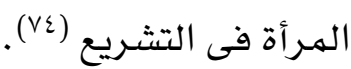

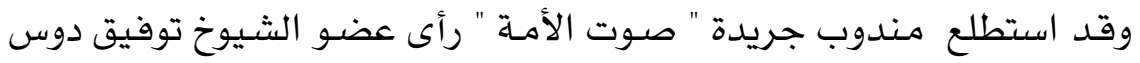

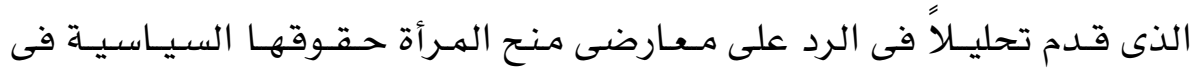
نقطتين: أولاً: أنه إذا كانت الشريعة الإسـلاميـة جدلاً لا تبيح للمرأة حق الانتخاب، فلن

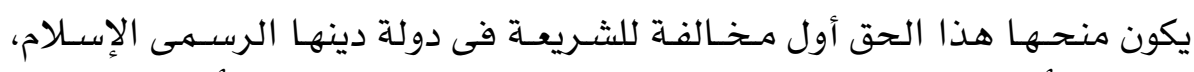

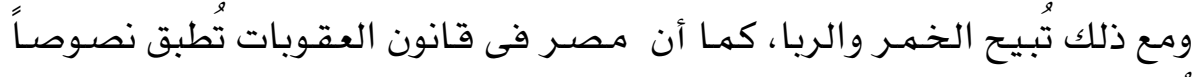

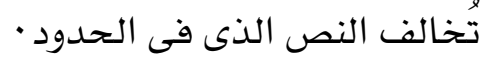

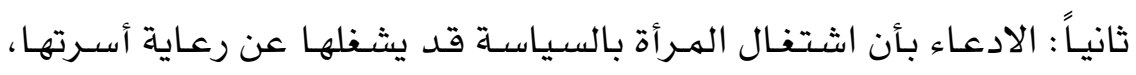

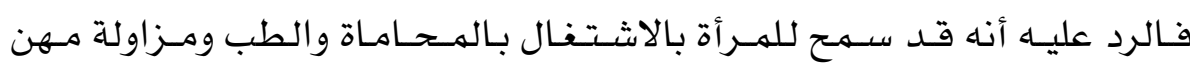
عديدة) في (vo).

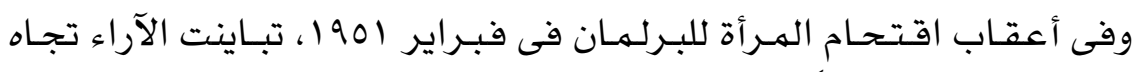

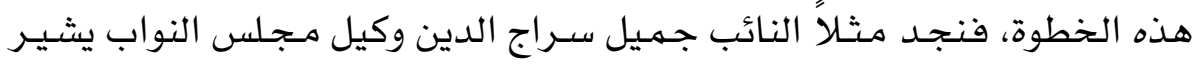

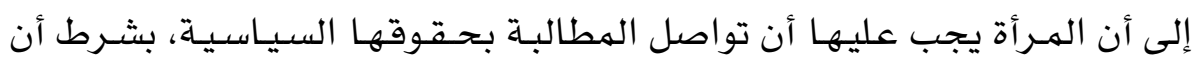

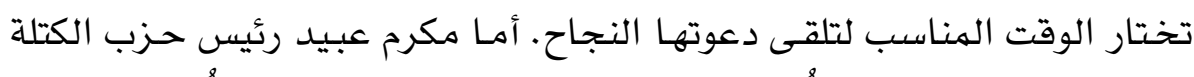

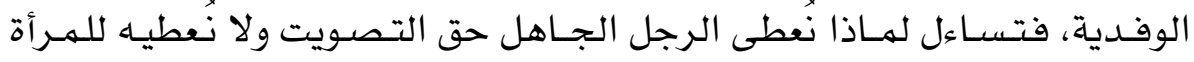




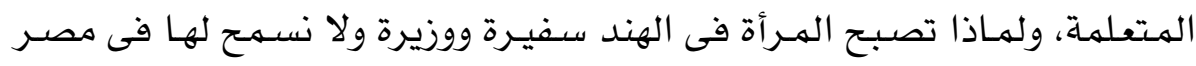
بهذا الحقى وأيد ما أقدمت عليه الهيئات النسائية لتفعيل مطالبها بصورة التهائ عملية.

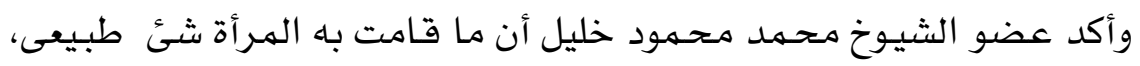

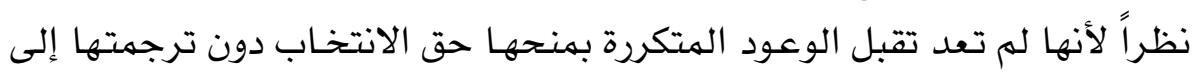

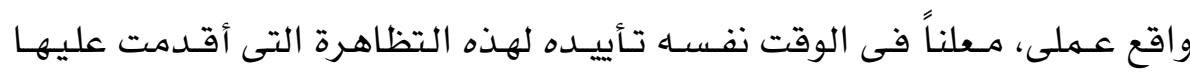

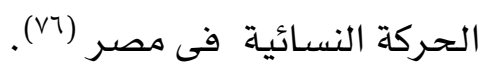

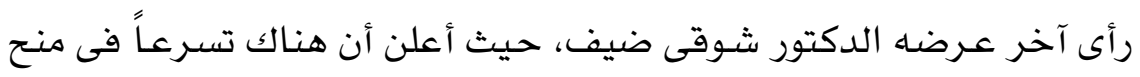

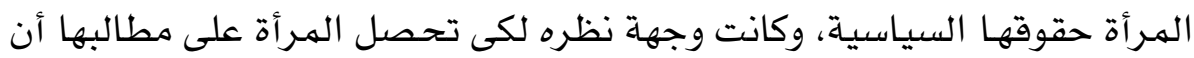

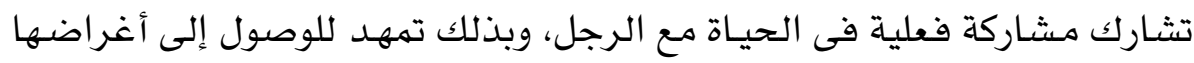

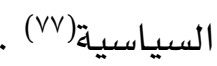

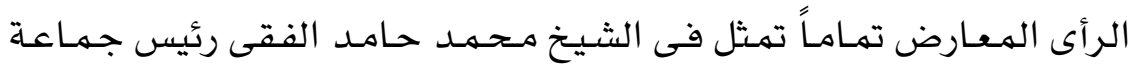

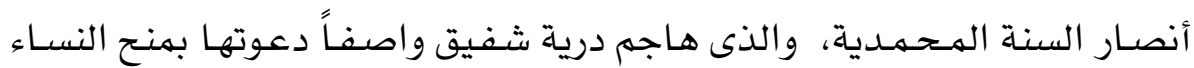

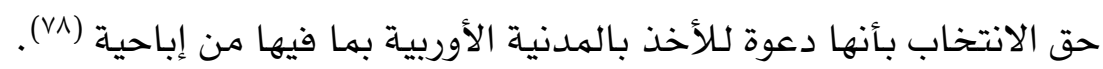

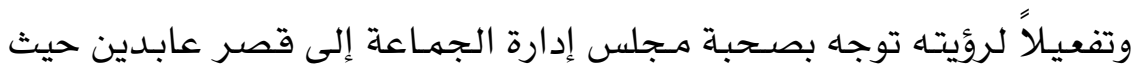

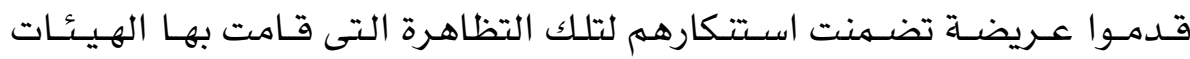

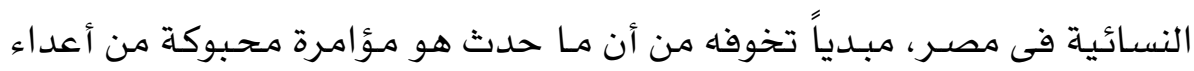

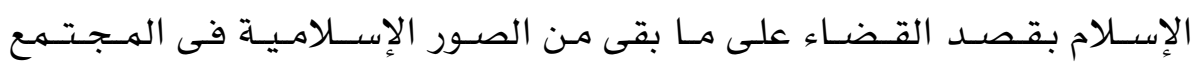

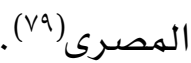

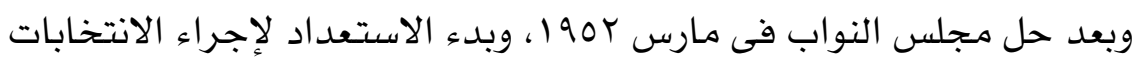

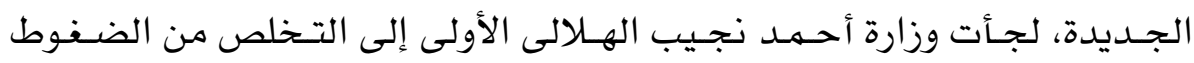

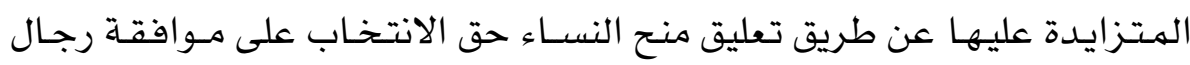

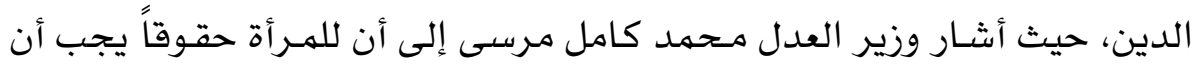

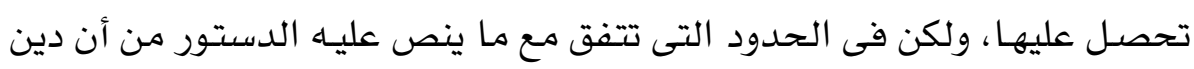


الدولة هـو الإســلام، ولذا أشــار إلى أنه يـجب مــــرفــة رأى الأزهــر في هـــا

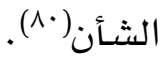

ومن المعروف أن مفتى الديار المصرية حسنين مخلوف كان قد أصدر فتوى

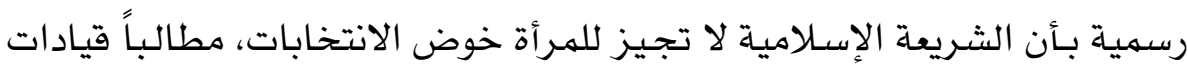

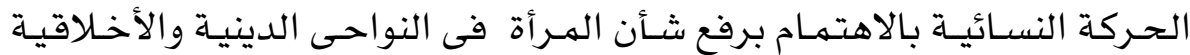

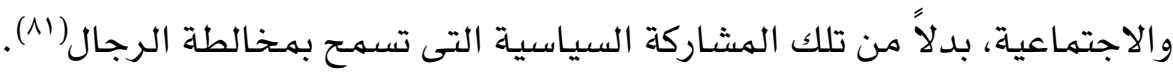
وقد دعم شيخ الأزهر عبد الهجيد سليم الرأى الذى أبداه الهفتى، حيث أكد أن المـرأة لا يجـوز لها أن تتتخب أو تشترك في الانتخـابات البـرلهـانية، إضـافة

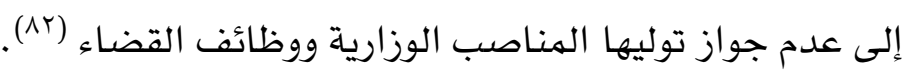
كما عقد الشيخ أحمد كامل الخضرى شيخ الهعهد الدينى بدمياط، اجتماعاً

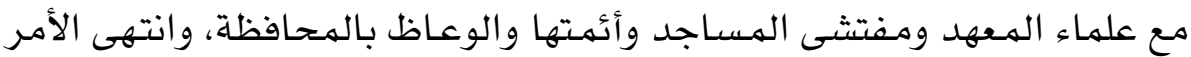

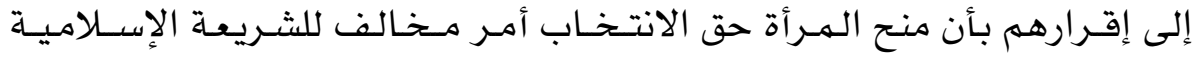

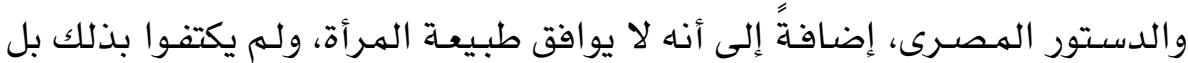

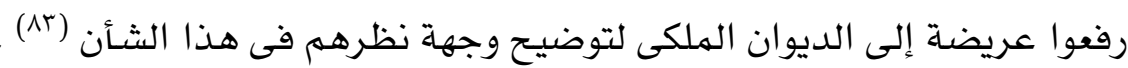
ويمكن القـول بـأن أكثـريـة الآراء التى كـانت تعـارض منـح المـرأة حـقــوقهــا

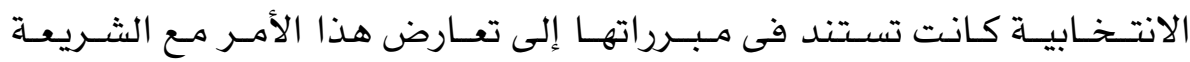
الإسـلامية، وقد تبنى هذا الرأى غالبية علماء الدين، وهو مـا بدا واضحاً في فئ آراء

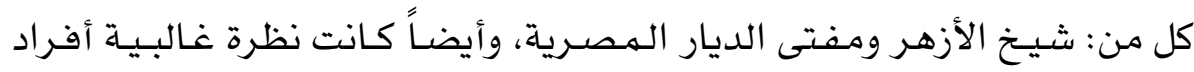

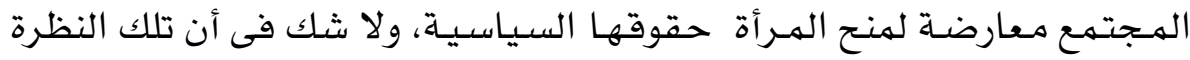

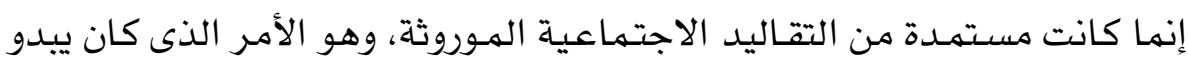
بصورة فعالة فى الوجاه القبلى بصفة خاصة . أيضـاً دارت نظرة الهـــهـع لهســألة منح الهـرأة حق الانتخـاب فى مـحورين

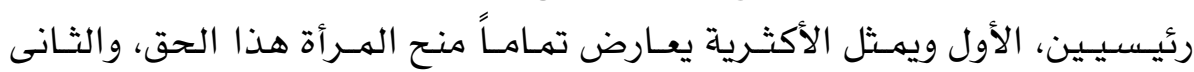

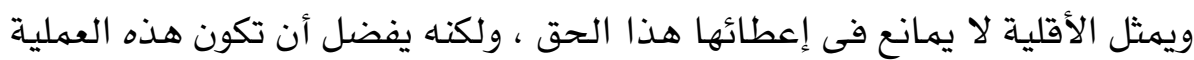


تدريجيـة عن طريق إشـراكها أولاً فى المـجـالس المـحليـة ومهــالس المـديريات،

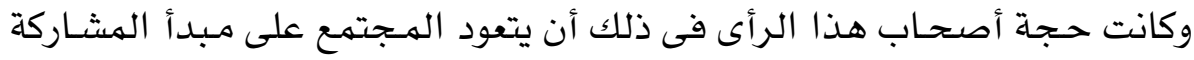

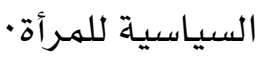

• جهود القيادات النسائية فى المطالبة بمنح المرأة حق الانتخاب:

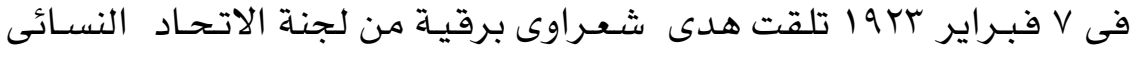

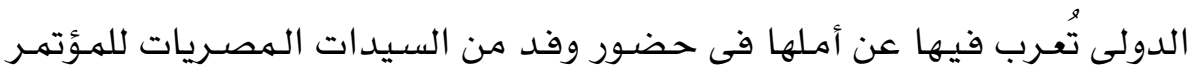

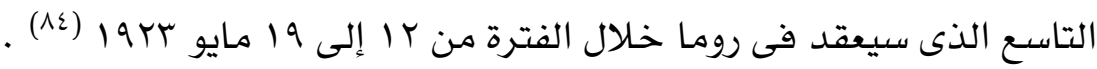
وعلى أثر ذلك وجـهت هدى شـــراوى الـدعـوة لعـضــوات الاتحـــاد النســائى

لمناقشة هذا الموضوع، وتمت الموافقة على قبول الدعوة، (10). وكانت النظرية التى عرضها الوفـد المصـرى على جانب كبيـر من الاعتدال،

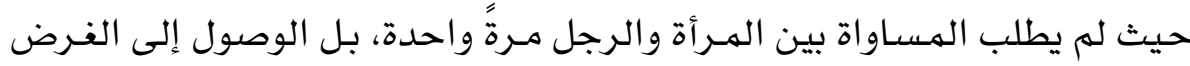

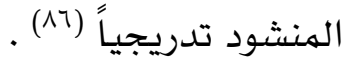

ومع ذلك فإن الاتحـاد النسائى له يتخل مطلقاً عن فكرة الهشاركة السياسية

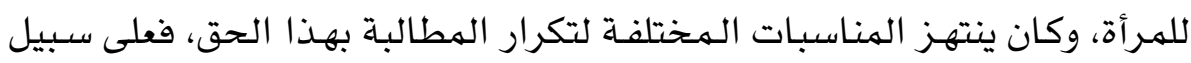
المثال فى المؤتمـر النسائى الذى عقـد بدار الاتحاد النسائى في ديسمبر من عام

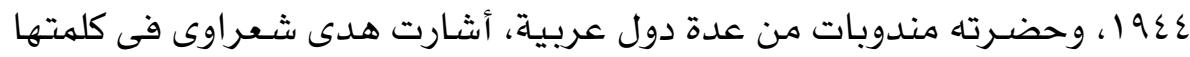

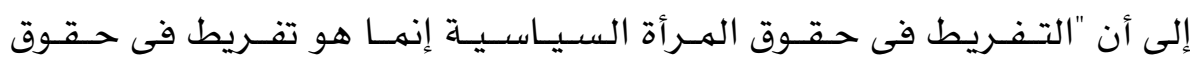

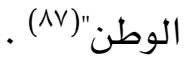

وفى عام 999 أرسلت بثينة شعراوى التى تولت رئاسـة الاتحاد النسـائى بعد

وفاة هدى شعراوى مذكرة إلى رئيس مجلس الشيوخ محمد حسين هيكل، أشـارت

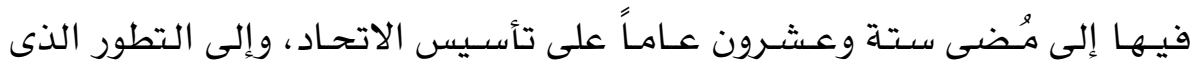

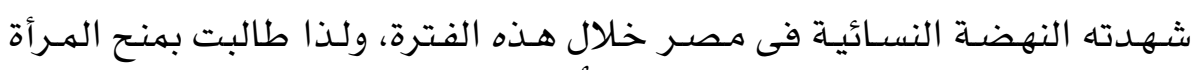

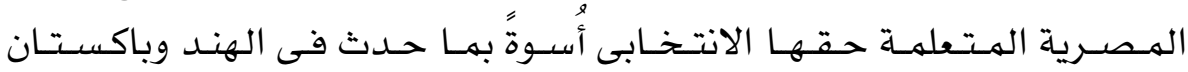
وأندونيسيا (^^) 
وتأتى منيـرة ثابت كأول من طالبت بمنح المرأة المصرية حق الانتخاب، وقد

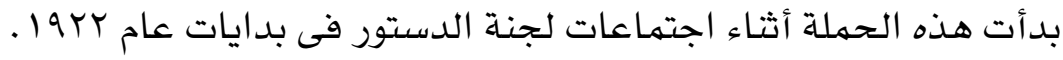

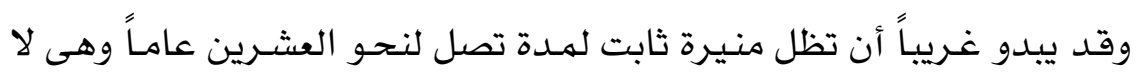

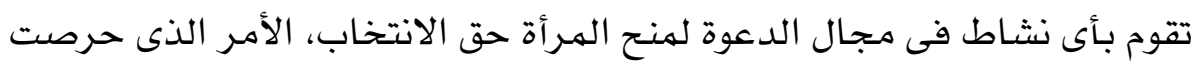

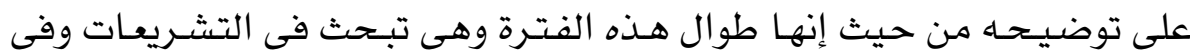
تاريخ الحركات النسائية العالمية والتطورات القانونية المحلية.

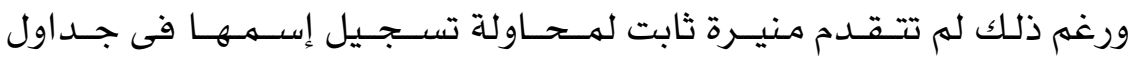

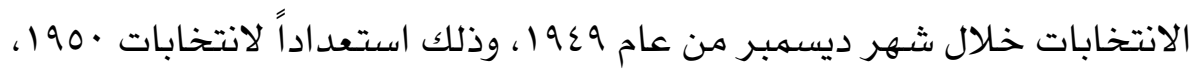

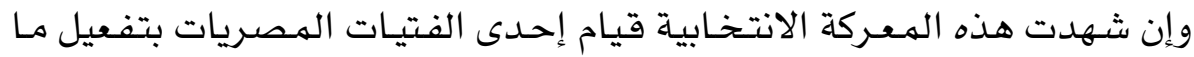

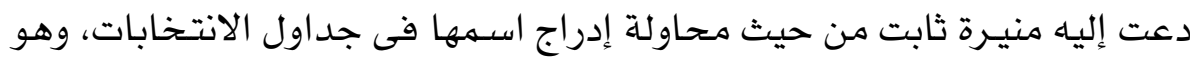
ما سنعرض لله في موضعه. وبعد إعـادة إصـدار مـجلة الأمل فى عـام 190 1، بدأت منيـرة ثابت فى كتابة

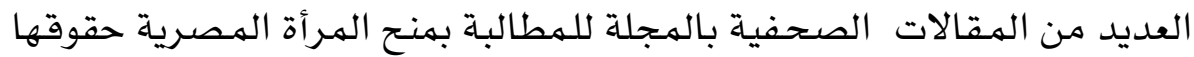

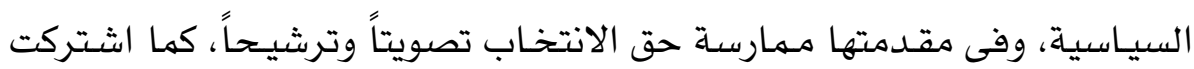

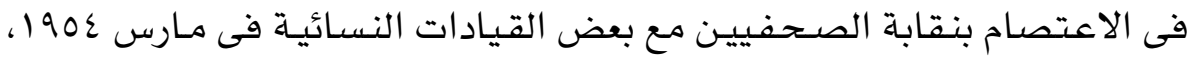

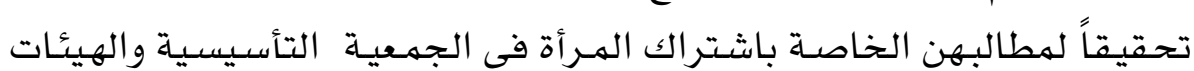
التشريعية.

وفى منتـصف مـايو 1900 طالبت منيـرة ثابت حكومـة الثورة بضــرورة وضع

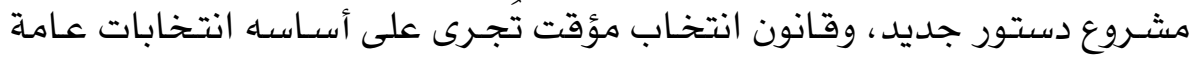

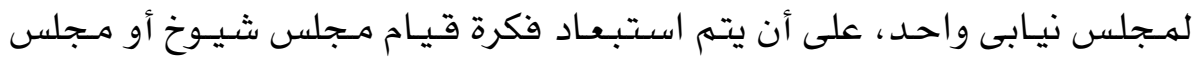

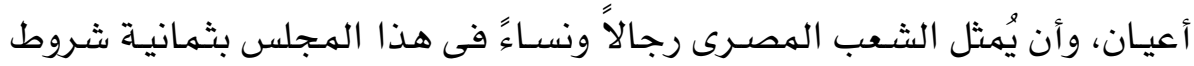
تم تخصيص شرطين منهما للمرأة وهما :

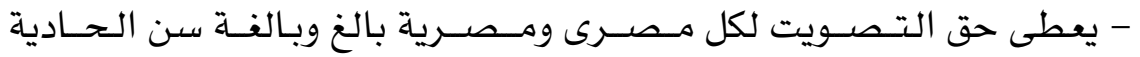
والعشرين بشرط إجادة القراءة والكتابة إجادة تامة • 
- يعطى حق التـرشيح لكل مـصـرية بالغـة من العمـر ب معامـاً، ويشترط أن تكون فى مستوى علمى جامعى أو ما يعادله (19).

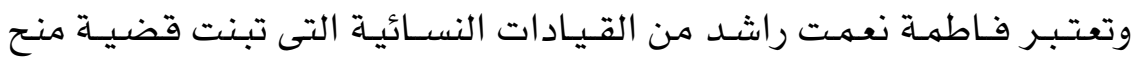

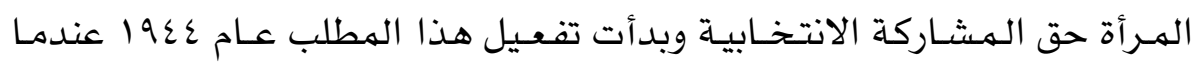
أسست الحزب النسائى الوطنى، حيث تتاول قانون الحزب في مادته الثانية مبدأ

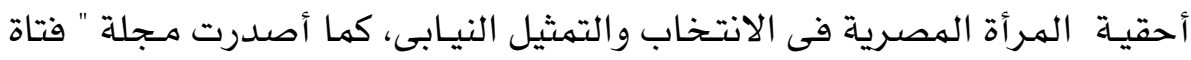

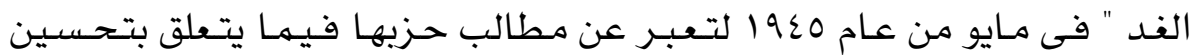
أوضـاع الهـرأة الهصريـة ، لكن الهجلة ما لبتثت أن توقفت عن الإصـدار في أواخر

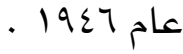

وفى عام 19 أرسـلت فاطمـة نعمت راشد عريضدة باسـم حزبها إلى مـجلس الشيوخ، طالبت فيها بتعديل قانون الانتخاب، بحيث يعطى للمـرأة المصـرية حقها

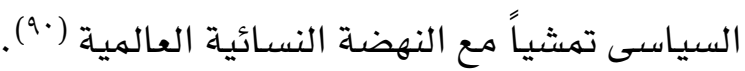

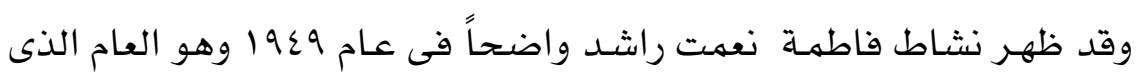

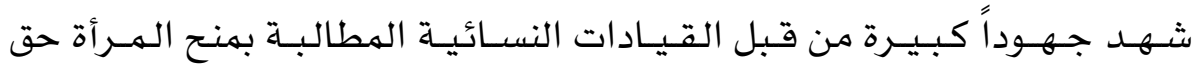
الانتخـاب، فقى أوائل أبريل من هـذا العام تم عقد اجتماع نسـائى برئاسـة فـاطمة

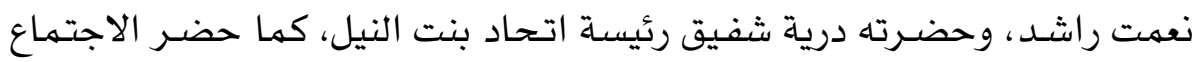

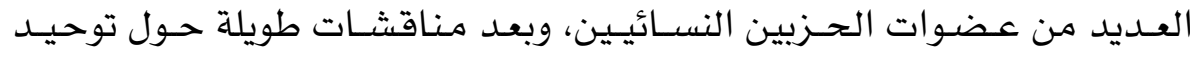
صفوف القائمات بالحركة النسائية الهصرية تم التوصل إلى القرارات التالية: - قيام إنتّلاف مؤقت بين كل من الحزب النسـائى الوطنى واتحـاد بنت النيل،

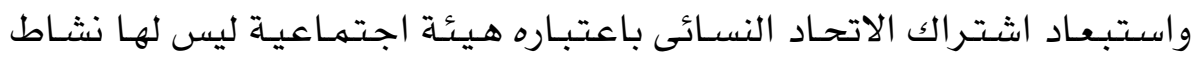

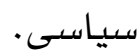
- توحيد وسـائل العمل وتتظيم صفوف القائمـات بالحركة النسـائية، وإعـداد بعض النشرات لتوزيعها على الأهـالى عن الحقوق السياسية للمرأة الهصرية. 
- الاسـتعـداد للمعـركـة الانتخـابيـة واسـتفـلالها فى الـدعاية لقضيـة الهـرأة

- قبول بعض الشخصيات المصـرية من الرجال ممـن أيدوا الحركة النسـائية

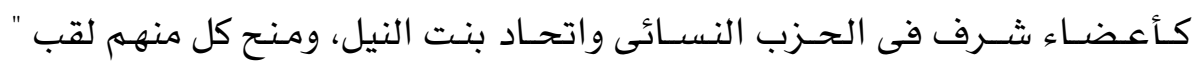
نصيـر المرأة " ومساعدتهم فى المعركة الانتخابية، وقد رشتح لهذه العضوية كلاً من: محمد خطاب، وزهير صبرى، وشوكت التونى.

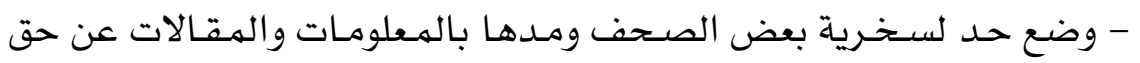
المرأة الهصرية فى أن تتال حقوقها السياسية كاملة (19).

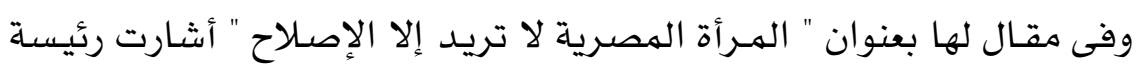

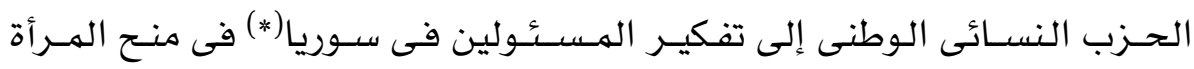

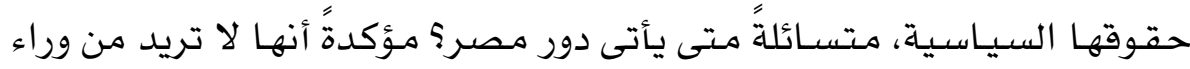

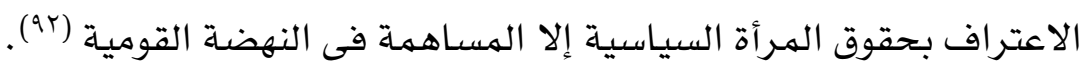

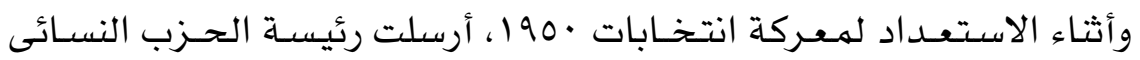

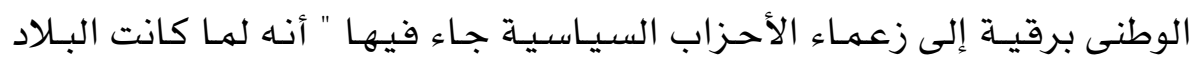

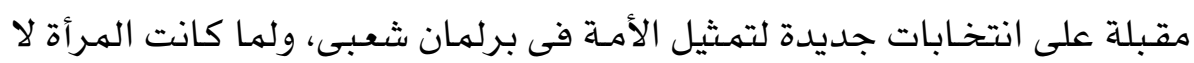

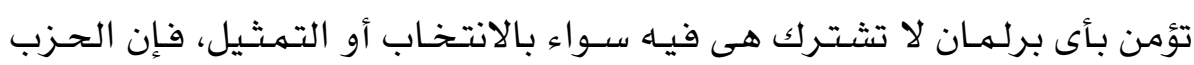

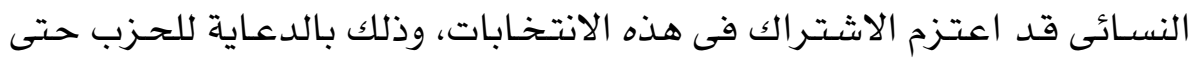

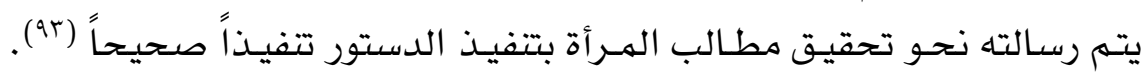

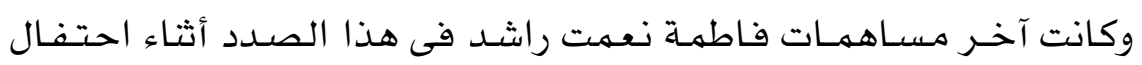

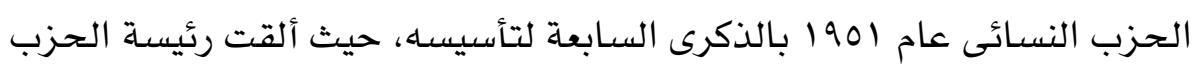

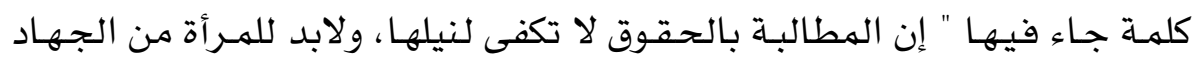

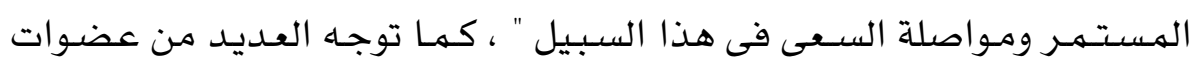

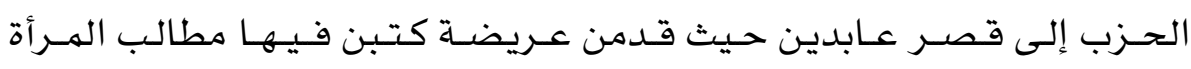

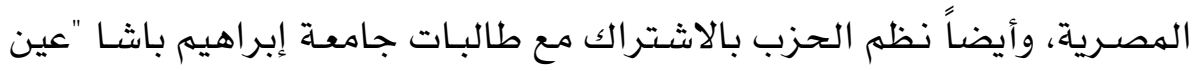

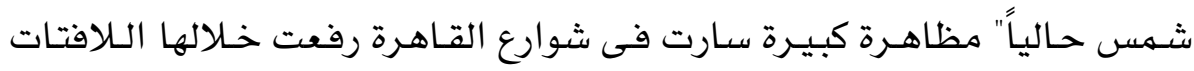


المطالبة بالحقوق السياسية للمرأة (ع9).

ومثلث درية شفيق إحدى القيادات النسائية التى كان لها دور فعال فى دعم

المطالبـة بحقـوق الهـرأة السيـاسـيـة، وقـد بدأت نشاطها في هذا الهـــال عندمـا أصـدرت مـجلة " بنت النيل" عـام 19 19، وتم تفـعيل هذا النشـاط بصـورة أكبـر

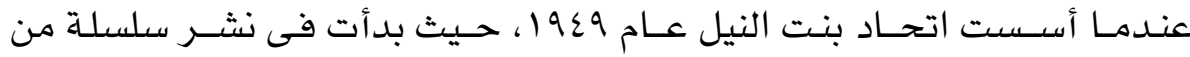

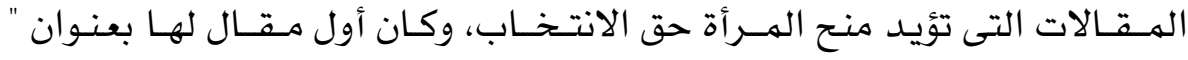

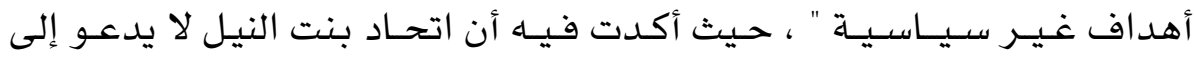

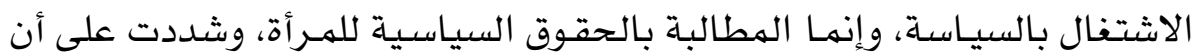
منح النسـاء حقوقهن الانتخابيـة لن يمنعهن عن واجبهن الأول فى البيت وحيـال

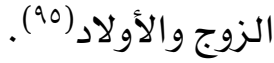

وعندما فاز الوفد بأغلبية مجلس النواب عام •190، كتبت درية شفيق مقالاً

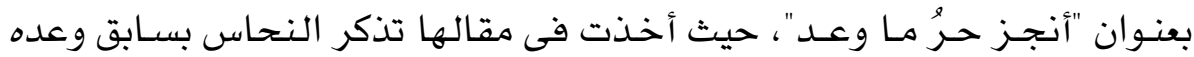

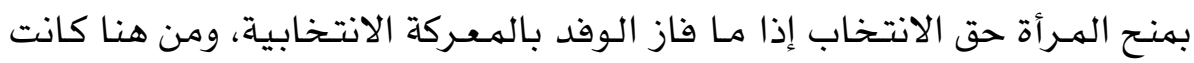

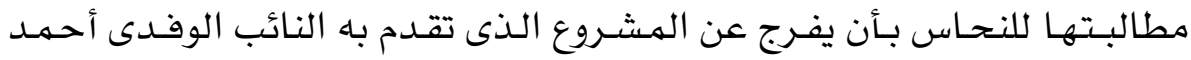

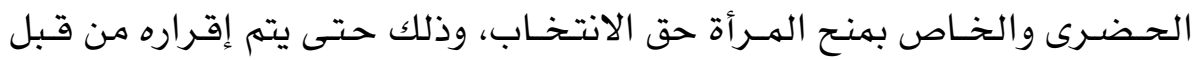
البرلمان (97) (97)

ويعتبـر يوم 19 فبراير 1901 من أبرز العـلاهـات فى نشاط الحركة النسائيـة

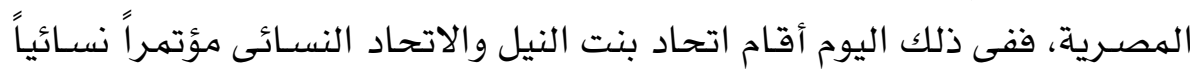
فى قاعـة ايوارت بالجـامعـة الأمـريكيـة حضره أكثر من ألف سيـدة وفتـاة يمثلن

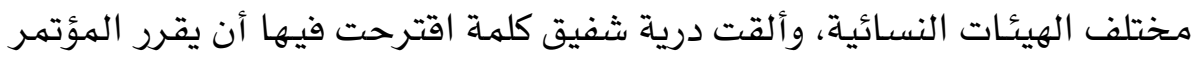
تعديل قانون الانتخاب بهـا يصون للهصـريات حقوقهن السياسيـة التى كفلها

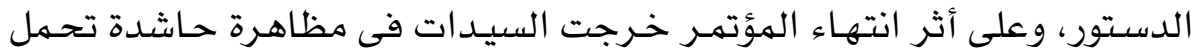

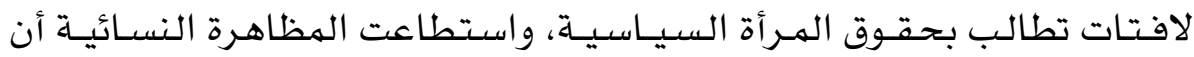

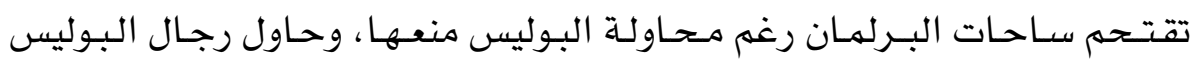


إخراج الهـظاهرات بالقوة فلم يتمكنوا بالرغم من إصـابة بعض السـيـات بعـدة

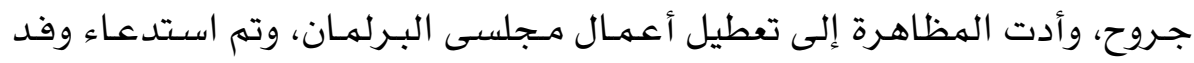

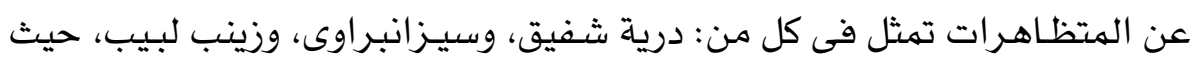

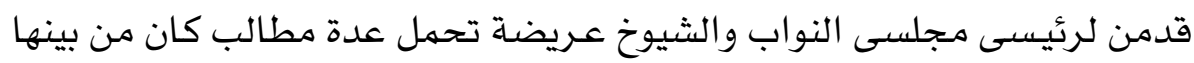

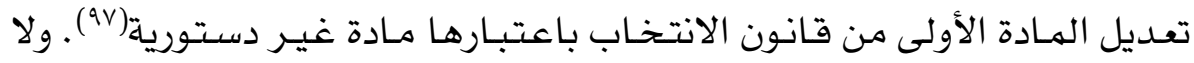

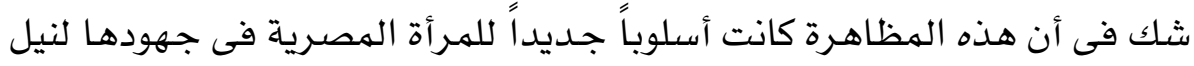

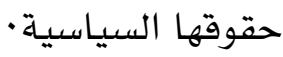
وكان لتلك الخطوة التى أقدمت عليها الهـرأة الهصرية صدى واسـع فى العالم الغـربى، حيث خـرجت عشـرات الصـحف بعناوين بارزة منها على سبيل المـثال "

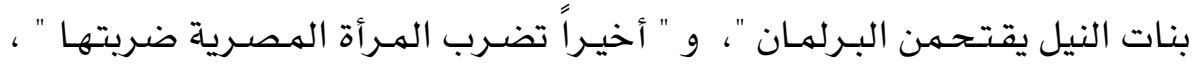

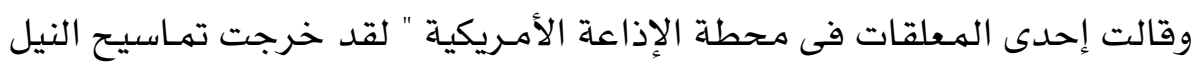
بعد احتجاب طويل، خرجت هذه المرة تدافع عن كيانها بـلا دموع" (91). وقد علقت مجلة " الايكونوميست " البريطانية على هذه التطورات فى حركة

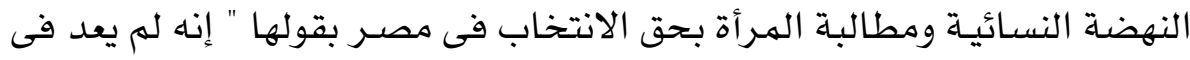

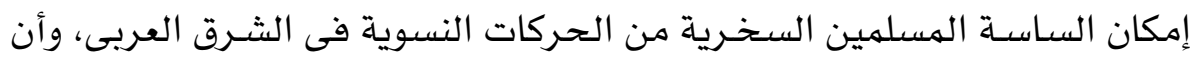

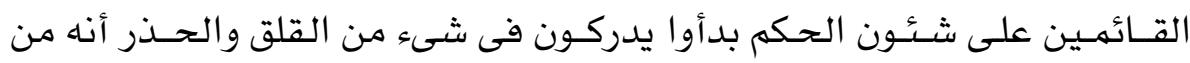

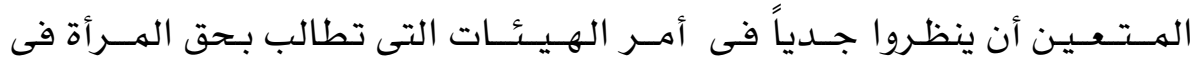
الانتخاب(99).

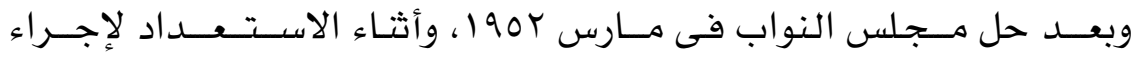

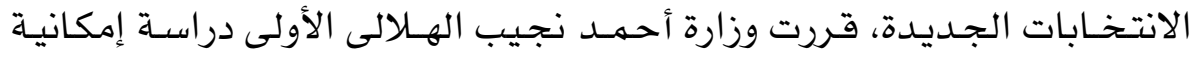
إجراء بعض التعديلات على قانون الانتخـاب، وهنا طالبت درية شفيق المسئولين

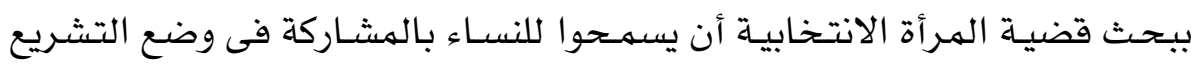

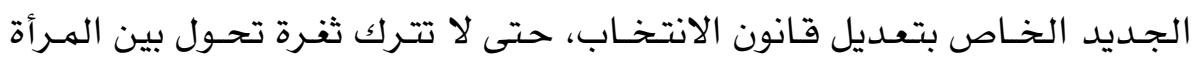
المصرية وبين استكمال حقها الانتخابى (.'). 
وفى مقـال لها بعنوان " التمثثيل الكامل للشعب " أشـارت درية شفيق إلى أن

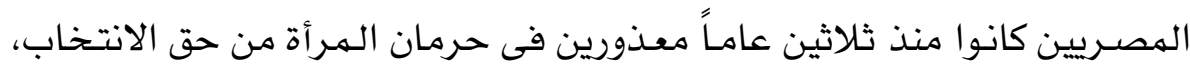

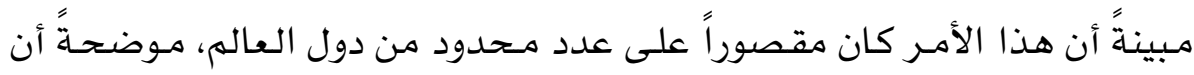

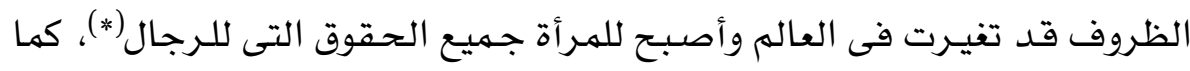

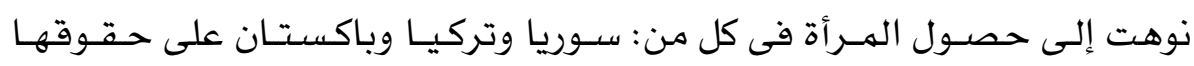

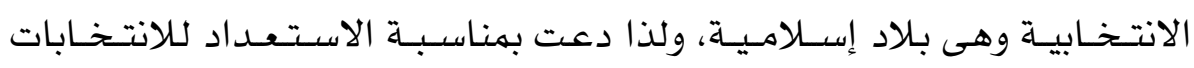

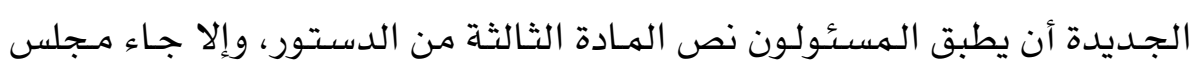

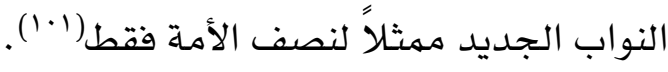

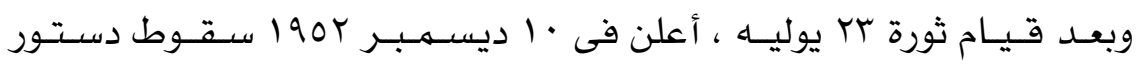

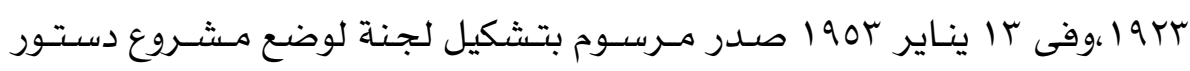

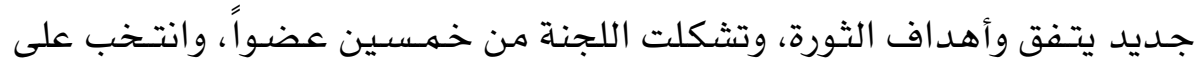

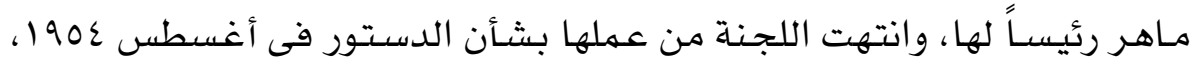
أى بعد مضى أكثر من عام ونصف على تكوينها (r.1).

وكان من ضهمن الموضوعات الهقترحة التى ستبحثها لجنة الدستور السهاح

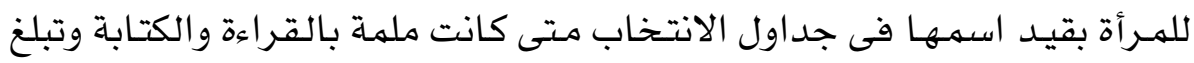

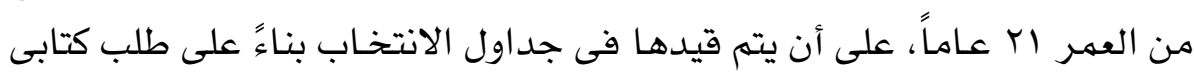

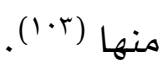

كما قرر مجلس قيادة الثورة بجلسة ه مارس ع ع 190 اتخاذ الإجراءات اللازمة

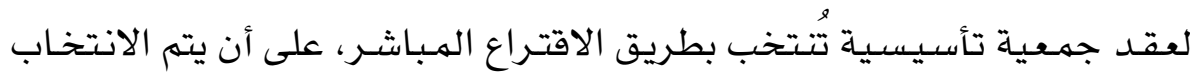
خلال شهر يوليه ع 190، ويكون للجمعية مهمتان: أولاً: مناقشة مشروع الدستور الجديد وإقراره·

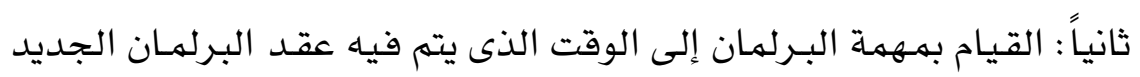

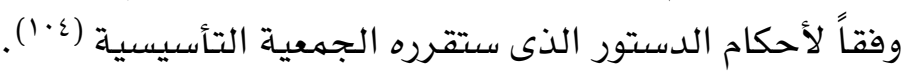
غيـر أن هذا القـرار جعل انتخـاب الجهـعيـة التأسيسيــة على أسـاس قـانون 
الانتخاب القديم، وهو القانون الذى يجعل التصويت والترشيح حكراً على الرجال فقط (1.0).

ولعل أبرز ما قامت به درية شفيق اعتراضاً على تجاهل الهرأة الهصرية فى

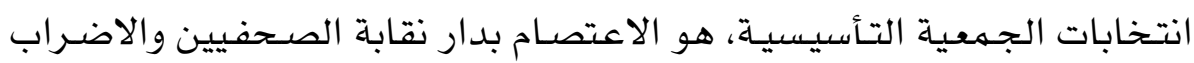

$$
\text { عن الطعام (1) - (1). }
$$

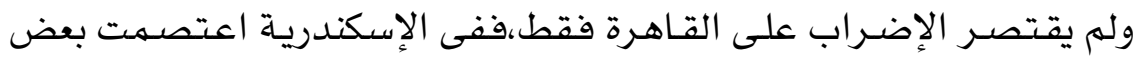

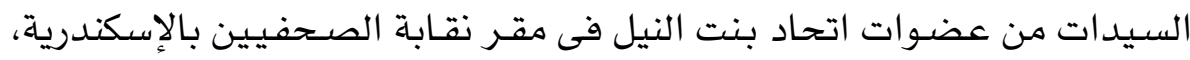

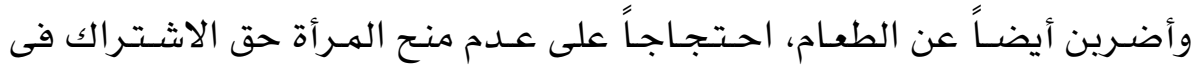

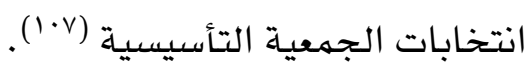
وقد استهمر الإضـراب ثمانية أيام كاملة، ولم يتم فضه إلا بعد وصول رسـالة من رئيس الجمهورية اللواء محمد نجيب جاء فيها " لقد تلقيت طلبكن وأحيل إلى

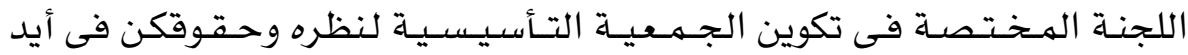

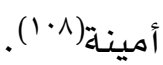

ولم يُقدر للمرأة المصرية المشاركة فى انتخابات الجمعية التأسيسية، نظراً

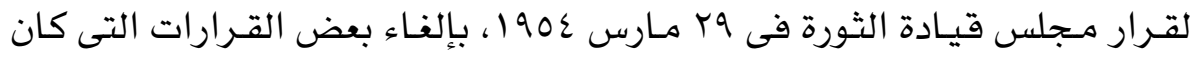
الهجلس قد أصدرها من قبل، ومن بينها قرار انتخاب الجمعية التأسيسية (9.1). وكانت آخر مطالبات المرأة فى هذا الصدد عندما أسست اعتدال حمودة(*)

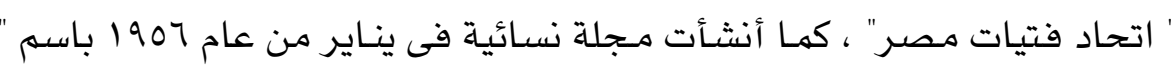

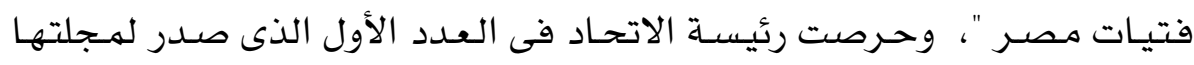
على توضيح أهداف الاتحاد، والتى دارت حول خمسـة مبـادئ كلها تتعلق بالمرأة،

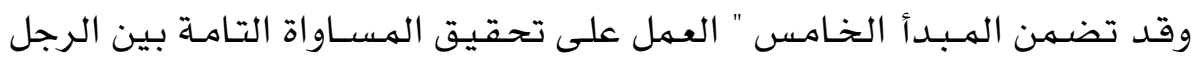

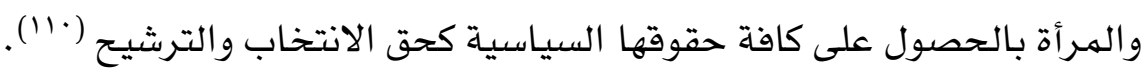


• مساهمة الهرأة فى الحركة الانتخابية قبيل ثورة يوليه ra01:

لم تقف جهـود الهـرأة المصـرية عند حد المطلالبـة بمنـحهـا حق الانتـخـاب،

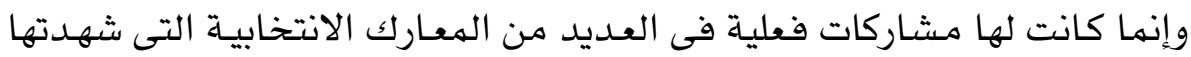

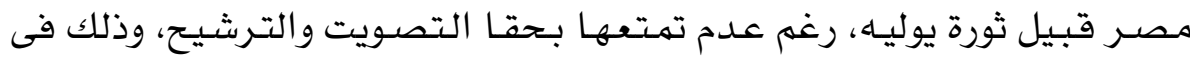

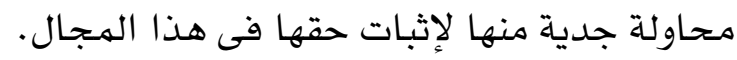
وكانت بداية المشاركة الفعلية للمـرأة فى الحـركة الانتخـابية أثناء انتخـابات

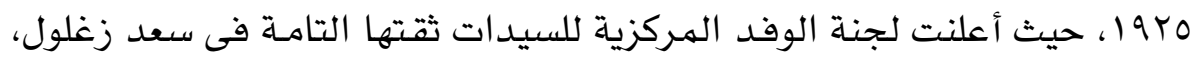

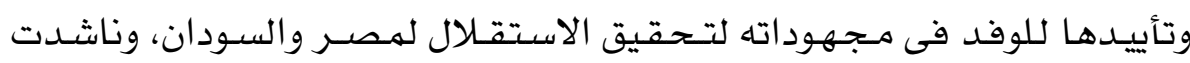
اللجنة المصريين أن يؤيدوا مرشحى الوفد في الانتخابات (1'1'). وشهـــت انتخـابات 19 مـولد لجنة نسـائية جديدة وهى اللجنة السـعـية

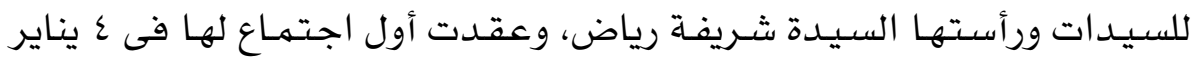

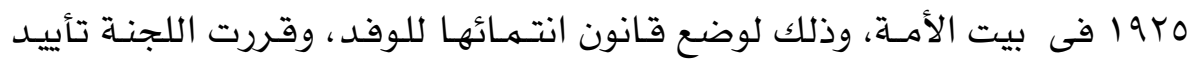

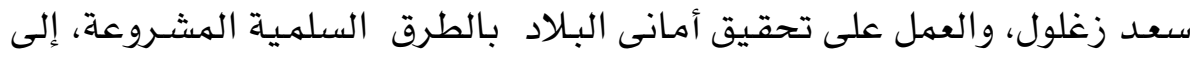
جانب العهل على إعـادة الحياة النيابية ومساندة مـرشحى الوفد فى المعركة الانتخابية (1'r) (1I) ويشير مـراسل صحيفـة " المانشستر جـارديان" فى برقيـة له إلى أن الحركة النسائية فى مصر قد اكتسبت " صفحـة واضحة في الحملـة الانتخابيـة " (rII) .

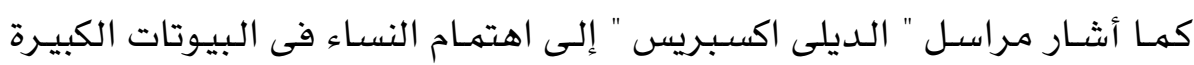

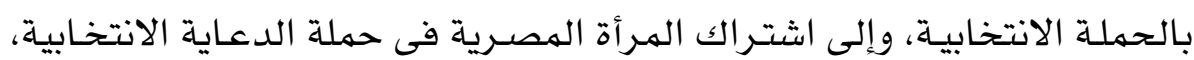

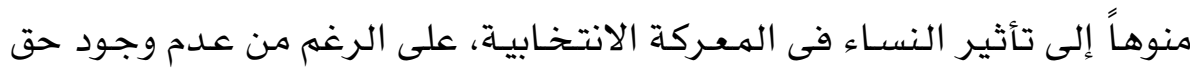

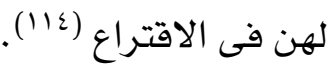

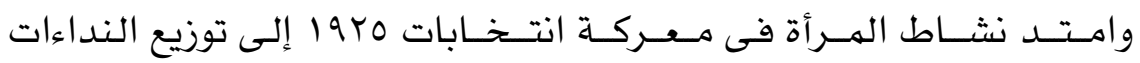

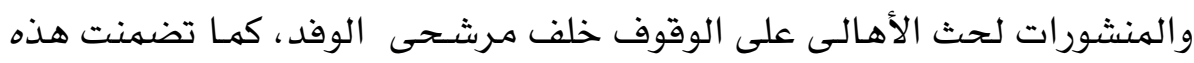

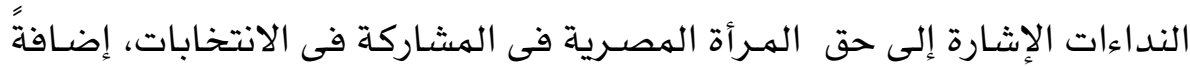


إلى انتـقــاد مـا قـام بـ زيور من تعطيل البـرلهــان، وتغـيـيــر قـانون الاتتـخــاب المباشر (110)

واهتمت لجنة السيدات السعدية بإرسـال البرقيات إلى الصحف البريطانيـة

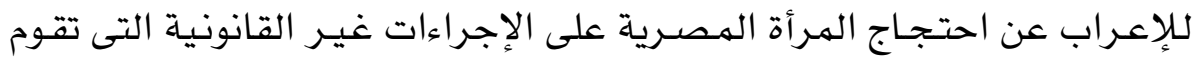

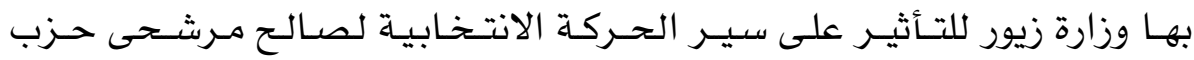

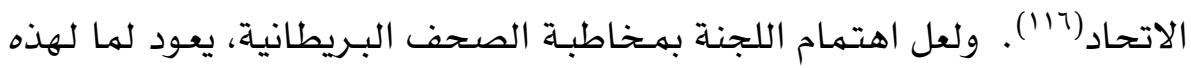

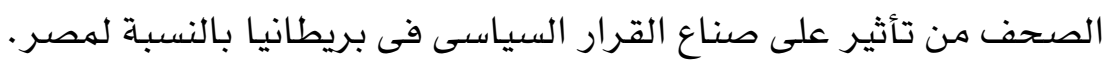
وعلى جـانب آخـر حرصت وزارة الـداخليـة على استــخــام النسـاء لـمـــاولة

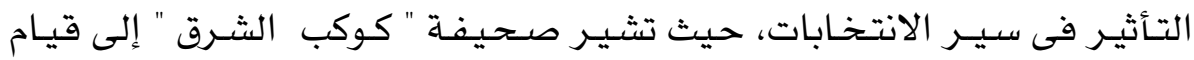

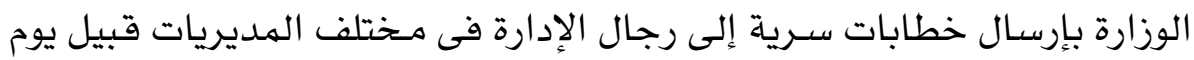

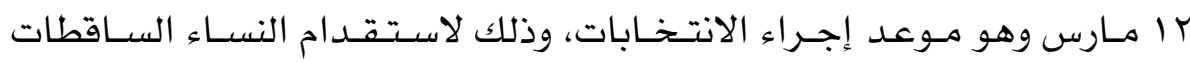

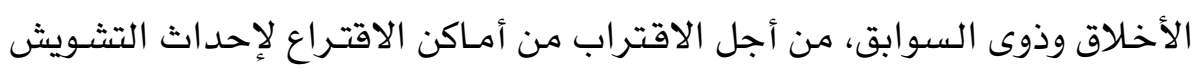
على الهندوبين (liv) وثمة مـلاحظة مهمة على مشاركة المرأة الهصرية في انتخابات 19 19، حيث

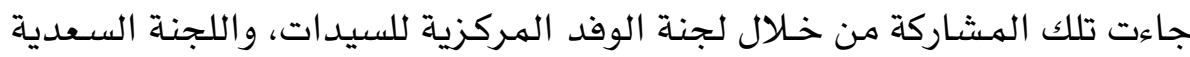

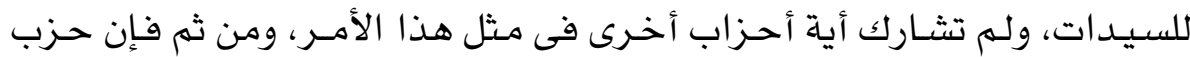

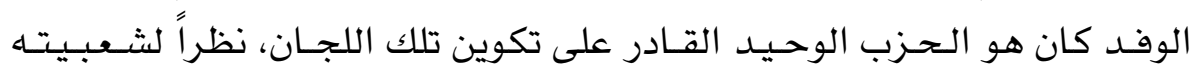
الواضحة وقدراته التظيمية الفائقة. أيضاً شهد عام 19 أظهور الهرأة الهصرية لأول مرة فى ساحة الانتخابات،

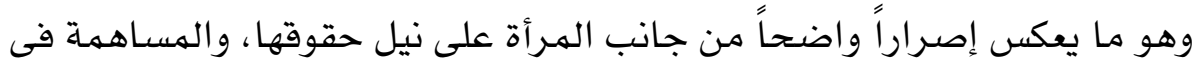
معترك الحياة السياسية. وشـاركت المـرأة فى الحركة الانتخـابيـة أثناء معـركة انتخـابات 947 1، وبدا

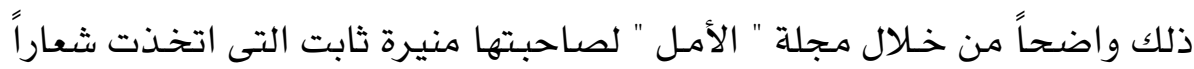

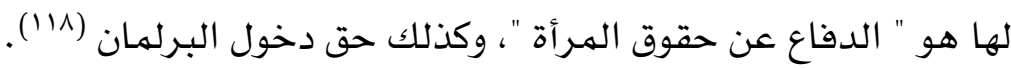

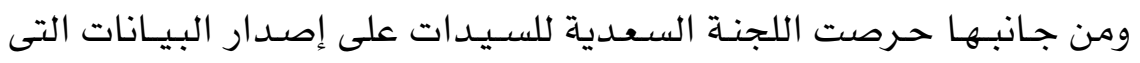


هاجمت فيها حزب الاتحـاد، مبـررةً ذلك بدور الحزب الواضـح فى تعطيل الحيـاة

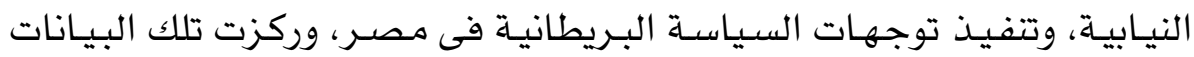

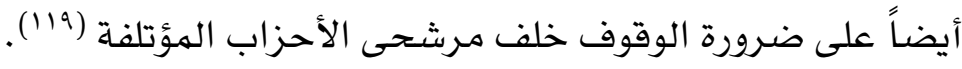

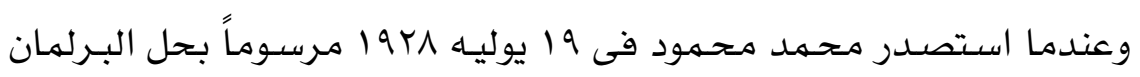

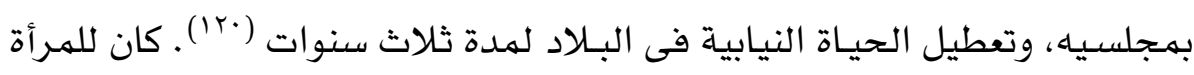

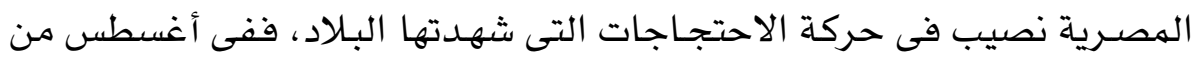

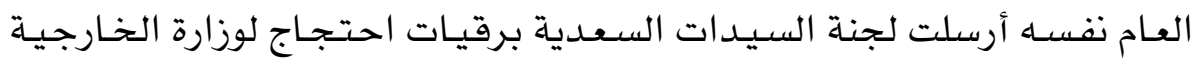

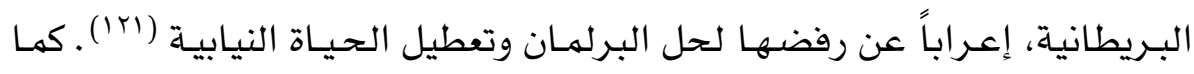

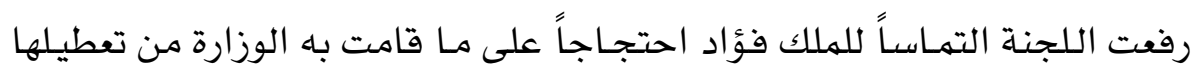

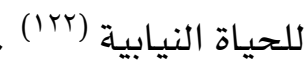

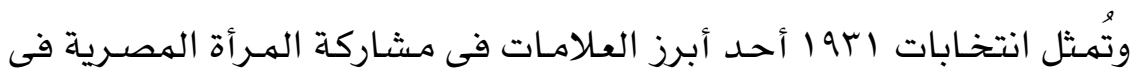

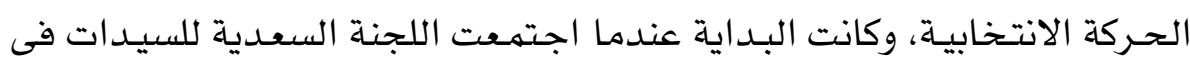

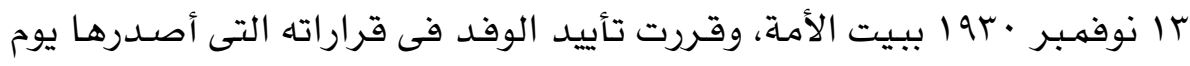

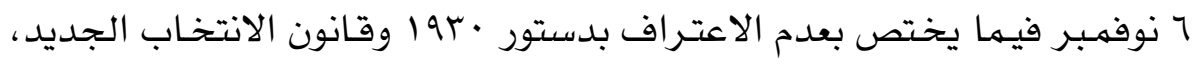

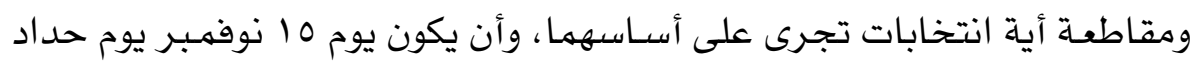

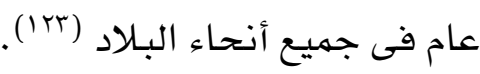

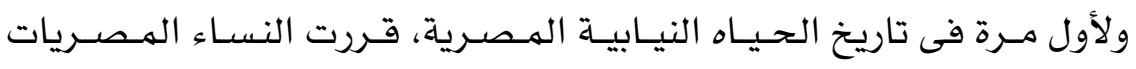

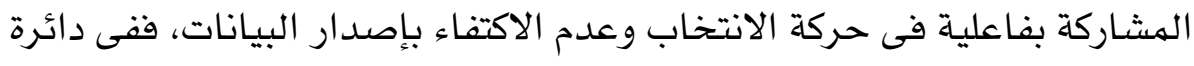

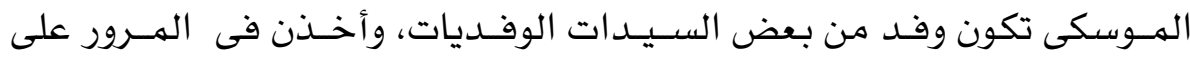
أصحاب الهحلات التحجارية والمقاهى، وذلك لحثهم على العهل بقـرار الوفد فيها

يختص بيوم الحداد، الأمر الذى أدى إلى إلقاء القبض على ولى العديد منهن (عُ1').

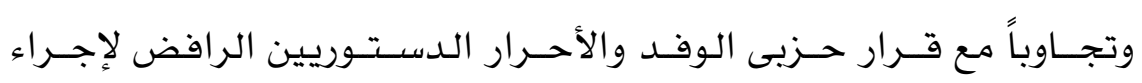

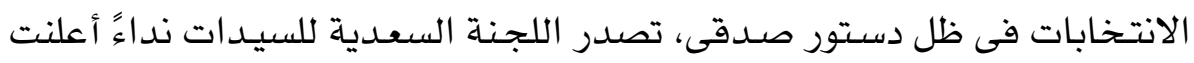

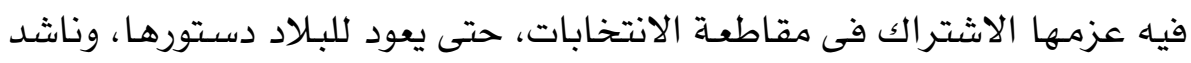


البيـان أفراد الثـعب أن يتهسكوا بحقـوقهم، ويعلنوا رفضهـهم التام لانتخـابات

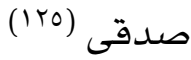

وعلى أثر منع الوفد والأحرار الدستوريين من السفر إلى طنطا فى أول مايو

ابو9 19، طاف عدد كبير من السيدات أنحاء العاصمة فى رتل طويل من السيارات

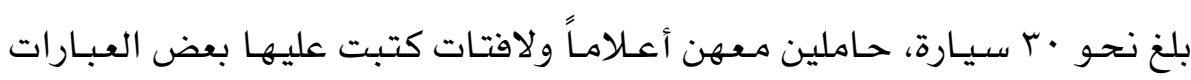
مثل: " قـاطعوا الانتخـابـات " ، "الأمـة مصدر السلطات "، وكن يهتفن للوفـد، ثم

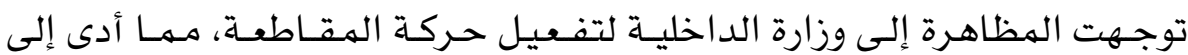
احتجاز العديد منهن، وتعرض البعض للضرب من قبـل رجال البوليس (Trارة) . ونتيجـةً لذلك أرسـلت لجنة السيـات السعدية برقية احتجـاج إلى إسـماعيل صدقى ضـد مسلك رجال البوليس، كما تم إرسال برقيـة أخرى إلى رئيس الوزراء البريطانى مكدونالد Macdonald وإلى وزير خـارجيـته هندرسن Henderson،

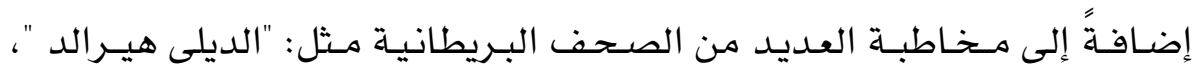

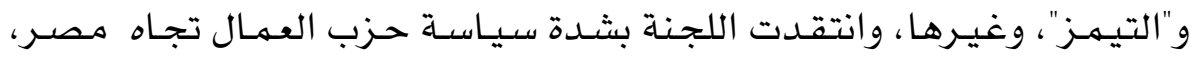

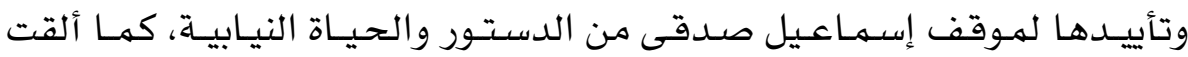

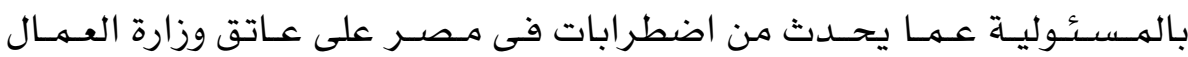

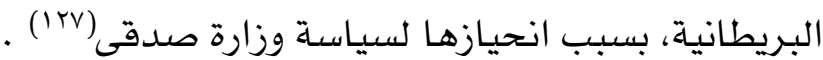

كمـا كانت البرقية رسـالة واضحة إلى الصحف البريطانيـة بأن غالبيـة أفراد

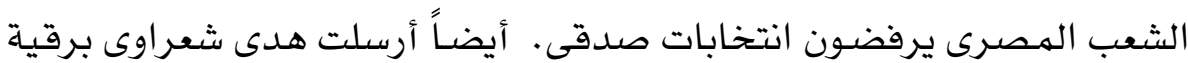

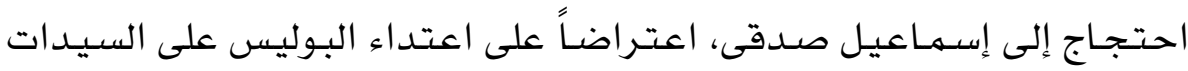

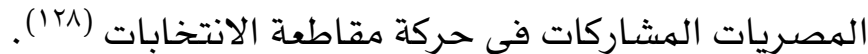

كما شـاركت هدى شعـراوى فى تظاهرة احتجـاجيـة إلى مقر وزارة الخـارجيـة

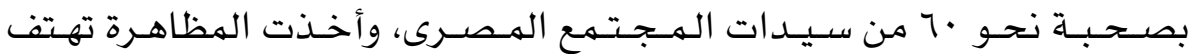

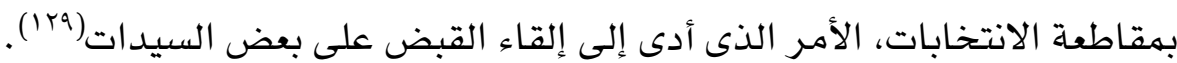


كما أعلنت نحو 9V من عضوات الجمعيات النسـائية المصرية تضـامنهن مع قرارات الهؤتمـر الوطنى التى أصسرهـا حزيا الوفد والأحرار الدستوريين فى 1

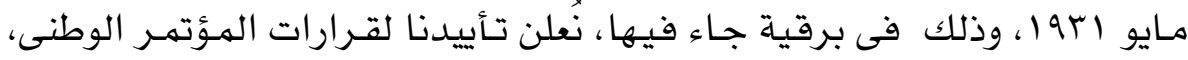

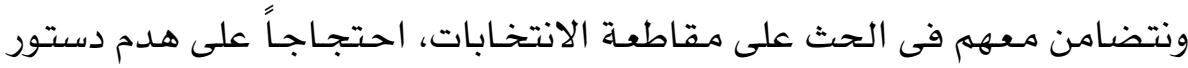
(Ir.) $19 \mathrm{rr}$

ولم تقتصر جهود الهـرأة المصرية فى مقاطعة انتخابات ابو اعلى القاهرة

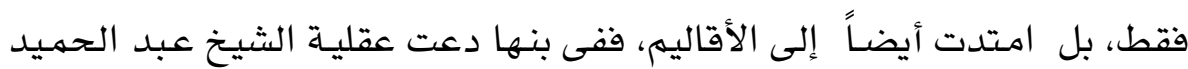
على صاحب مصنع الثلج والتبريدات إلى عقد اجتماع للجنة السيدات التهات الوفديات

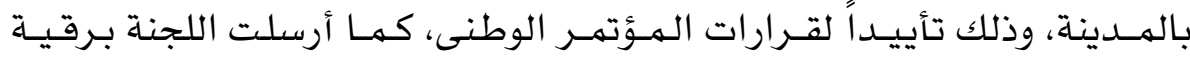

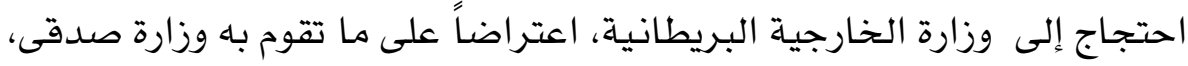

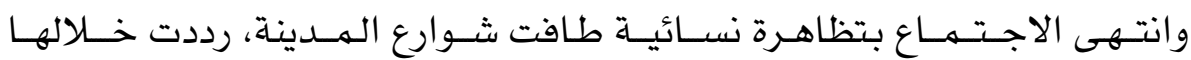

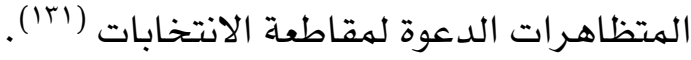
وفى بورسعيد تم عقد اجتهاع ضم العديد من سيدات وآنسات الهـدينة فى في منزل يوسـف لهيطة عضـو الهـجلس البلدى، ثم خرجن في مظاهرة بالسـيـارات

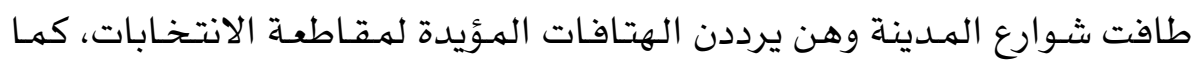

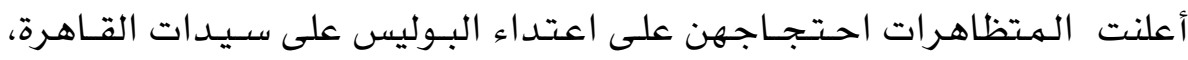
وتأييدهن لقرارات المؤتمر الوطنى (rri ).

أهـا فى طنطا فقـد رتبت سيدات الهـدينة مظاهرة خرجت فى عدة سيـارات

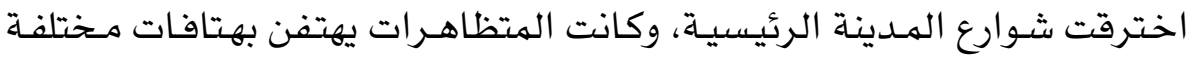

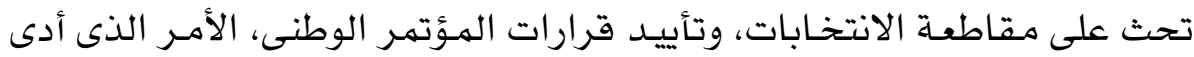

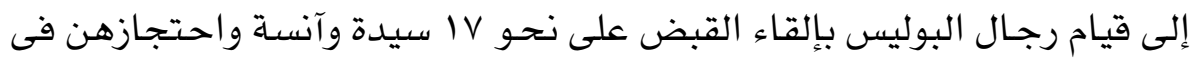

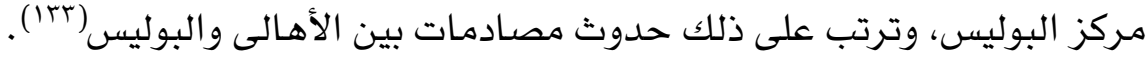
وإدراكاً من إسـماعيل صدقى بخطورة الهظاهرات وحـركة الاحتجـاجات التى وهرئ

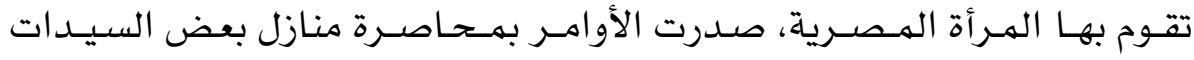


الوفديات، وعدم السهاح لهن بالخروج من منازلهن، حيث تمت محساصرة منازل:

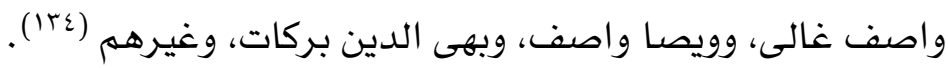
ولا شـك فى أن هذا الإجـراء كان دليـلاً على مدى النجـاح الذى حققته الهـرأة

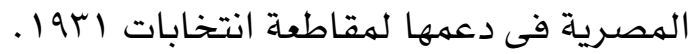
ولجـأت وزارة صـدقى إلى إسـلوب آخـر للحـد مـن مشـاركـة الهـرأة فى حـركة

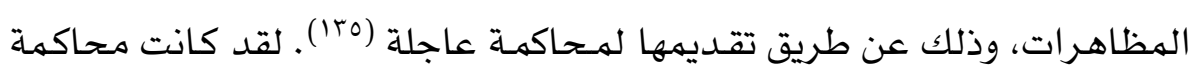

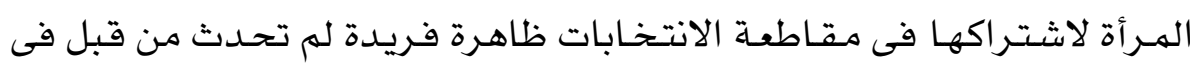
تاريخ الحياة النيابية المصرية. لتهرية. وبعد انتخابات ابس9 الم تكن هناك أية مشاركة جدية للمرأة المصرية بشأن

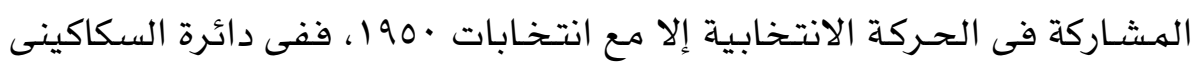

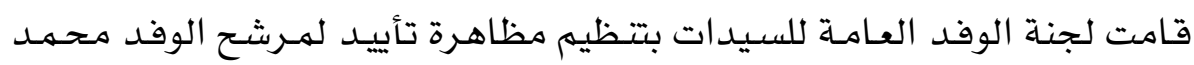

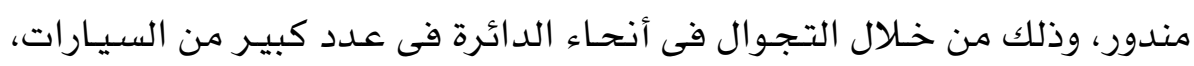

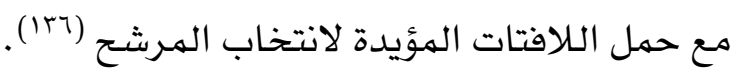

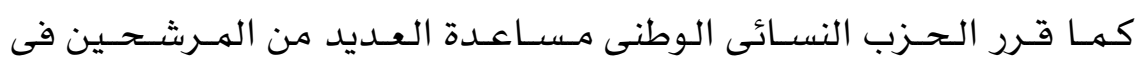

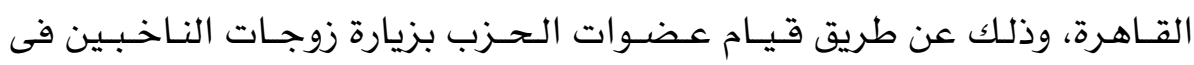

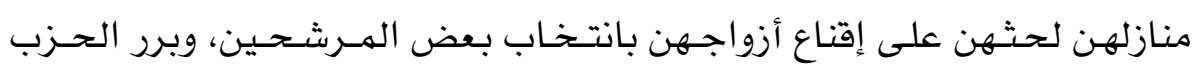

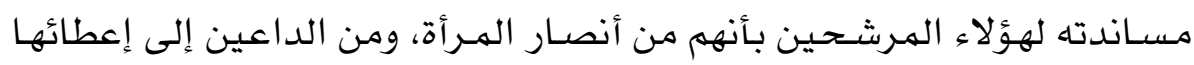

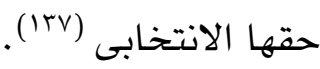

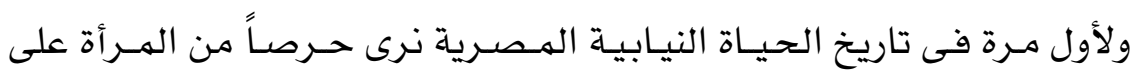

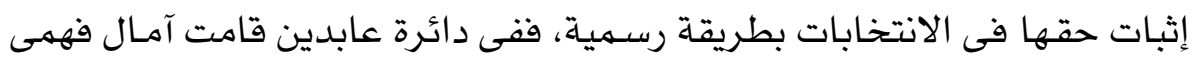

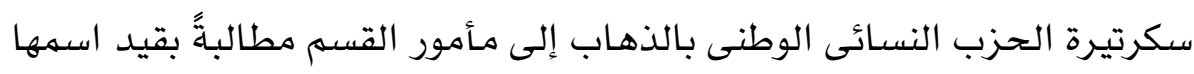

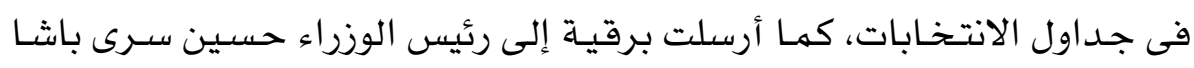

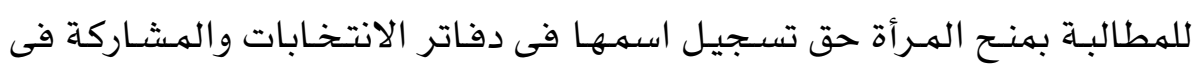


وقد تكرر هذا الأمر أثناء الاستعداد لانتخابات النواب فى أبريل 190r ، ولكن

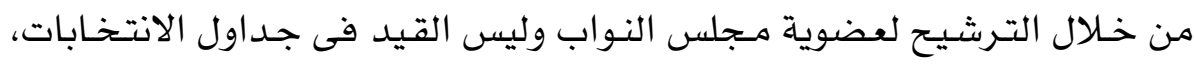

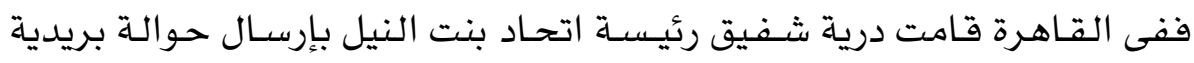

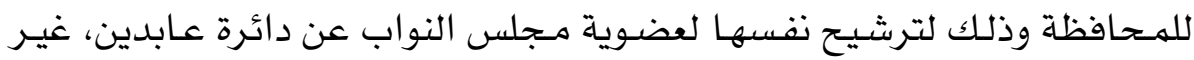

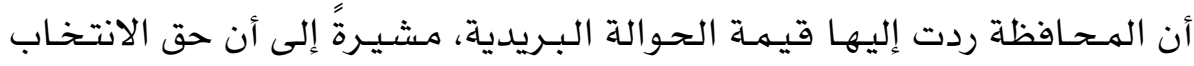

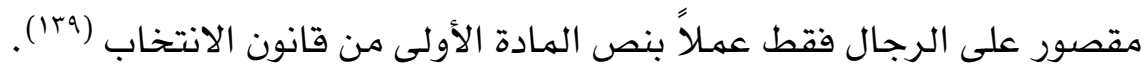
وفى الإسكندرية أرسلت السيدة ألفت السـلانكى رئيسة فرع اتحـاد بنت النيل

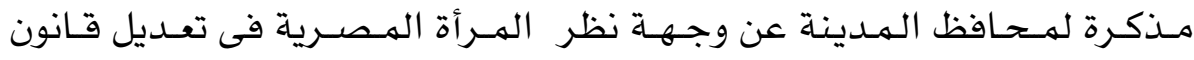

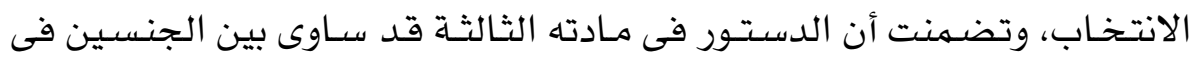

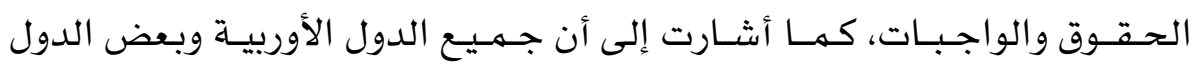

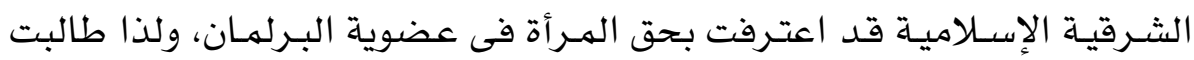

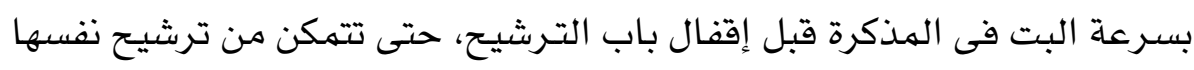

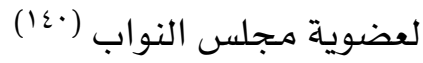

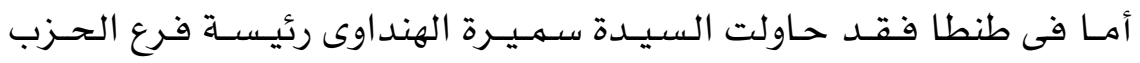

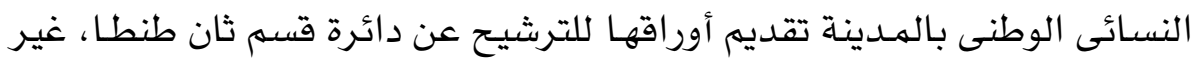

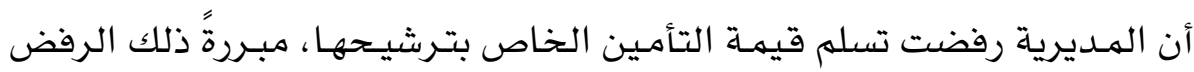

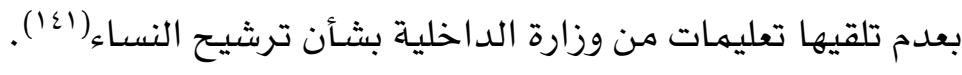
وقد أبدت فاطمة نعمت راشد عدم ارتياحها للهحاولات التى قامت بها بعض

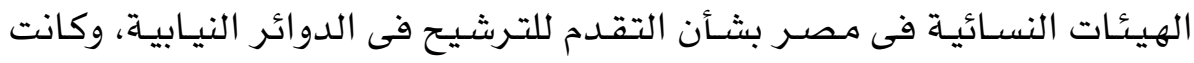

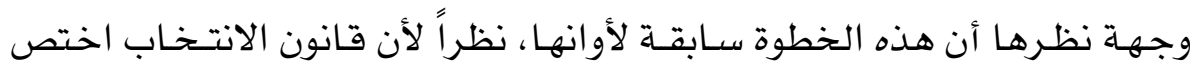

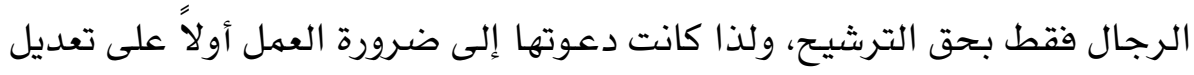

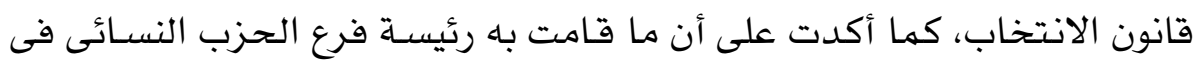

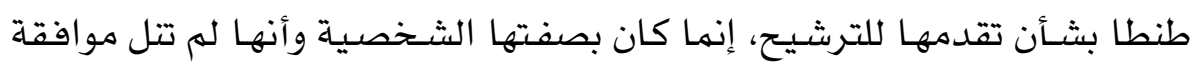

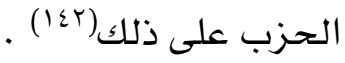


ويمكن القول بأن مشـاركة الهـرأة المصـرية فى الحـركة الانتخابية قبيل ثورة

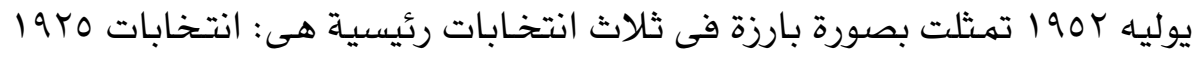

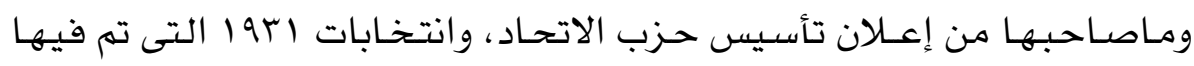

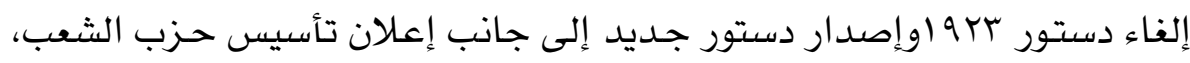

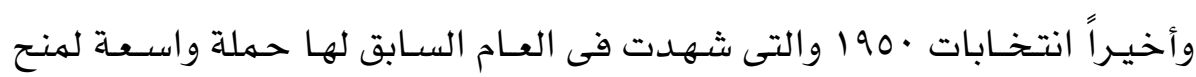

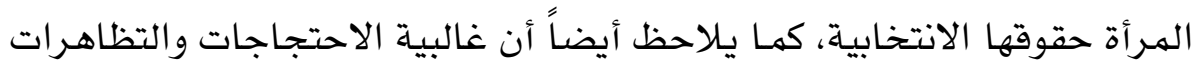
قد قامت بها سيدات المجتمع ممن ينتمين إلى الشريحة الأرستقراطية. ألمرأة الهصرية وانتخابات 190V :

فى أعقاب صدور دستور 17 يناير 1907، وإعلان الرئيس جمال عبد الناصر حق المرأة المصـرية فى الانتخاب، نظمت قيـادات الحركة النسائيـة أكبر مظاهرة

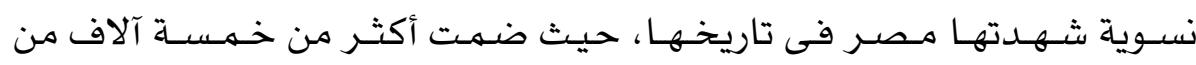

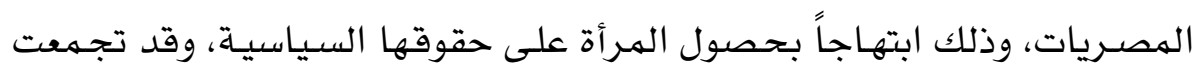

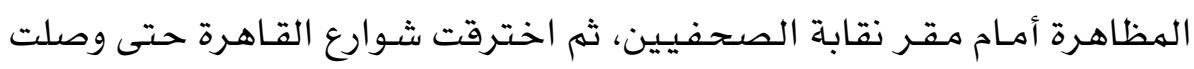

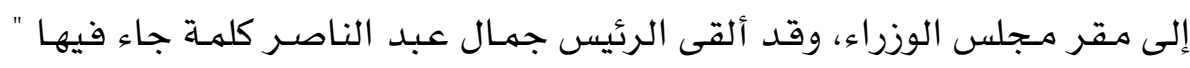

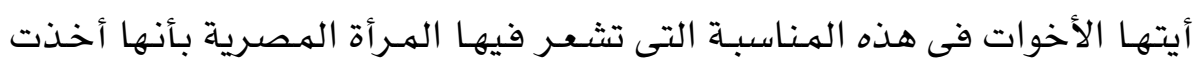

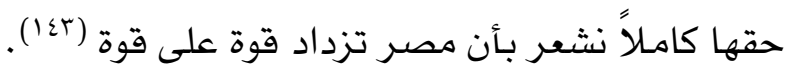

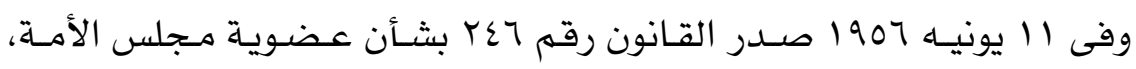

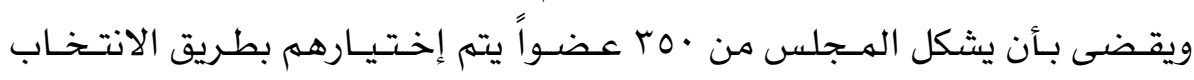

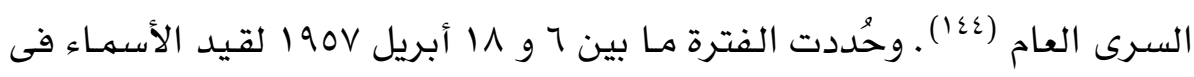

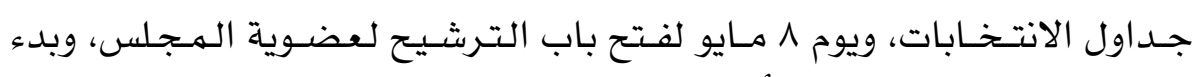

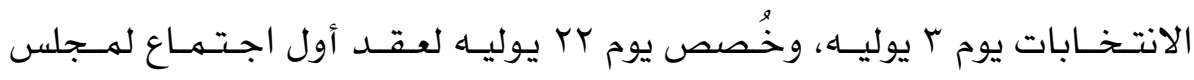

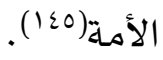

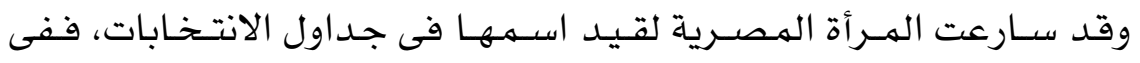

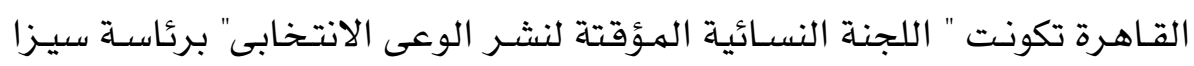


نبـراوى، وأنشـأت اللجنـة فروعـاً عديدة لها فى الأحياء الثـعبيـة، لكى تقوم بنشـر

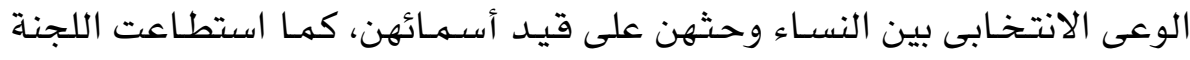

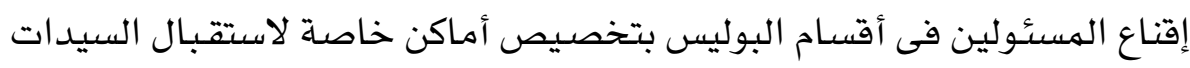

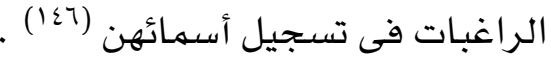

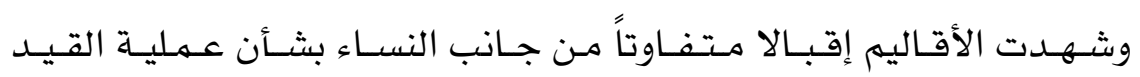

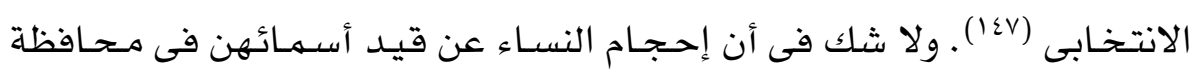

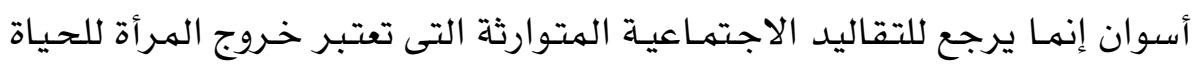

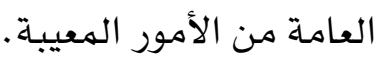
وبعد الانتهاء من عملة القيد فى الجـداول الانتخابيـة بدأت عمليـة الترشيح

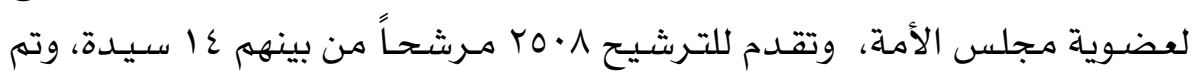

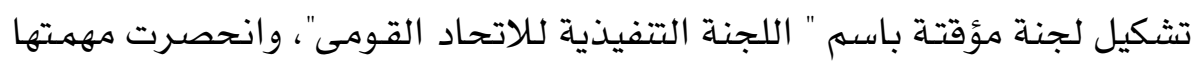

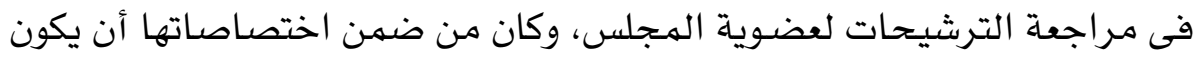

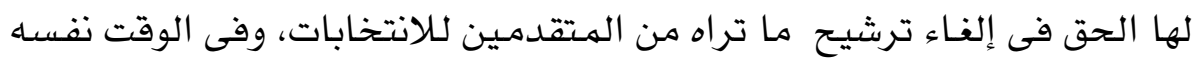

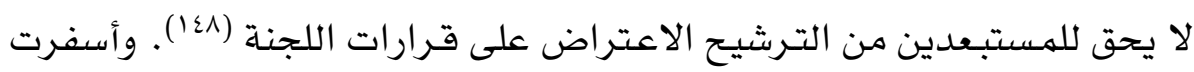

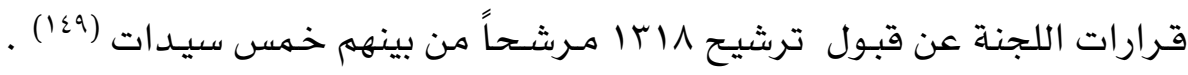

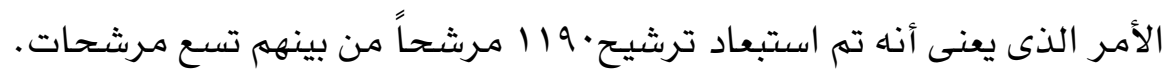
وفيما يلى بيان بالدوائر الانتخابية وأسهاء المرشحات اللاتى تم استبعادهن: - دائرة الزيتون " القاهرة" : منيرة ثابت وتم استبعادها لمصلحة وزير الإرشاد القومى فتحى رضوان الذى تم ترشيحسه فى هذه الدائرة، وجاء قرار استبعـادها فى إطار عملية تفريغ الدوائر الخاصية بالوزراء.

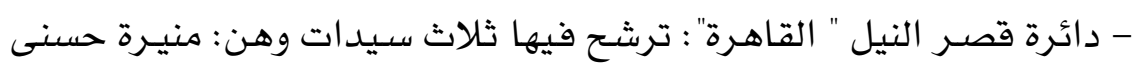
" رئيسة اتحاد نساء الدولة، وعطيات الشافعى المحامية، وليلى دوس. - دائرة الموسكى " القاهرة" : منيرة طلعت " مولدة" . 
- دائرة المعادى " القـاهرة": أمينة فههى كريم، وقد تم استبعـادها لمصلحـة وزير المالية عبد المنعم القيسونى.

- دائرة بيـلا "كفر الشيخخ": درية حمدى وهى خريجة كليـة الحقوق وتعمل فى

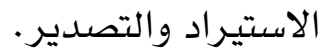

$$
\text { - الإسكندرية: توحيدة أحمـد حسن. }
$$

- دائرة إمبابة "الجيزة" : اعتدال حمودة "رئيسة اتحاد فتيات مصر" (10) . وجاء ترشيح المرأة لعضوية مجلس الأمة فى انتخابات 190V كما يلى: - دائرة ديوان قسهم بوليس مــــر القـديمـة : زينب مـراد الشـهـيـرة بـســــزا نبراوى" وكيلة الاتحاد النسائى.

- دائرة باب شرق بالإسكندرية: أمنية محممد أبو العز والمعروفة باسهم أمينة شكرى عضو اتحاد بنت النيل ورئيسة جمعية صديقات الطفولة. - دائرة ديوان قـسم الجـيـزة رقمبر : راوية عطيـة شـمس الدين مــدرســة

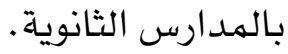

- دائرة كرداسة "الجيزة" : زينات حافظ عابدين " رية منزل". - دائرة بلقاس "الدقهلية" : نظلة عبد الله الحكيم (101) . ويتبيـن من هذه الترشيـحات سـواء التى تم رفضها أو قبولها عدم وجود أية

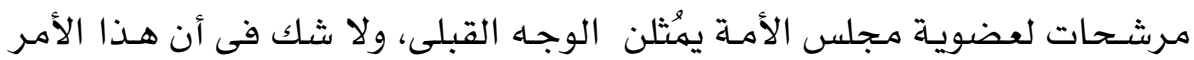

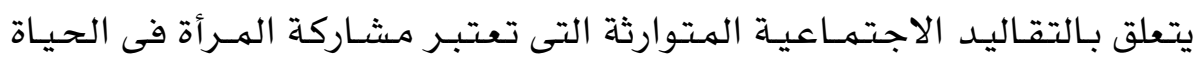
السياسية من الأمور غير اللائقة اجتماعياً. ولعل مـا يدعم هذا الرأى ما حـدث مع السيـدة سنية طه "مـدرسـة لغـة عريبية"

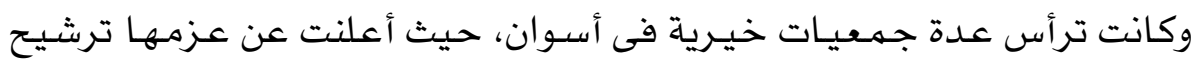

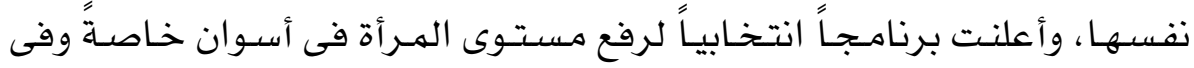




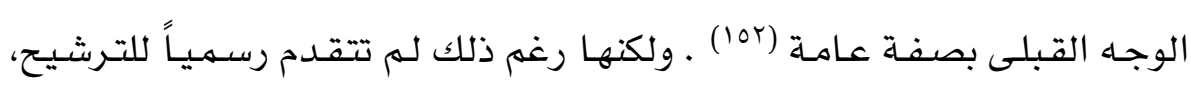

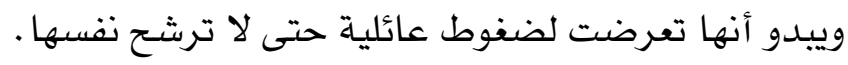
وقــ تكرر هذا الأمـر فى دائرة أولاد إليـاس بأسـيـوط، حـيث أعلنت إحـدى

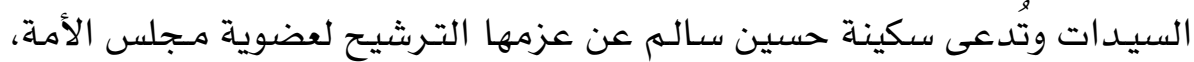
وبالفعل توجهت قبيل إغلاق باب الترشيح بيوم إلى مديرية أسيوط لدفع التأمين،

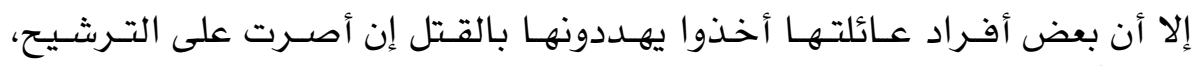

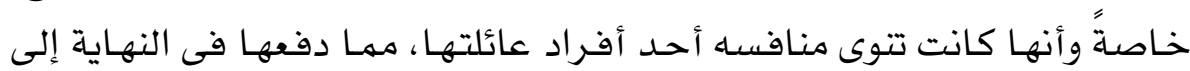

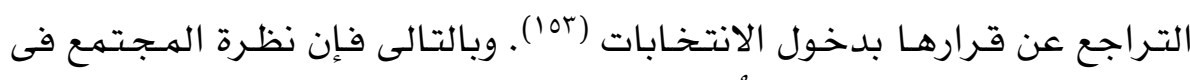

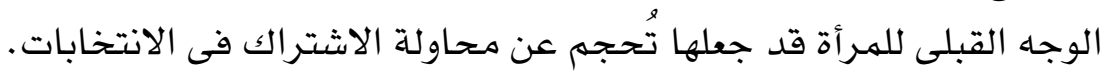

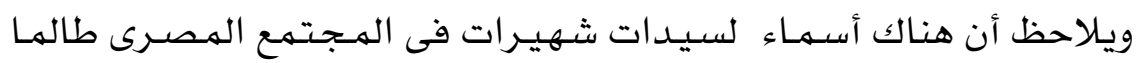

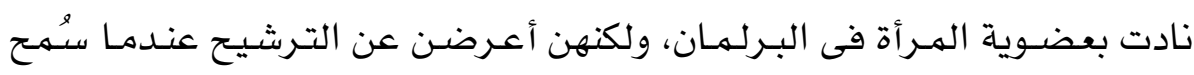

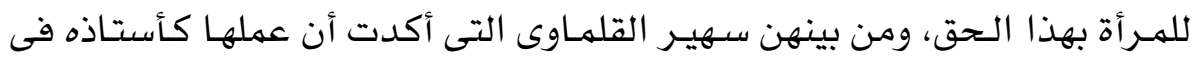

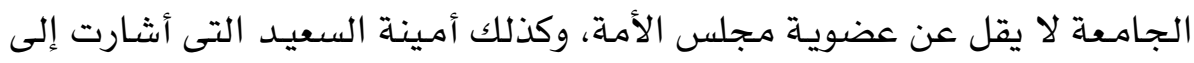

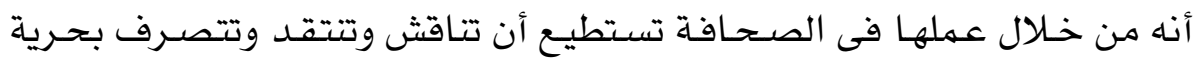

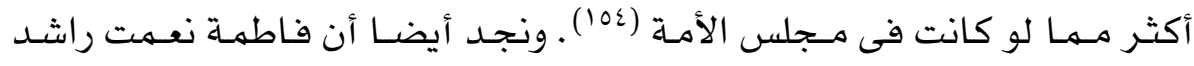

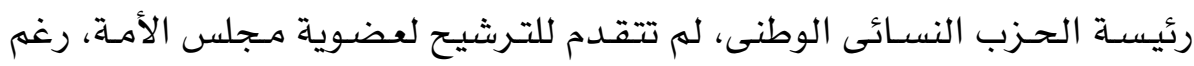

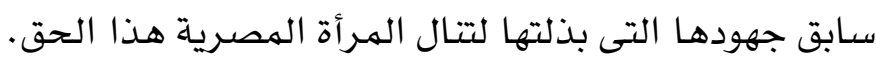
على جـانب آخـر كـانت هناك سـيـــات من المـــافـــات عـن حـــوق الهـرأة

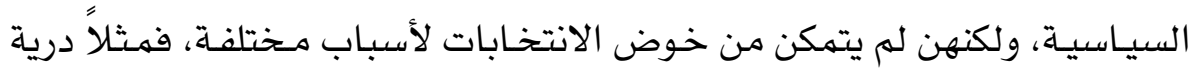

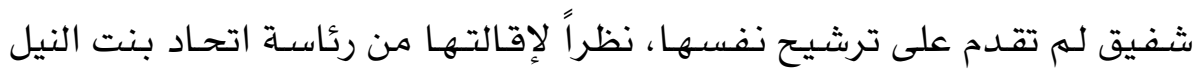

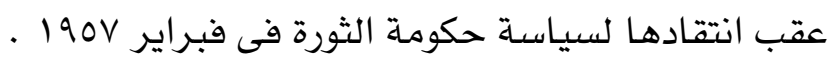
وهناك من الهـرشتحات من تقدمن للترشيح لأغراض أخرى غير رغبتهن فى

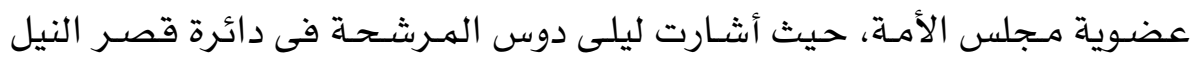
إلى رغبتها فى تأييد الكاتب الصحفى موسى صبرى رئيس تحرير "مجلة الجيل" 
الذى ترشتح فى هذه الدائرة، وبررت الأمر باقتناعها بأنه أصلح من يخدم مصالح

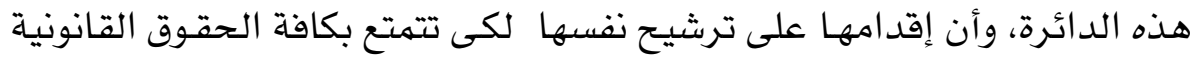

التى تكفل لها استخدام وسائل الدعاية الانتخابية لصالح موسى صبرى لرئى (100). وحرصت غـالبية المـرشتحات على وضع برامج انتخابية خـاصـة بهن، فمثلاً

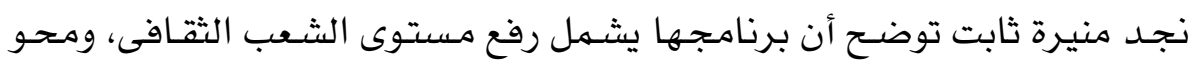

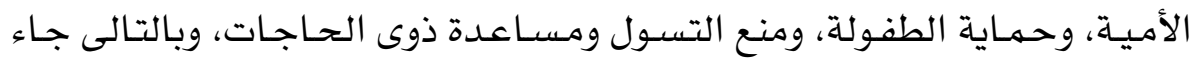
معظم برنامجها الانتخابى متتاولاً النواحى الاجتماعية.

وتبنت درية حـمـدى مـرشـحـة بيـلا مبـدأ التوسع فى التصنيع بـائرتها وذلك

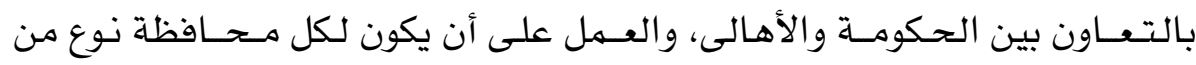

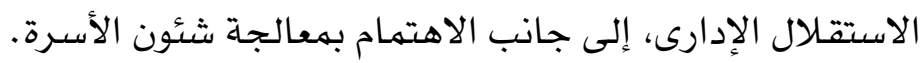

وركزت راوية عطيـة فى برنامجهها على الجـانب السيـاسى بصـورة واضحـة،

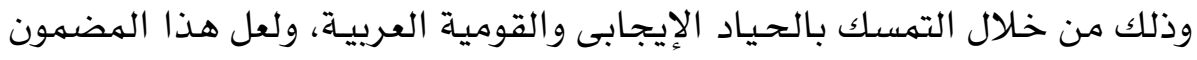

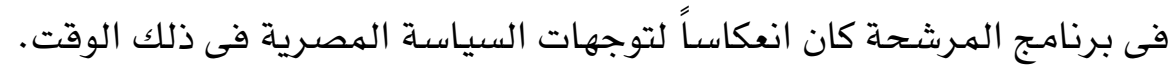
وجاء برنامج عطيات الشافعى متتاولاً العديد من الجوانب الاجتماعية مثل

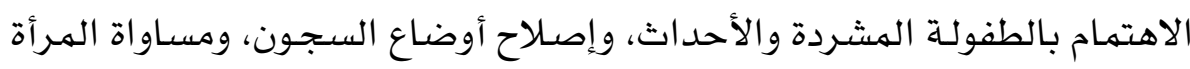
بالرجل فى العقوبات، وتمييزها فى قانون العمل (107) .

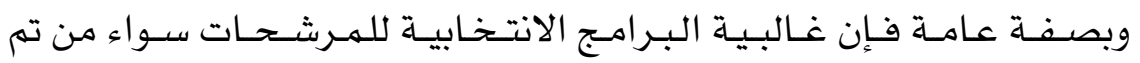

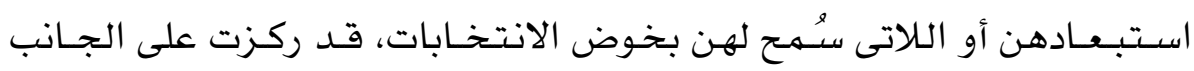

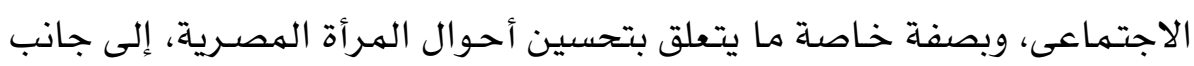
الاهتمام بالطفولة. وقد تتوعت وسـائل الدعاية الانتخابيـة من قبل المرشتحات، فمثيلاً فى دائرة

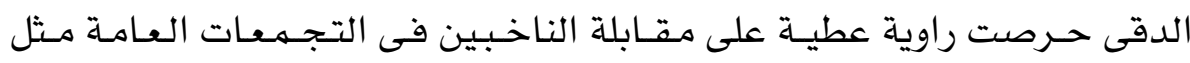

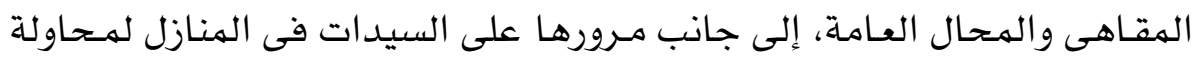

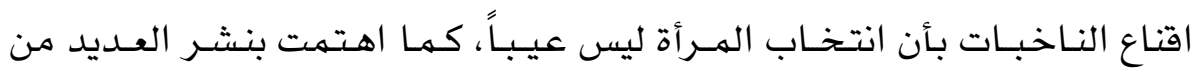


لافتات الدعاية في مختلف أنحاء الدائرة والتى حملت شعارات مختلفة كان من بينها على سبيل المثال "زلزلوا الرجعية بانتخاب أختكم الثائرة راوية عطية" (10V)

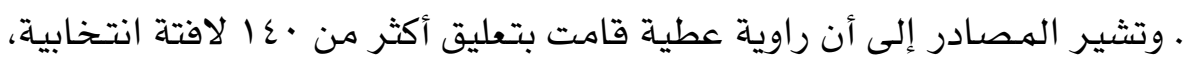

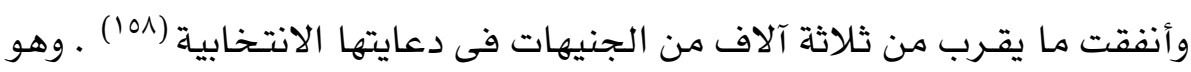

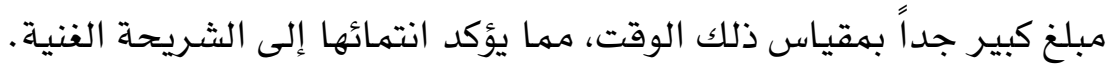
وفى دائرة قصر النيل لجأت عطيات الثافعى فى دعايتها الانتخابية بخلاف

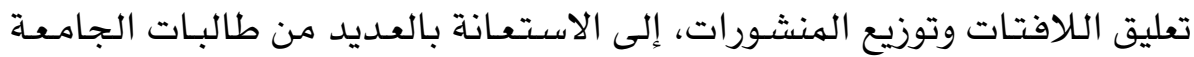

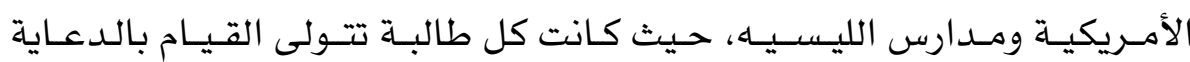
الانتخابية للهرشحة في أحد شوارع الدائرة الرئيسية (109) . ومن أطراف وسـائل الدعاية الانتخابية مـا حدث فى دائرة بيـلا، حيث لجـأت الهـرشتحـة درية حهـدى إلى توزيع أكياس من الشـاى والسكر على الفـلاحين، وكل

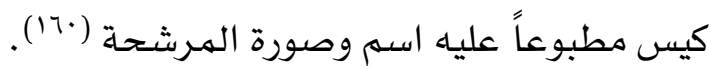

واهتمت بعض المـرشـحـات بإقـامـة مؤتمــرات انتخـابيـة كوسيلة من وسـائل الدعايـة الفعالة، ففى دائرة مصـر القديمـة تم إقامـة مؤتمـر انتخـابى كبير لتأييد الهـرشـحـة ســـزا نبـراوى، وتم دعـوة العـديد من الشـخصـيـات مـــن يؤيدون فكرة

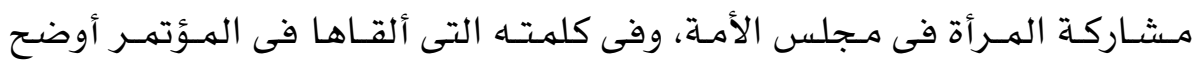

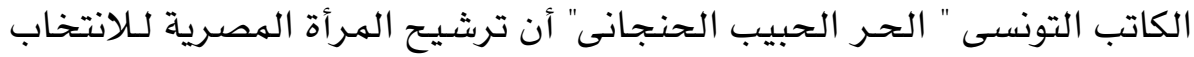

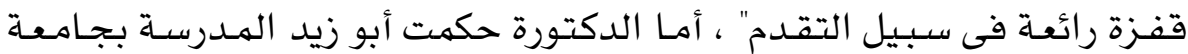

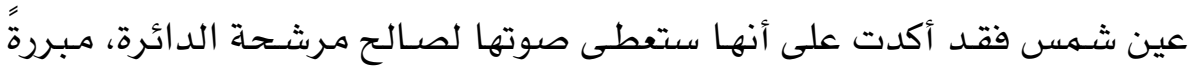

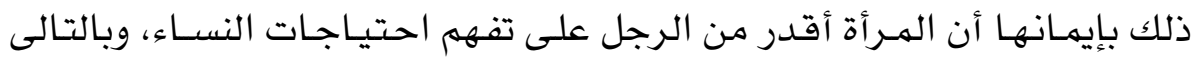

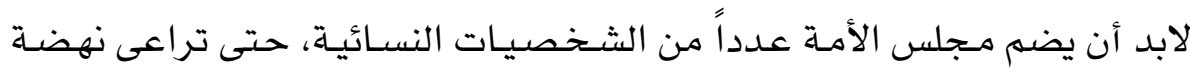

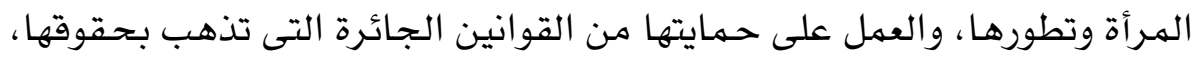

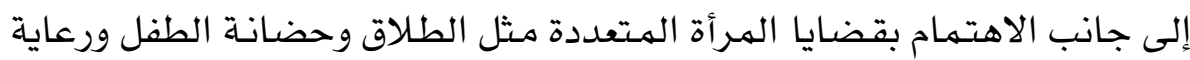

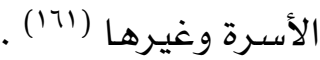


وبصفـة عامة فإن غالبية الهرشحات لعضوية مجلس الأمـة قد اعتمدن على

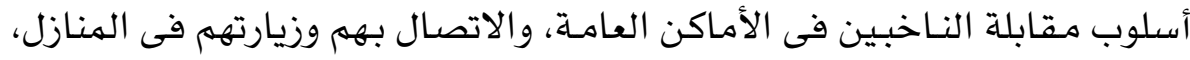
إلى جانب طبع المنشورات وتعليق اللافتات التى تشرح برامجهن الانتخابية. وكـذلك كـانت هناك بعض الجهـود الجـهـاعـيـة لدعم الهـرأة فى مـــركتهــا

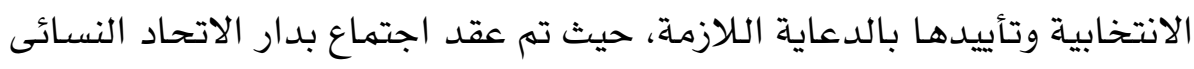

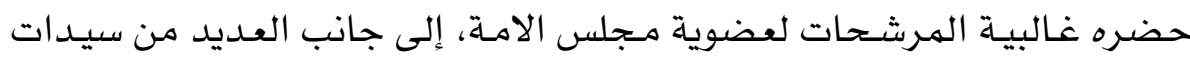

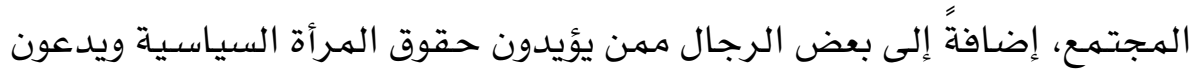

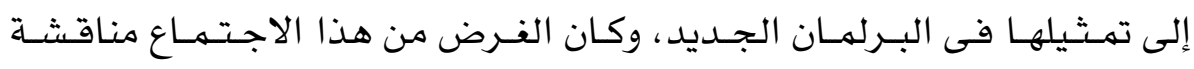

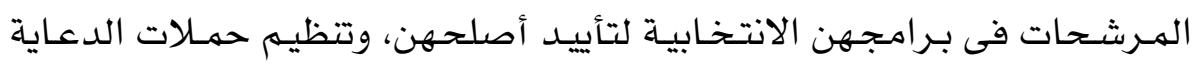

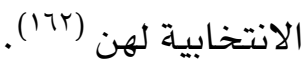

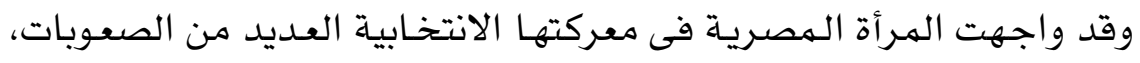

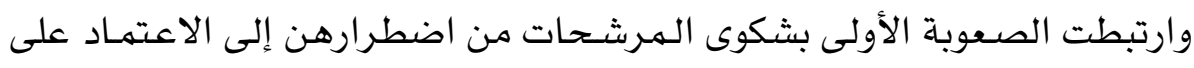

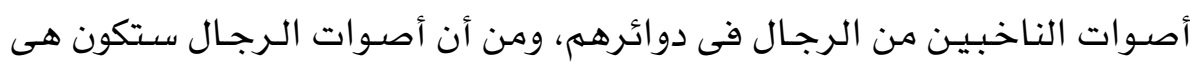

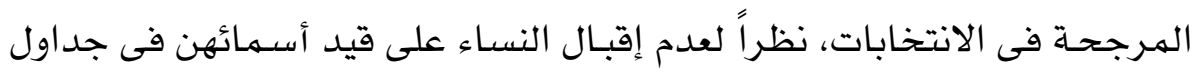

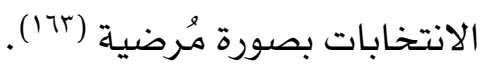
أمـا الصعوبة الثانيـة فـارتبطت بنظرة المــتمع لفكرة اقتحـام المرأة لمجـال

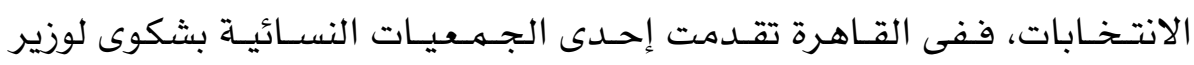

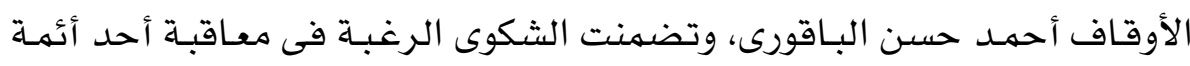

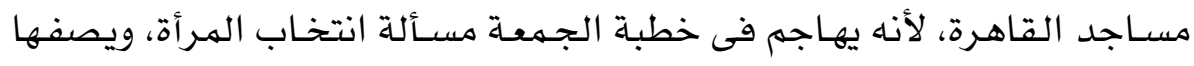

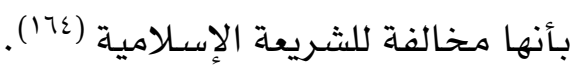

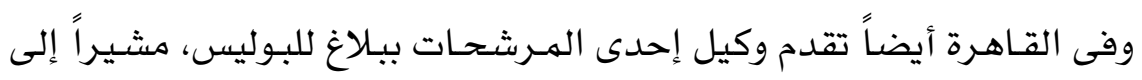

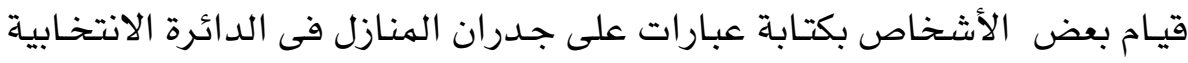

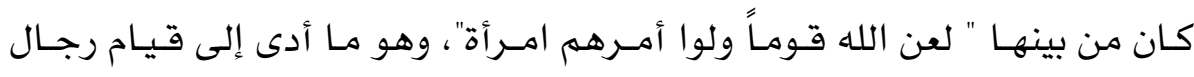

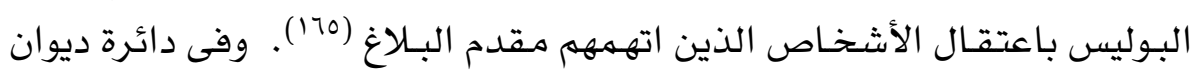




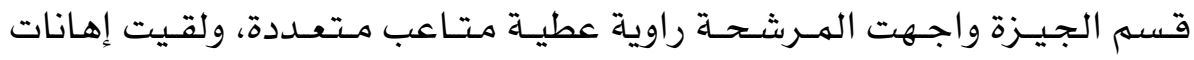
وشتائم وأغُلقت أبواب العديد من المنازل فى وجهها، وسهعت عبـارات غير لائقة

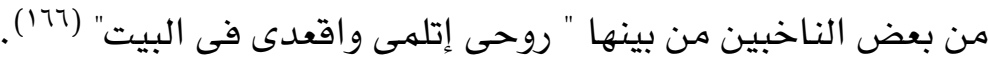
أهـا المرشتحة توحيدة حسن فكانت تثكو من أن المـرشحين المنافسين لها

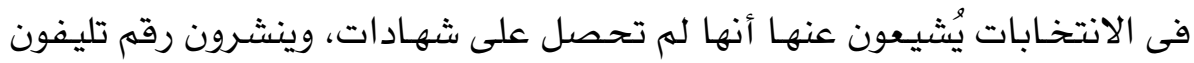

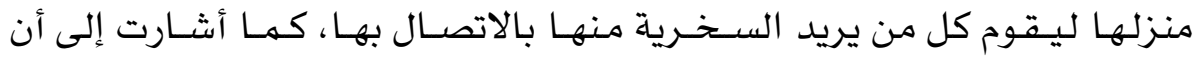

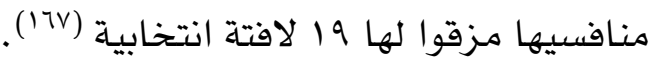

وفى دائرة كرداسـة تقدمت المـرشـحـة زينات حـافظ عـابدين ببـلاغ إلى نيابة

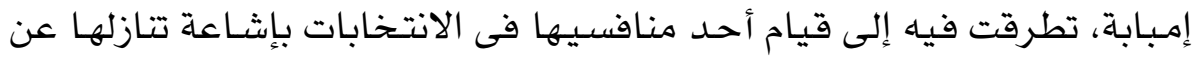
ترشيح نفسها، وذلك بواسطة مكبر صـوت فى سيـارة ظلت تطوف أنحـاء الدائرة

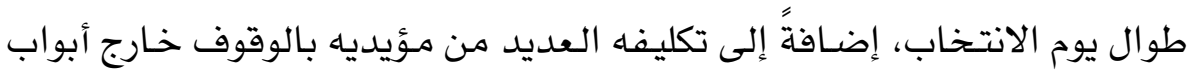

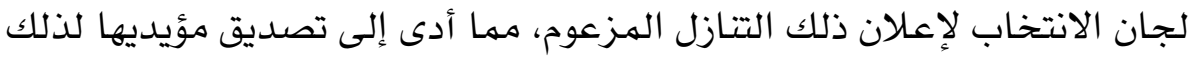

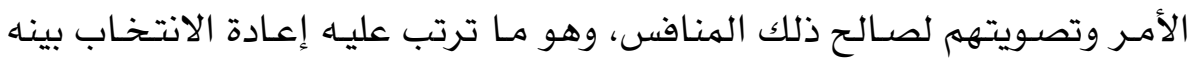
وبين مرشتح أخر (171) .

ولا شـك فى أن تلك التجاوزات التى مورست ضد المرشحات لعضوية مجلس

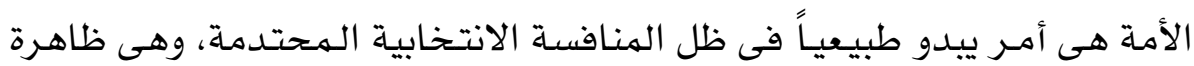

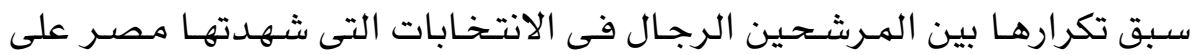
مدار تاريخها منذ انتخابات عب91، هذا إلى جانب نظرة الاستهجان التى أبداهـا

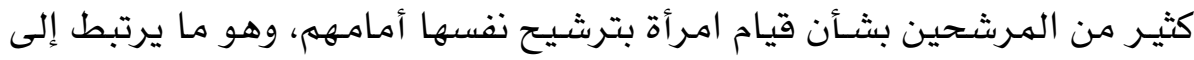
حد كبير بنظرة المجتمع للمرأة في هذا الثنأن. وعلى أية حـال فقــ جـاءت نتيـجة انتخـاب المرشـحات لعضـوية مجلس الأمـة فى ץ يوليو 190V كما يبين الجدول التالى (179) 


\begin{tabular}{|c|c|c|c|c|c|}
\hline النتيـجـة & الأصبوات المئوية & |الأصوات التى المصرشت عليها & التصى الصحيحة أعطيت & أسماء المرشـحين & الدائرة الانتخابية \\
\hline لهم تقز & $\% 19,9$ & rYAT & 11989 & سيز انبراوى & ديوان قسهم مصر \\
\hline إعادة & $\% r V, 0$ & OITY & INTKT & راوية عطية شسمس & ديوان قسم الجيزة \\
\hline لم تفز & $\%, 0$ & $7 \varepsilon V$ & INE7r & |زينات حافظ عابدين & كرداسة (الجيزة)) \\
\hline إعادة & $\% \varepsilon r, \varepsilon$ & $009 r$ & IrAOA & أمينة محمد أبو العز & (الإسكندرية شـرق ) \\
\hline للم تقز & $\% r, 9$ & OOr & invor & نظلة عبد اللها & "مركز بلقاس \\
\hline
\end{tabular}

وفى انتخـابات الإعـادة التى جـرت فى عا يوليه 190V تمكنت الهـرشحـتان البـاقيتان للإعـادة من تحقيق الفوز، ففى دائرة ديوان قسهم الجيزة حصلت راوية

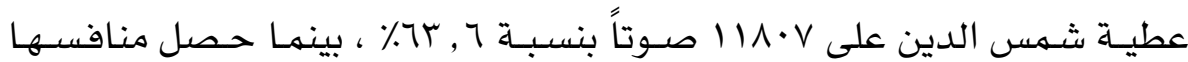

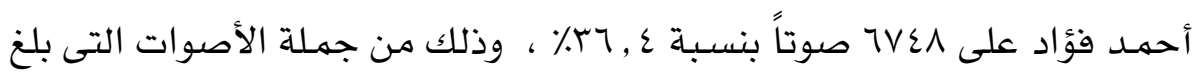

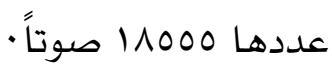

وفى دائرة قسهم باب شـرق بالإسكندرية استطاعت أمينة محسمد أبو العز أن

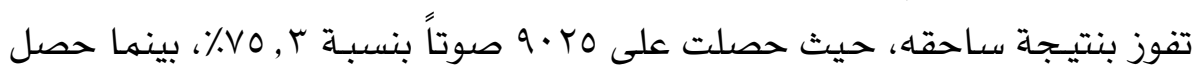

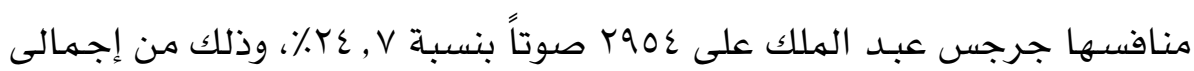

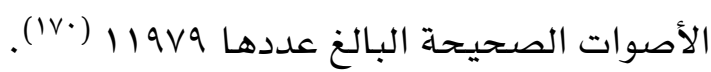

وبهذه النتيجـة استطاعت المـرأة المصـرية لأول مرة فى تاريخها أن تحصل

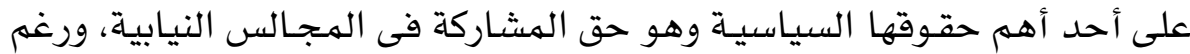

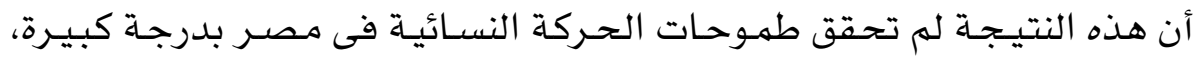

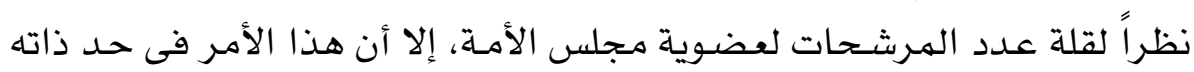

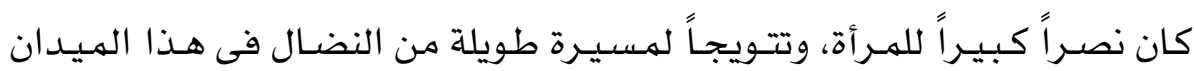

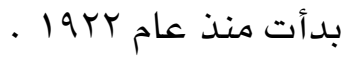




\section{الخخاتمهة}

يتـبـين من خـلالهـا هـذه الدراسـة مـدى التبـاين الشــديد في الآراء حـول منح

الهـرأة حق الانتخـاب، حيث كانت البداية فى الاعتراض على عدم مشاركتها فى في

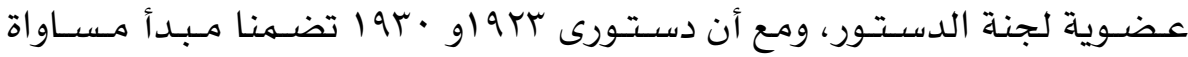
المصريين أمام القانون، مع تمتعهم بكافة الحقوق السياسية والمدنية دون تمييز،

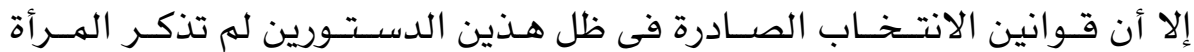

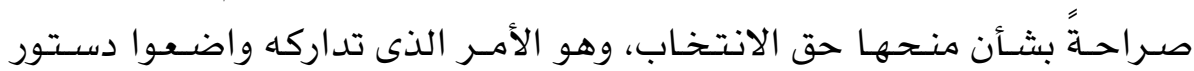
1907، وقانون الانتخاب الصادر فى العام نفسهـ.

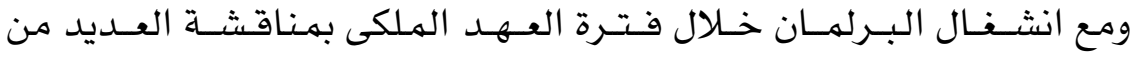

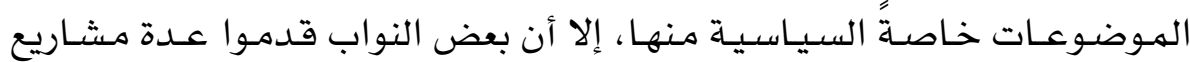

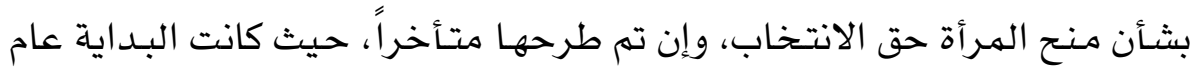

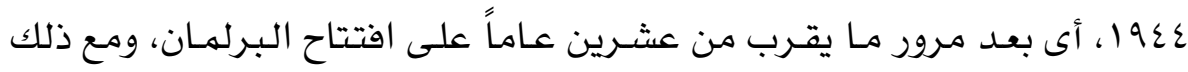

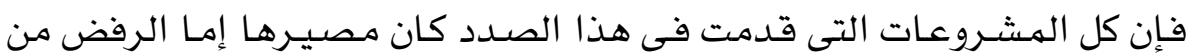

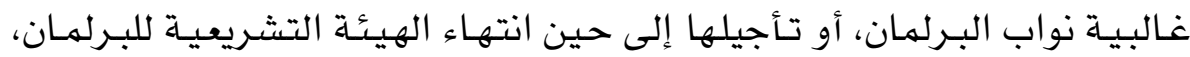

$$
\text { وبالتالى عدم الفصل فيها . }
$$

ولا شك فى أن نظرة المجتمع المصرى لمبـدأ المشـاركة الانتخـابية للهـرأة

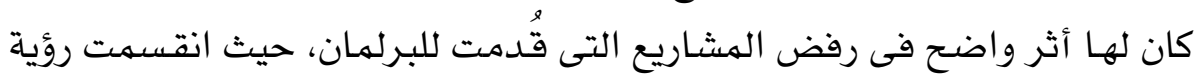

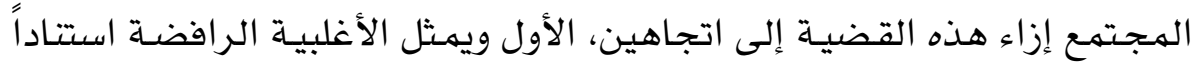

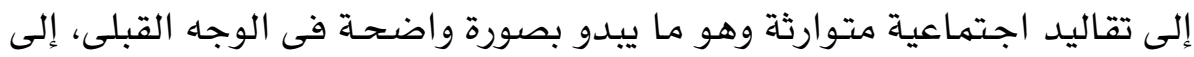

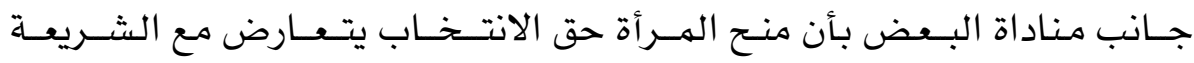

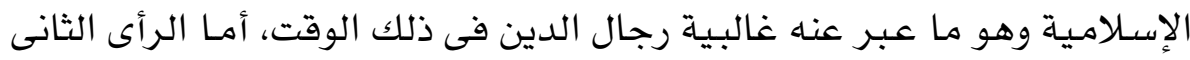

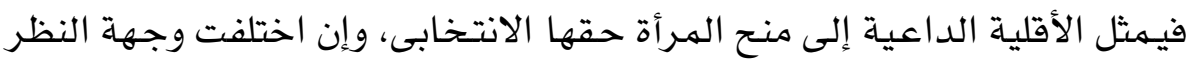

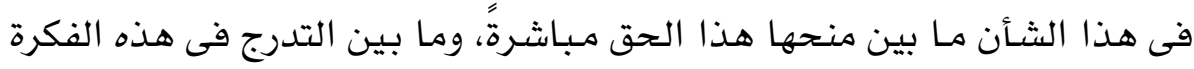
لتهيئة المجتمع وتقبله لها. 
وفى ظل ذلك التـافس الثـديد بين الأحـزاب الهصـرية للوصـول إلى مقاليـد

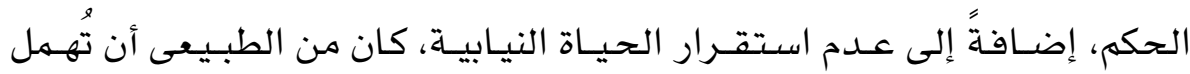

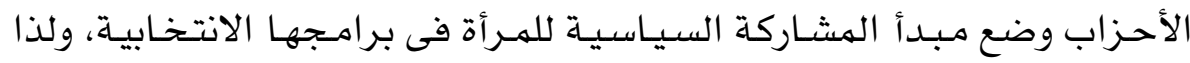

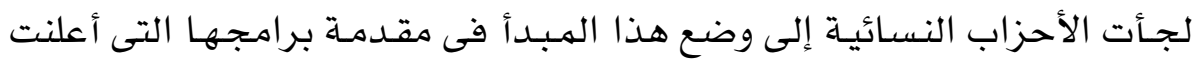
عنها، في محاولة جادة منها لتمكين الهرأة من الحصول على حق الانتخاب. وكان لقيادات الحركة النسـائية دور فعـال فى إثارة هذه القضيـة باستهـرار،

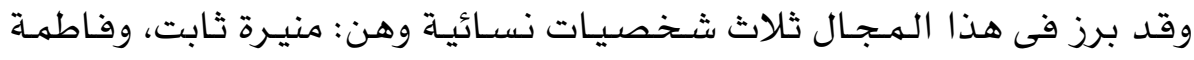

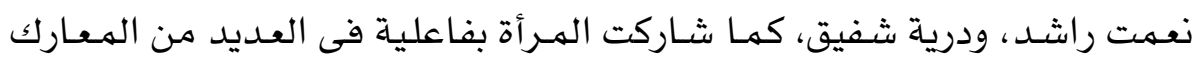

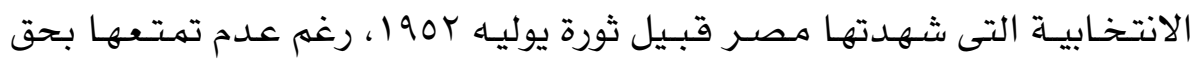

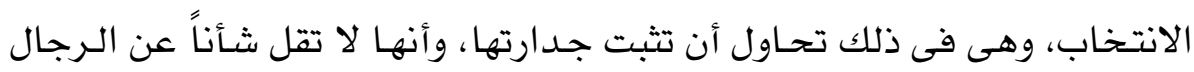

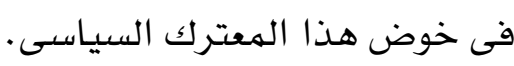
ويجب أن نُشير إلى أن المرأة المصرية قد بذلت جهوداً كبيرة لكى تتمكن من

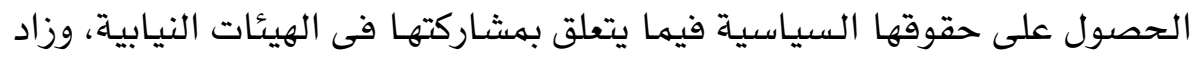

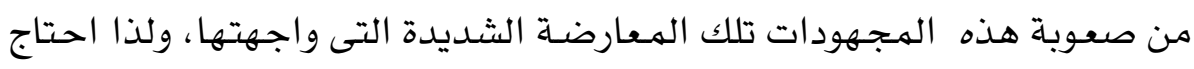

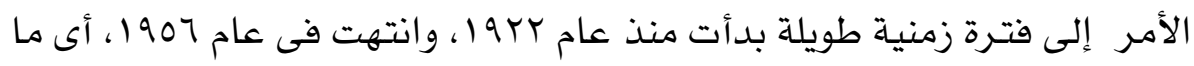

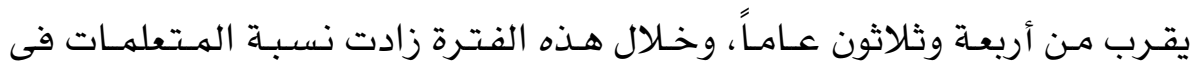

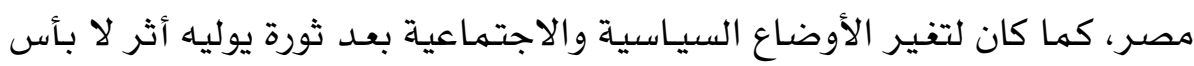

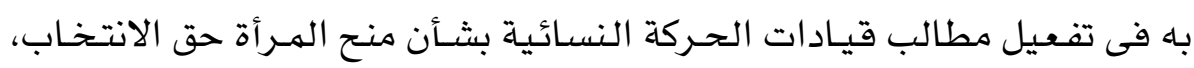

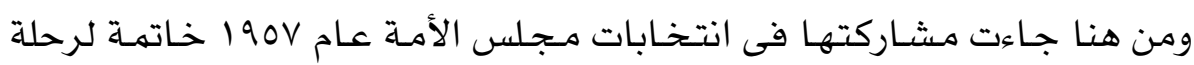
كفاح شاقة من أجل حصولها هلى على حق التمثيل النيابى. 


\section{الهوامش}

Royal institute of international Affairs, Great Britain and Egypt 1914- 1951, (1) London, 1957,P.9.

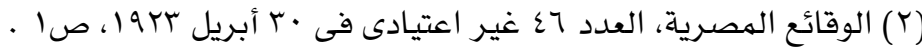

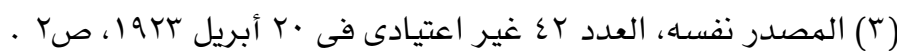

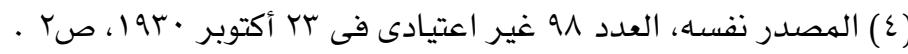

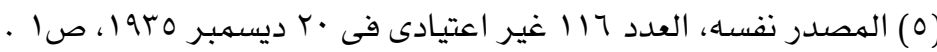

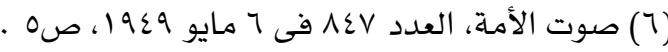

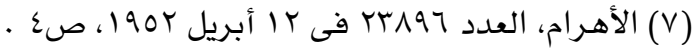

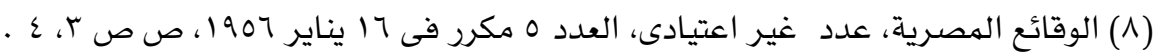

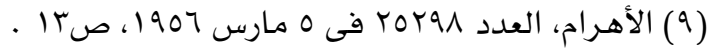

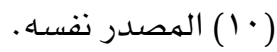

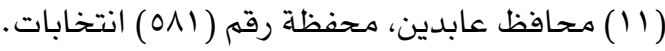

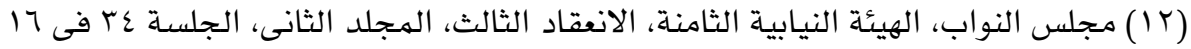

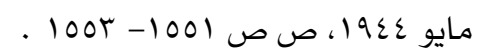

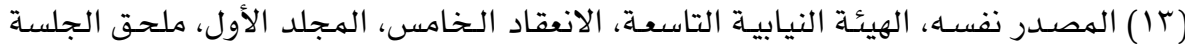

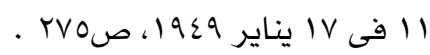

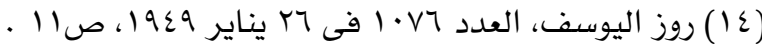

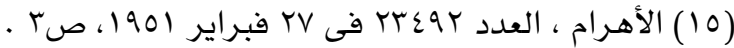

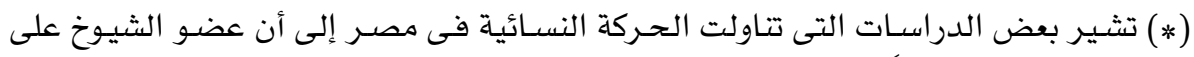

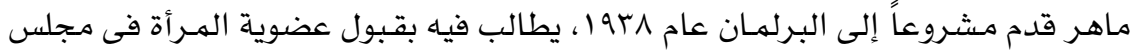

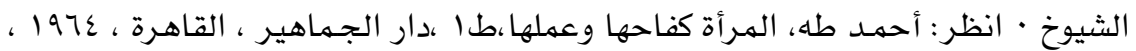

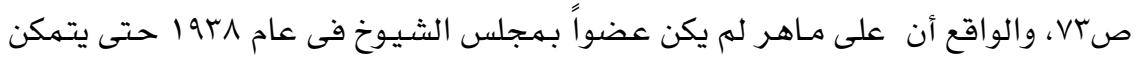

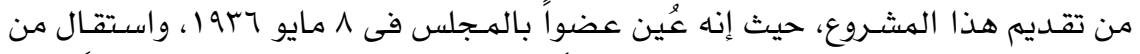

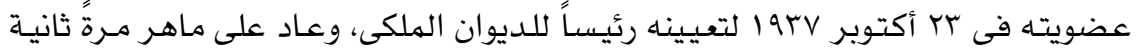

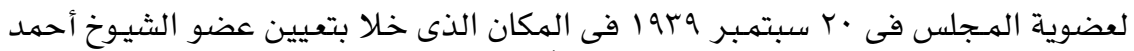

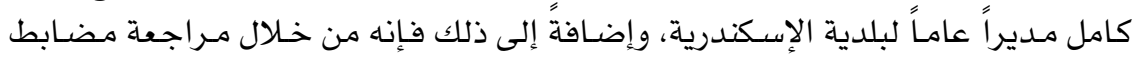

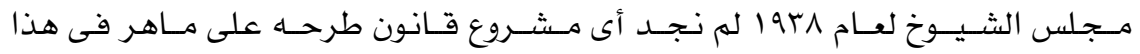

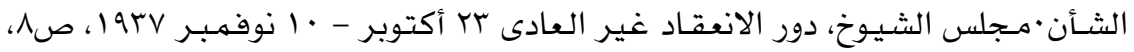

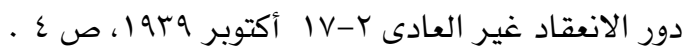

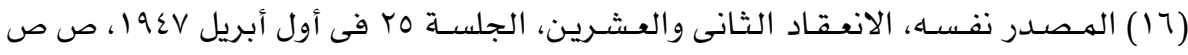




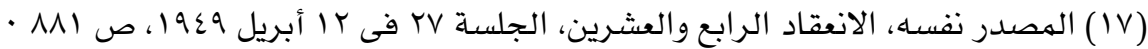

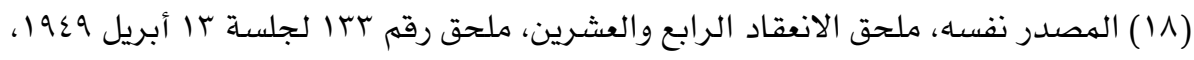

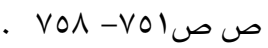

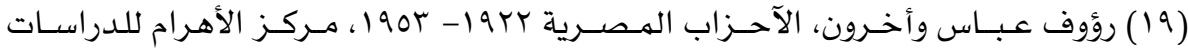

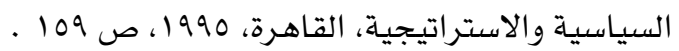

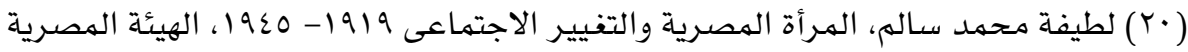

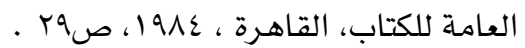

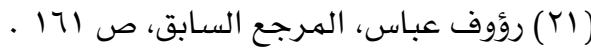

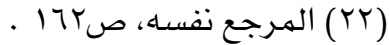

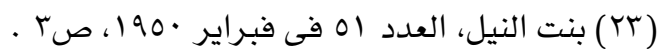

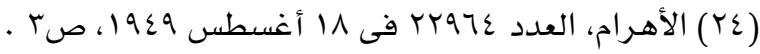

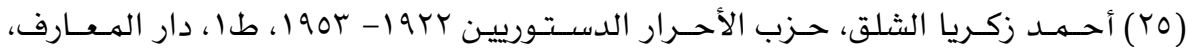

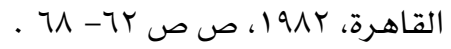

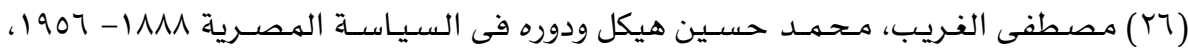

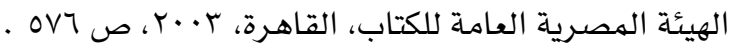

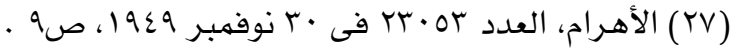

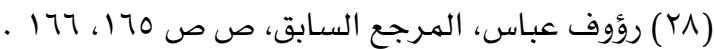

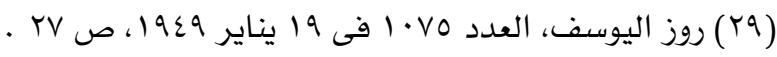

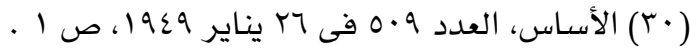

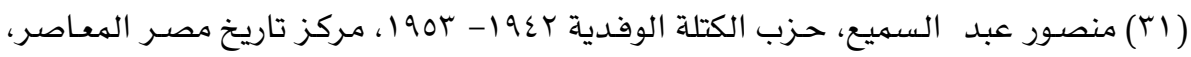

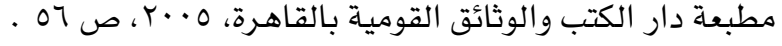

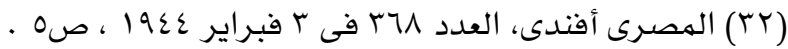

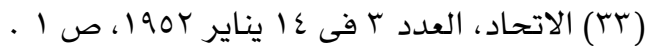

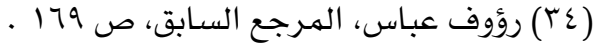

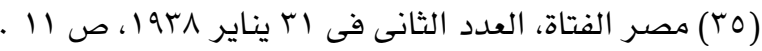

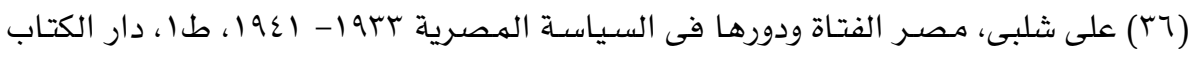

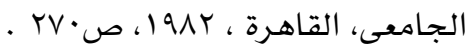

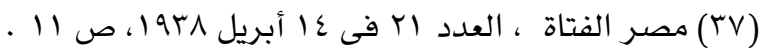

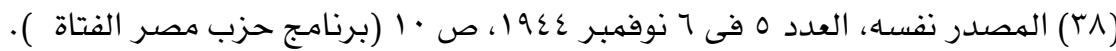

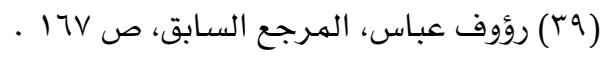

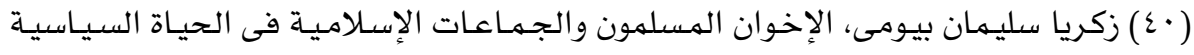

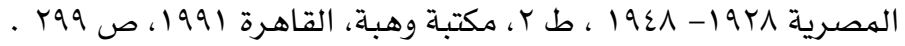




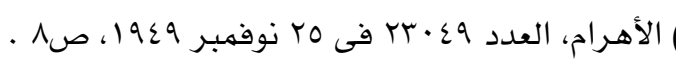

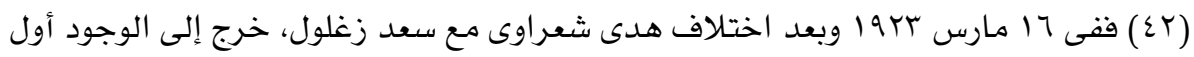

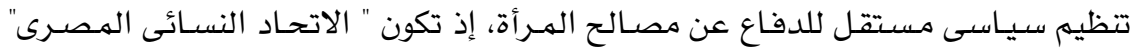

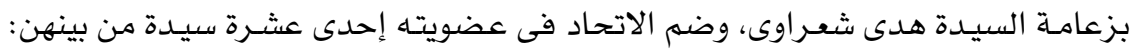

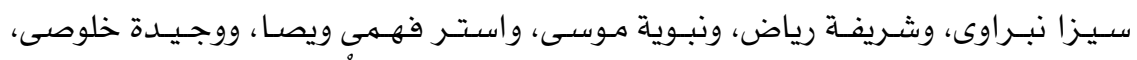

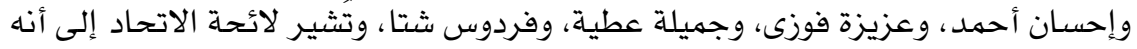

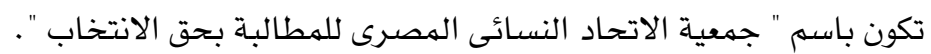

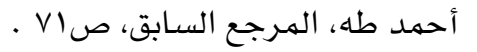

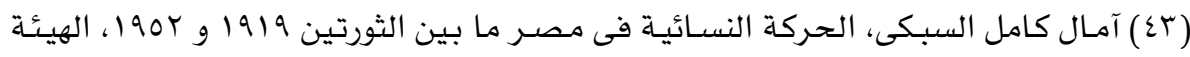

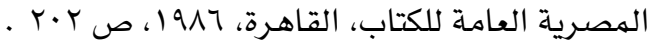

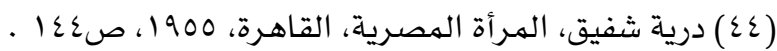

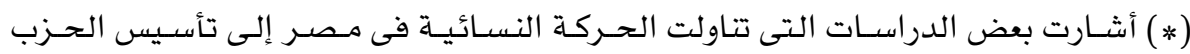

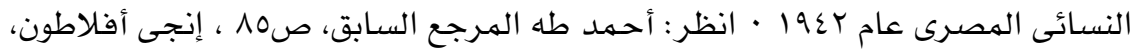

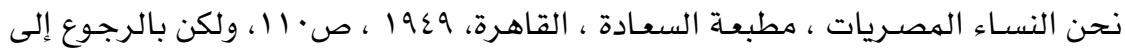

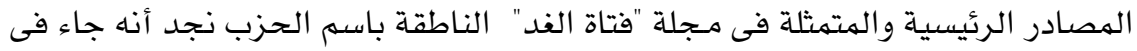

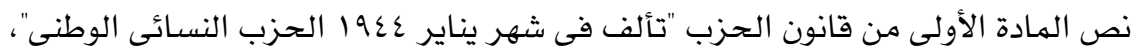

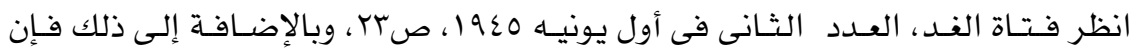

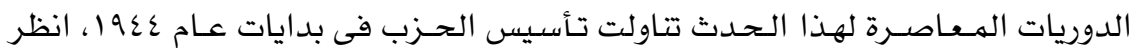

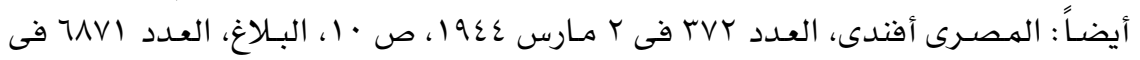

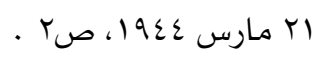

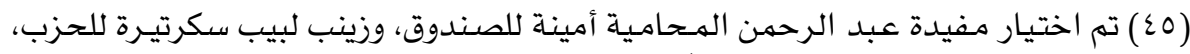

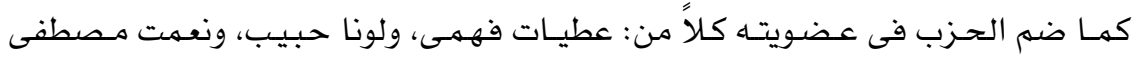

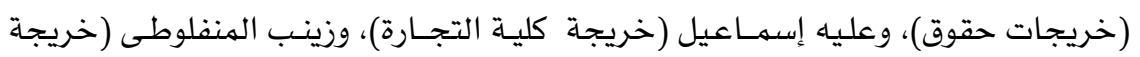

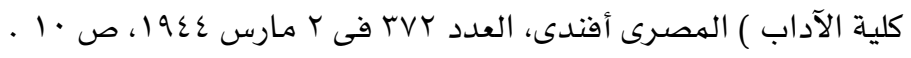

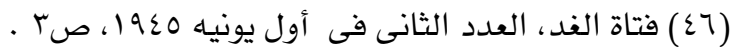

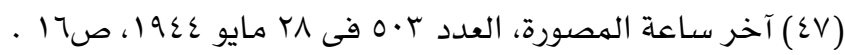

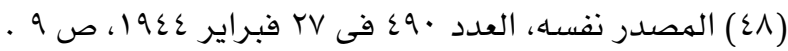

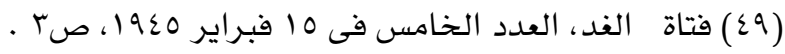

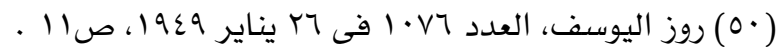

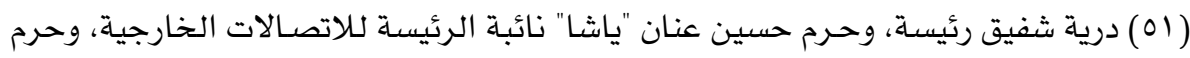

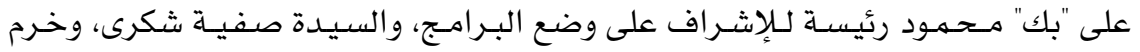


حسين "باشـا" فائق لأمانة الصندوق، والأستاذة زينب لبيب للأمانة العامـة، أمـا العضوية

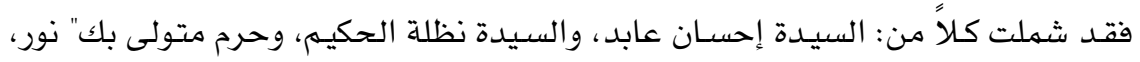

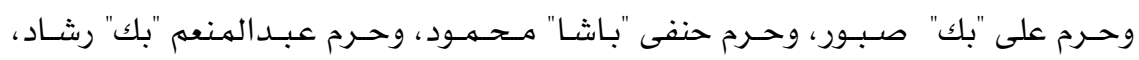

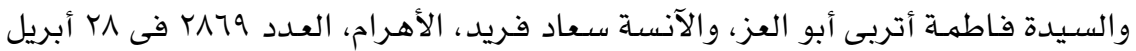
. 7 (19 199

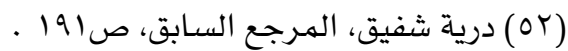

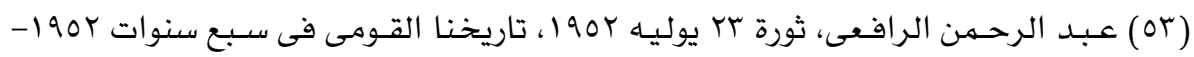

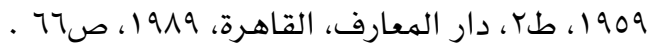

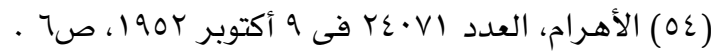

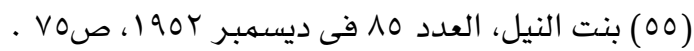

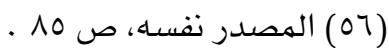

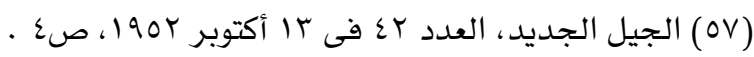

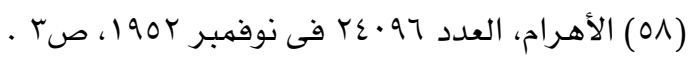

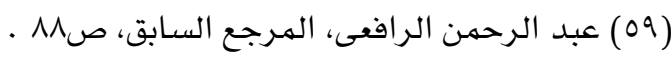

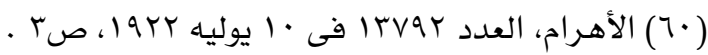

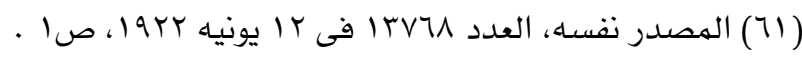

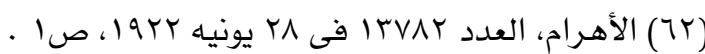

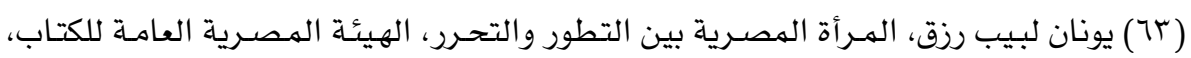

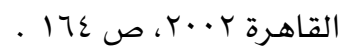

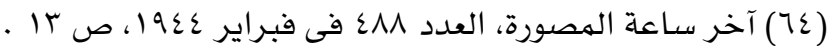

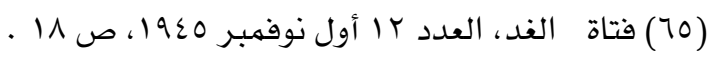

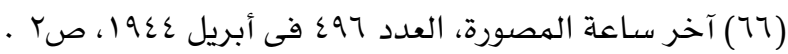

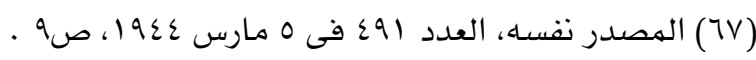

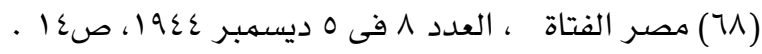

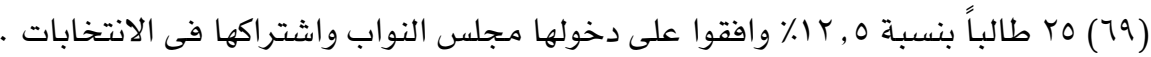

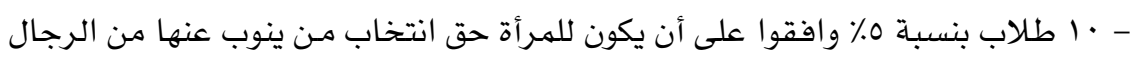

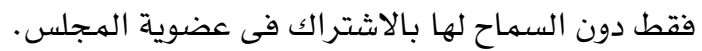

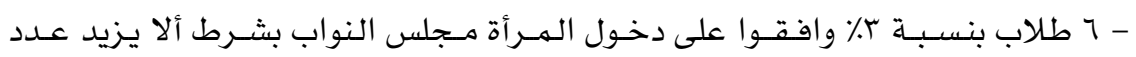

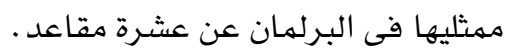

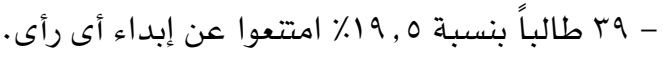

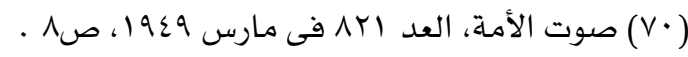




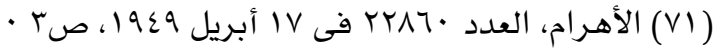

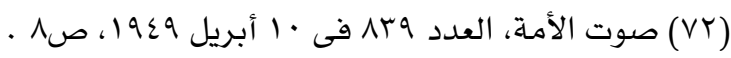

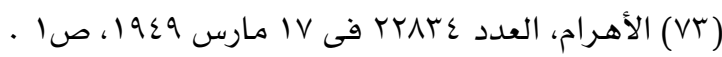

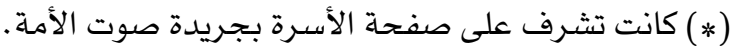

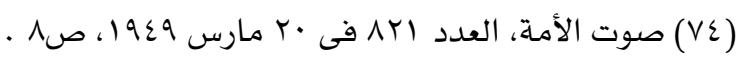

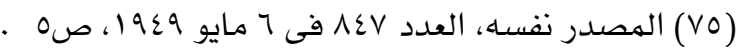

(V7)

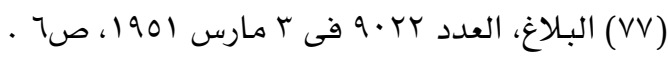

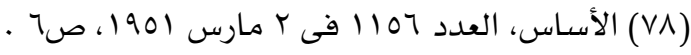

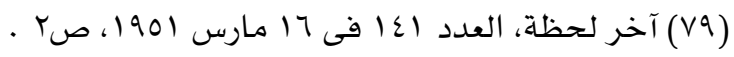

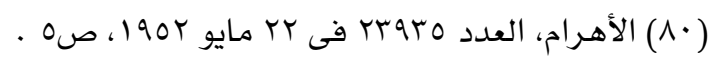

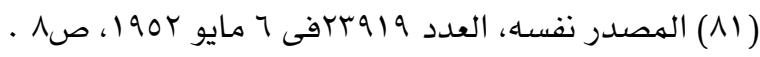

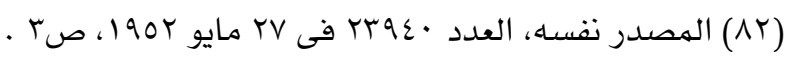

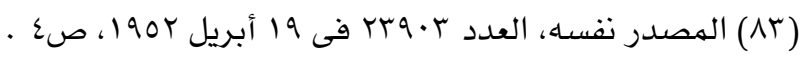

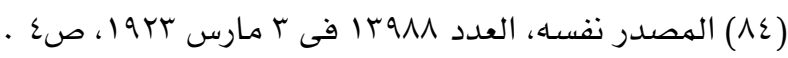

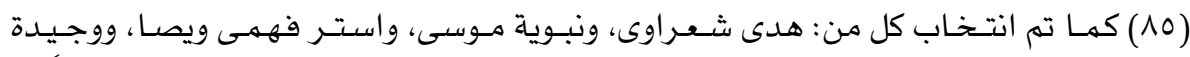

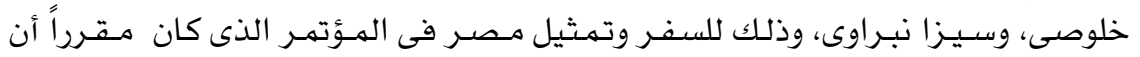

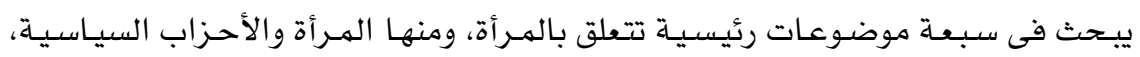

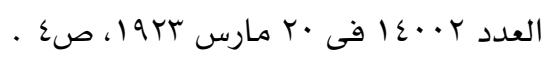

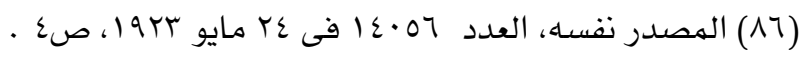

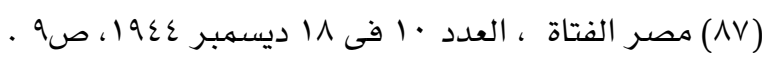

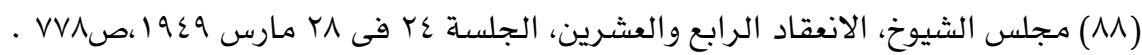

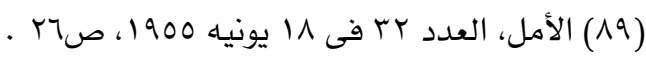

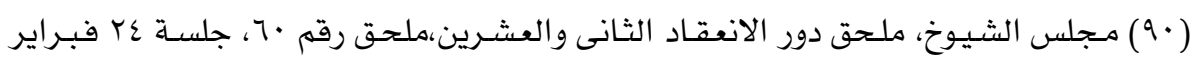

$$
\text { . 11179 19عV }
$$

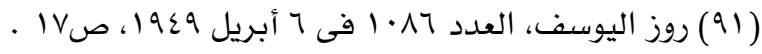

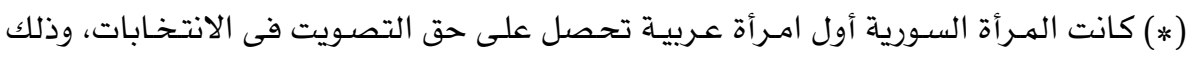

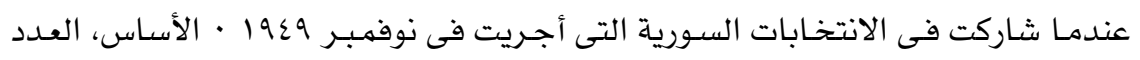

$$
\text { الا }
$$

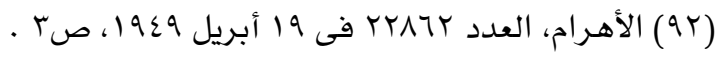

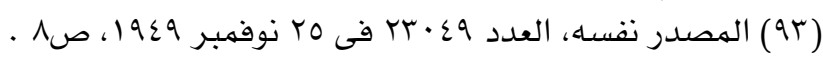

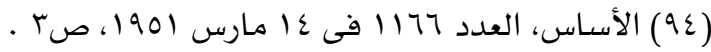




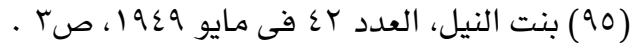

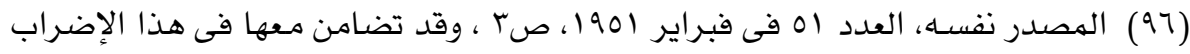

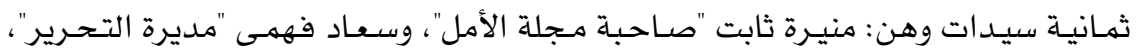

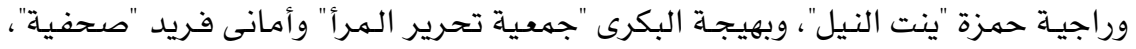

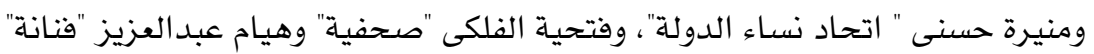

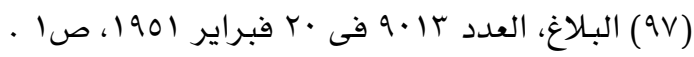

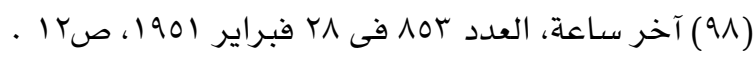

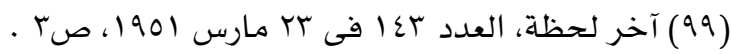

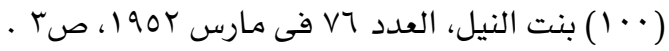

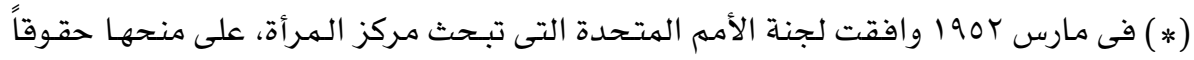

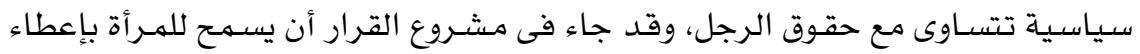

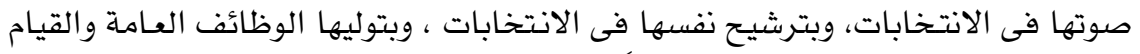

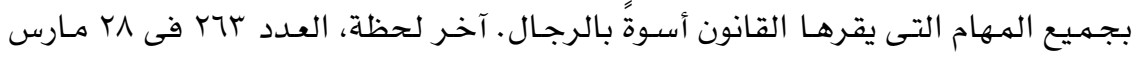

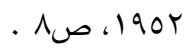

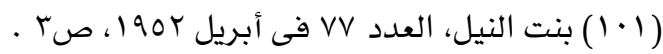

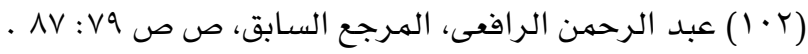

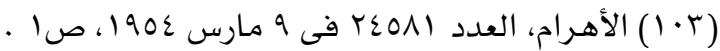

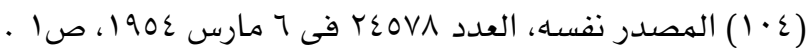

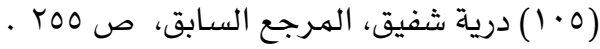

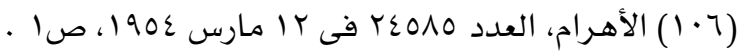

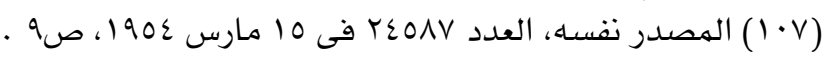

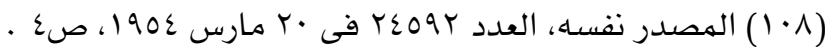

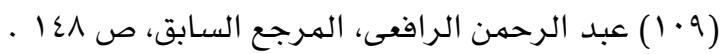

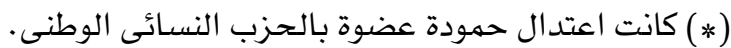

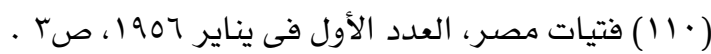

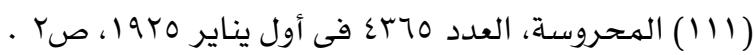

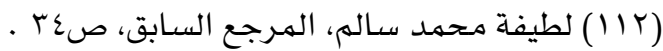

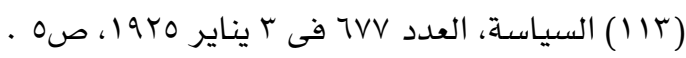

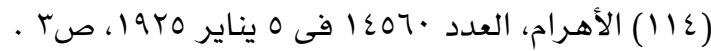

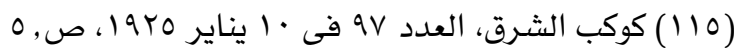

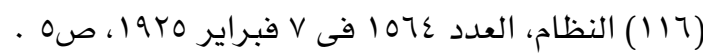

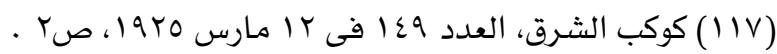




$$
\text { (111) (119) الأهل، العدد (119) }
$$

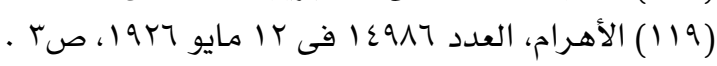

Royal institute of international Affairs, op. cit, p.21. (1 1 .

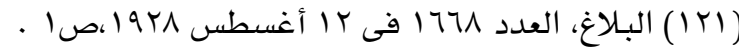

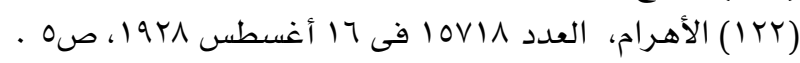

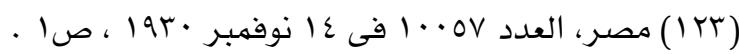

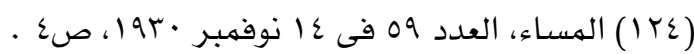

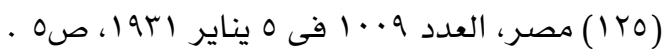

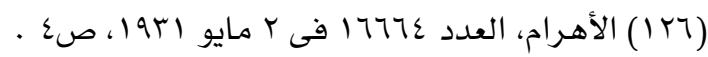

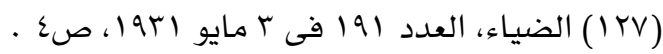

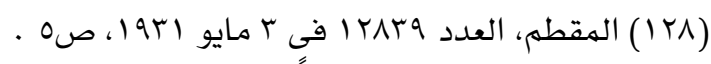

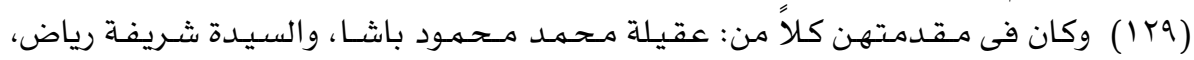

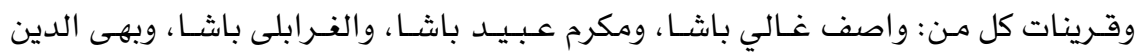

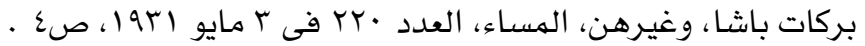

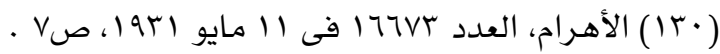

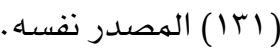

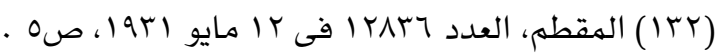

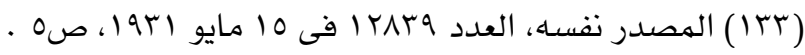

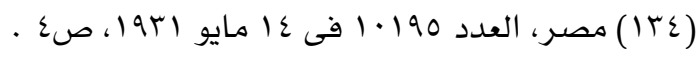

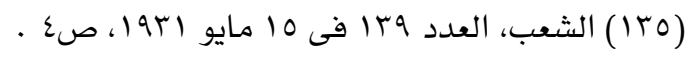

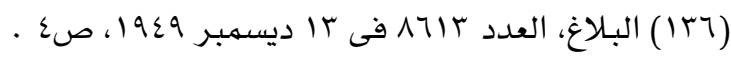

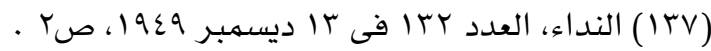

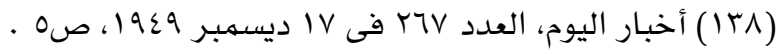

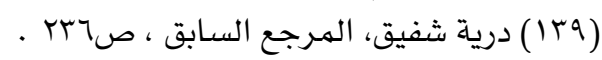

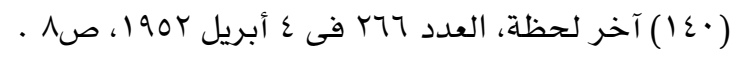

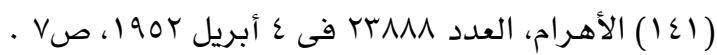

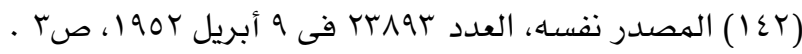

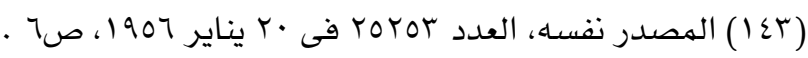

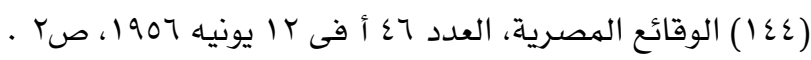

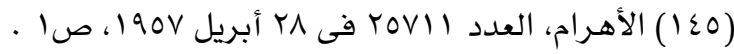

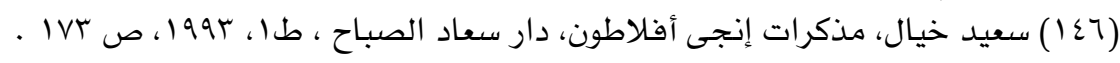

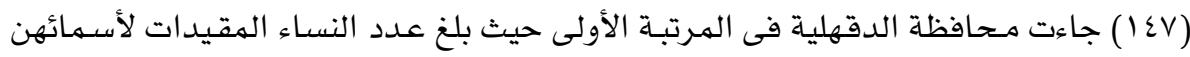




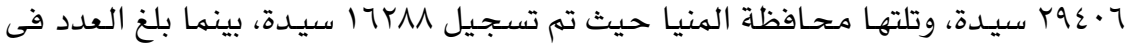

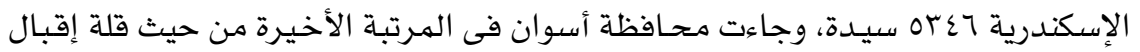

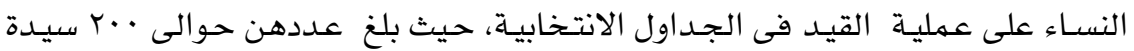

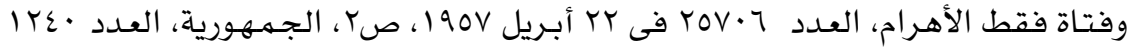

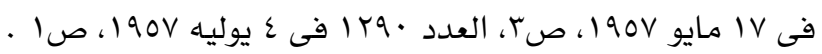

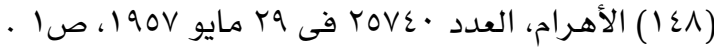

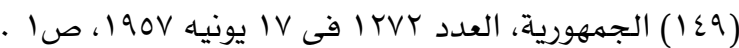

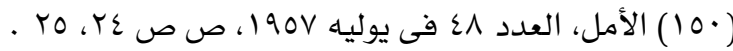
(101) (101) (المصدر نفسـه (101)

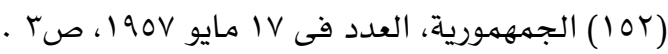

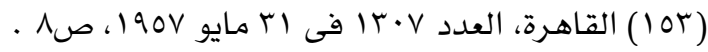

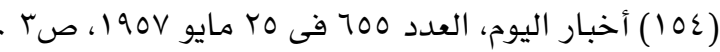

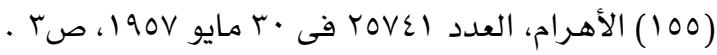

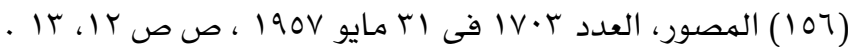

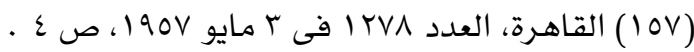

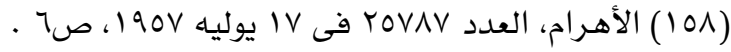

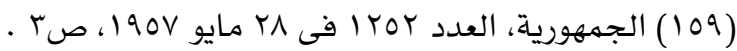

• (17•) (17) (17) المصدر (17)

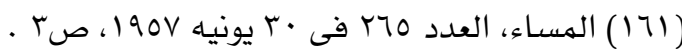

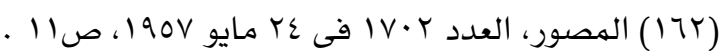

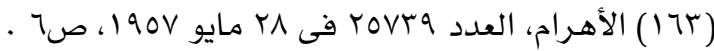

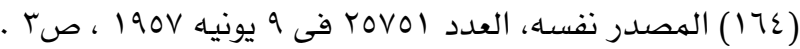

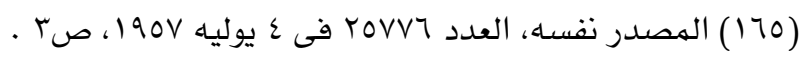

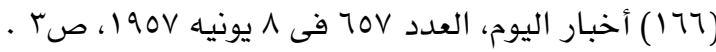

( المصدر نقسيسه (17V)

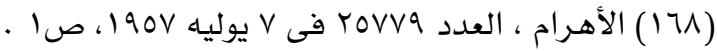

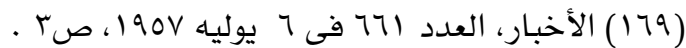

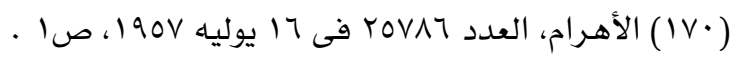




\section{المصادر والهـراجـع \\ أولاً: الوثائق العربية غير المنشورة :

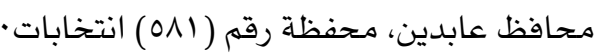

$$
\text { ثانياً : الوثائق العربية المنشورة: مجنطي }
$$

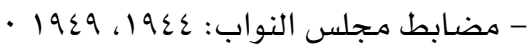

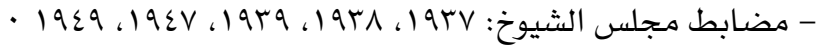

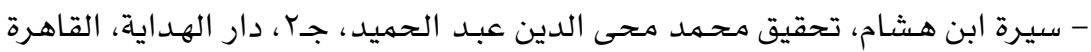

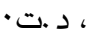

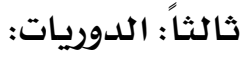

• الاتحساد:

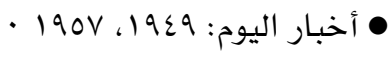

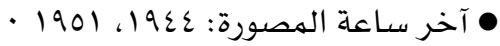

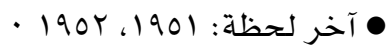

•

• الأمل : 1947، 190V، 1900، 1900،

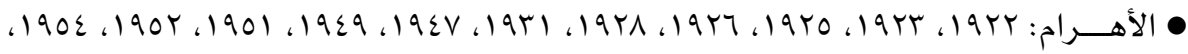

- 190V، 1907

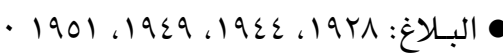

•

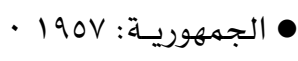

• (190r الجيل الجديد

• روز اليوسف: 19 • 19 •

• السياسـة : 19 •

• الشعب: الشياسك:

• صـوت الأمة : 19 • 199

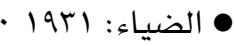

• فتاة الغد: 1920

• فتيات مصسر: 1907 •

• القاهـرة: 190V

• كوكب الشرق: 19ro

• المحروسية: 19 19 


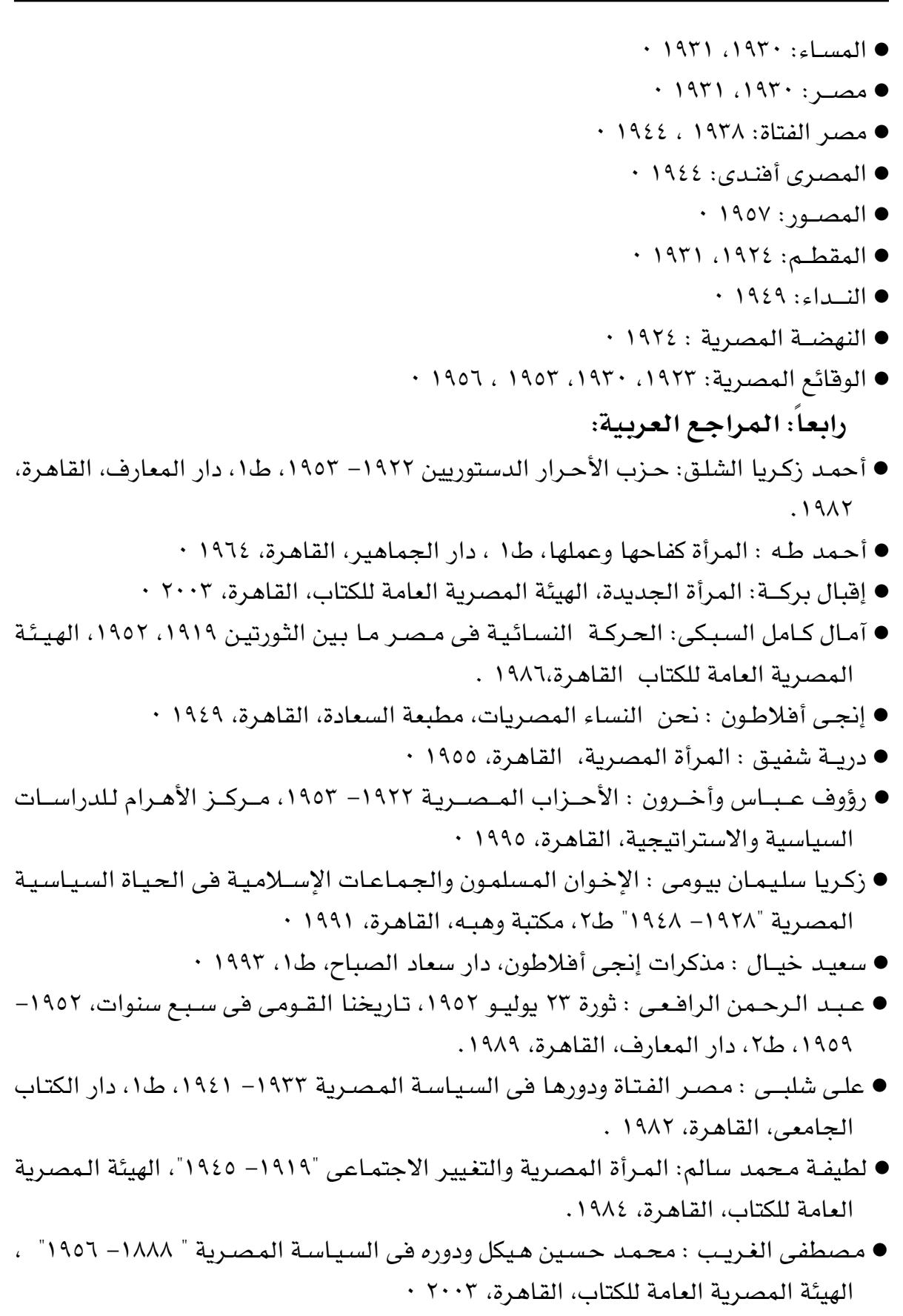




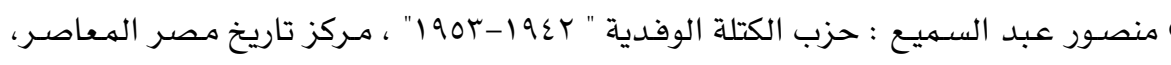

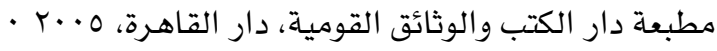

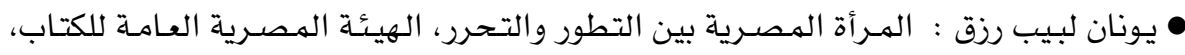

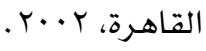

\section{خامساً: المراجع الأجنبية:}

Roya1 institute of international Affairs, Great Britain and Egypt 1914-1915,

London, 1957. 